\title{
Copper-catalyzed three component system for arylsulfenylation of imidazopyridines with elemental sulfur
}

Chitrakar Ravi, N. Naresh Kumar Reddy, Venkatanarayana Pappula, Supravat Samanta and Subbarayappa Adimurthy*

Academy of Scientific \& Innovative Research, CSIR-Central Salt \& Marine Chemicals Research Institute, G.B. Marg, Bhavnagar-364 002. Gujarat (INDIA)

e-mail: adimurthy@csmcri.org

\section{Table of Contents}

\begin{tabular}{|l|l|l|}
\hline S.No & \begin{tabular}{l} 
Page number \\
\hline 1 \\
molecules
\end{tabular} & S2 \\
\hline 2 & Crystal thermal ellipsoid plot & S3 \\
\hline 3 & $\begin{array}{l}\text { Crystal Data and Refinement } \\
\text { Parameters }\end{array}$ & S4-S5 \\
\hline 4 & ${ }^{1} \mathrm{H} \&{ }^{13} \mathrm{C}-$ NMR Spectra of all products & S6-S35 \\
\hline 5 & HRMS of new compounds & S36-S42 \\
\hline
\end{tabular}


1. Imidazo[1,2-a]pyridine-based molecules

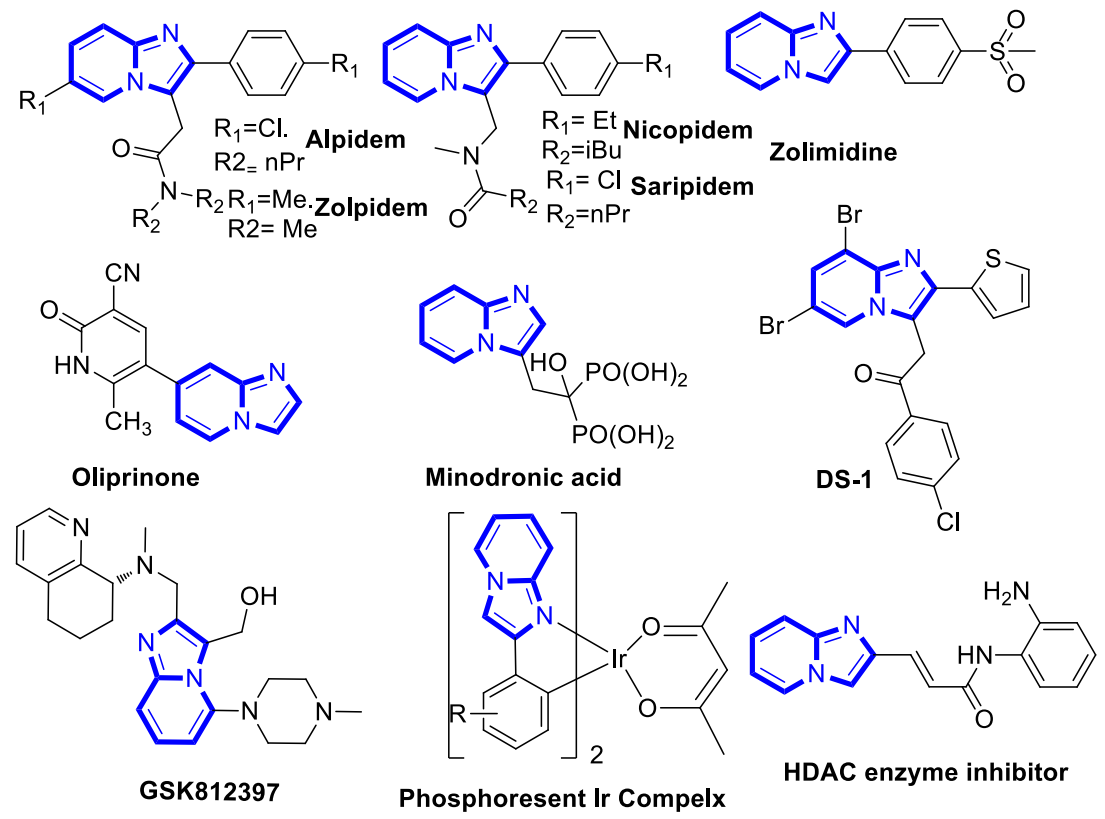

Figure S1. Imidazo[1,2-a]pyridine-based molecules 
2. Thermal ellipsoid plot for the crystal structure 4n

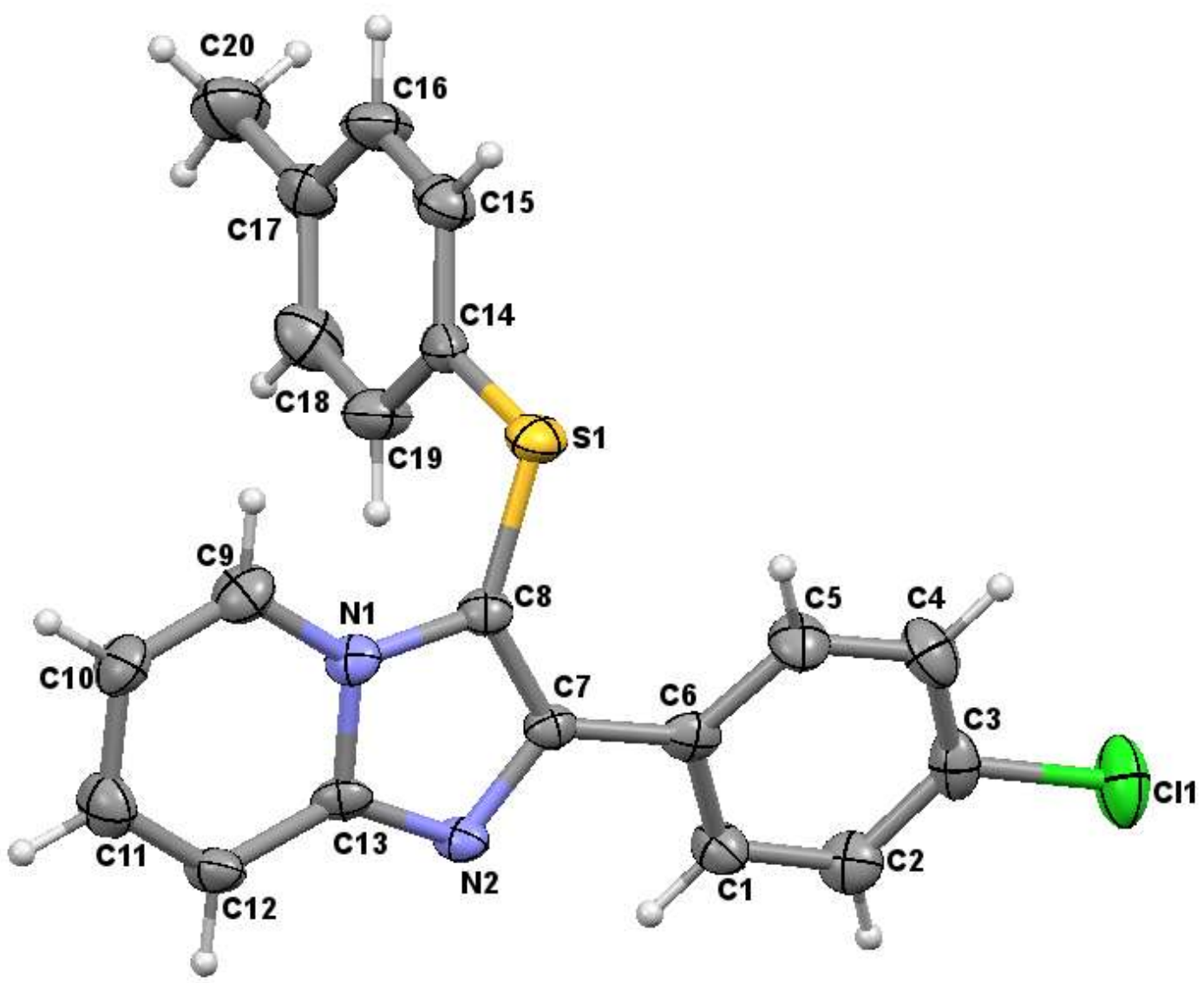

Thermal ellipsoid plot for the compound $4 \mathbf{n}$ with atom numbering scheme (40\% probability factor for the thermal ellipsoids) 


\section{Crystal Data and Refinement Parameters}

Experimental : X-ray part

Crystal of suitable size was selected for the organic compound, immersed in partone oil and then mounted on the tip of a glass fiber using epoxy resin. Intensity data for all four crystals were collected at $100 \mathrm{~K}$ using graphite monochromatised $\operatorname{MoK}_{\alpha}(\lambda=0.71073 \AA)$ radiation on diffractometer equipped with $\mathrm{CCD}$ area detector. The data integration and reduction were processed. ${ }^{1}$ An empirical absorption correction was applied to the collected reflections. ${ }^{2}$ The structures were solved by direct methods ${ }^{3}$ and refined on $F^{2}$ by the full-matrix least-squares technique ${ }^{4}$ package. Graphics are generated. ${ }^{5,6}$ Non-hydrogen atoms were refined anisotropically till convergence is reached and the hydrogen atoms of the organic compound is stereochemically fixed. Crystallographic parameters for the compound is given in Table S1.

1. Sheldrick, G. M.; SAINT 5.1 ed.; Siemens Industrial Automation Inc.: Madison, WI, 1995.

2. SADABS, Empirical Absorption Correction Program; University of Göttingen: Göttingen, Germany 1997.

3. Sheldrick, G. M.; SHELXTL Reference Manual: Version 5.1; Bruker AXS: Madison, WI 1997.

4. Sheldrick, G.M. SHELXL-97: Program for Crystal Structure Refinement; University of Göttingen: Göttingen, Germany (1997).

5. A.L.Spek, Acta Cryst. 2009, D65, 148-155

6. Mercury 1.3, Supplied with Cambridge Structural Database; CCDC: Cambridge, U.K., (2003). 
Table S1. Crystal Data and Refinement Parameters for Compounds $4 \mathbf{n}$

\begin{tabular}{|c|c|}
\hline Identification code & $4 n$ \\
\hline Chemical formula & $\mathrm{C}_{20} \mathrm{H}_{15} \mathrm{~N}_{2} \mathrm{Cl} \mathrm{S}$ \\
\hline Formula weight & 350.85 \\
\hline Crystal Colour & Colourless \\
\hline Crystal Size (mm) & $0.28 \times 0.10 \times 0.06$ \\
\hline Temperature (K) & $150(2)$ \\
\hline Crystal System & Monoclinic \\
\hline Space Group & $\mathrm{P} 21 / \mathrm{n}$ \\
\hline $\mathrm{a}(\AA)$ & $12.126(10)$ \\
\hline $\mathrm{b}(\AA)$ & $5.863(5)$ \\
\hline$c(\AA)$ & $24.164(19)$ \\
\hline$\alpha\left(^{\circ}\right)$ & 90 \\
\hline$\beta\left({ }^{\circ}\right)$ & $103.359(13)$ \\
\hline$\gamma\left({ }^{\circ}\right)$ & 90 \\
\hline $\mathrm{Z}$ & 4 \\
\hline $\mathrm{V}\left(\AA^{3}\right)$ & $1672(2)$ \\
\hline Density $\left(\mathrm{Mg} / \mathrm{m}^{3}\right)$ & 1.394 \\
\hline$\mu\left(\mathrm{mm}^{-1}\right)$ & 0.356 \\
\hline $\mathrm{F}(000)$ & 728 \\
\hline Reflections Collected & 7671 \\
\hline Independent Reflections & 2925 \\
\hline $\mathrm{R}_{\text {(int) }}$ & 0.0599 \\
\hline Number of parameters & 218 \\
\hline GOF on $\mathrm{F}^{2}$ & 1.179 \\
\hline FinalR1/wR2(I>2 $\sigma(\mathrm{I})$ & $0.0890 / 0.1788$ \\
\hline Weighted R1/wR2 (all data) & $0.1208 / 0.1906$ \\
\hline CCDC number & 1484511 \\
\hline
\end{tabular}




\section{Copies of ${ }^{1} \mathrm{H}$ and ${ }^{13} \mathrm{C}$ NMR spectra}
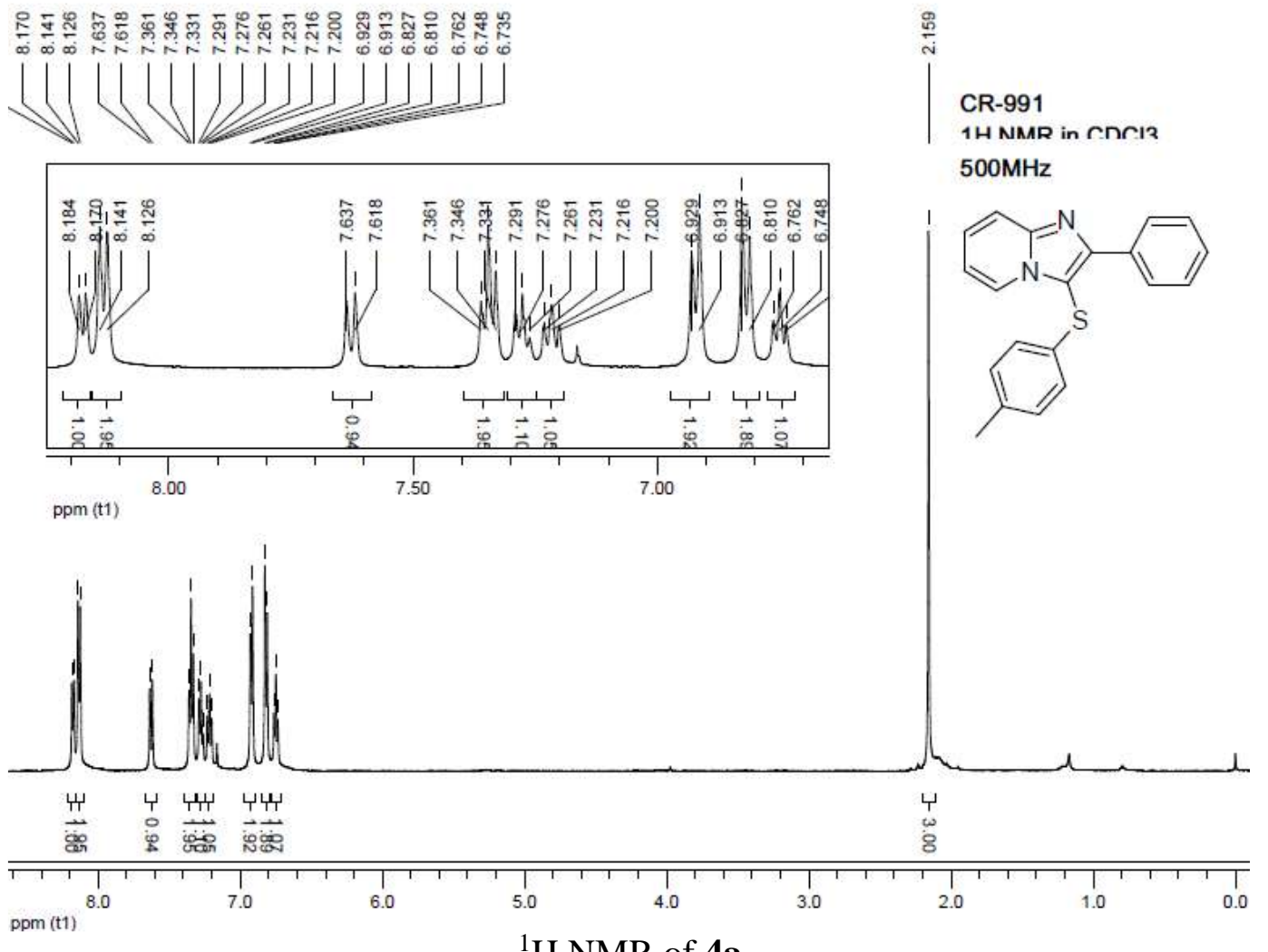

ppm (t1)

${ }^{1} \mathrm{H}$ NMR of $\mathbf{4 a}$

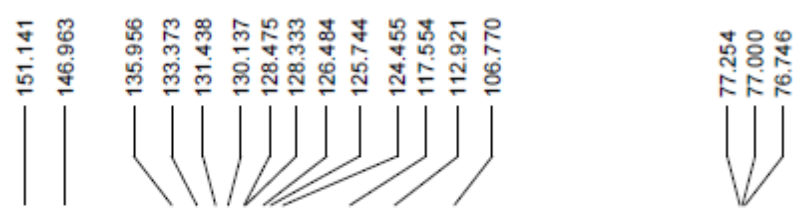

CR-991

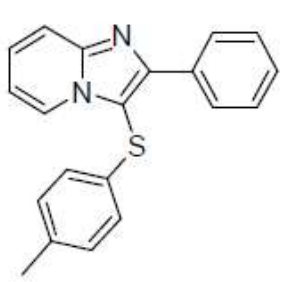

|

13r. NMR in $C . \mathrm{C} .13$

$500 \mathrm{MHz}$

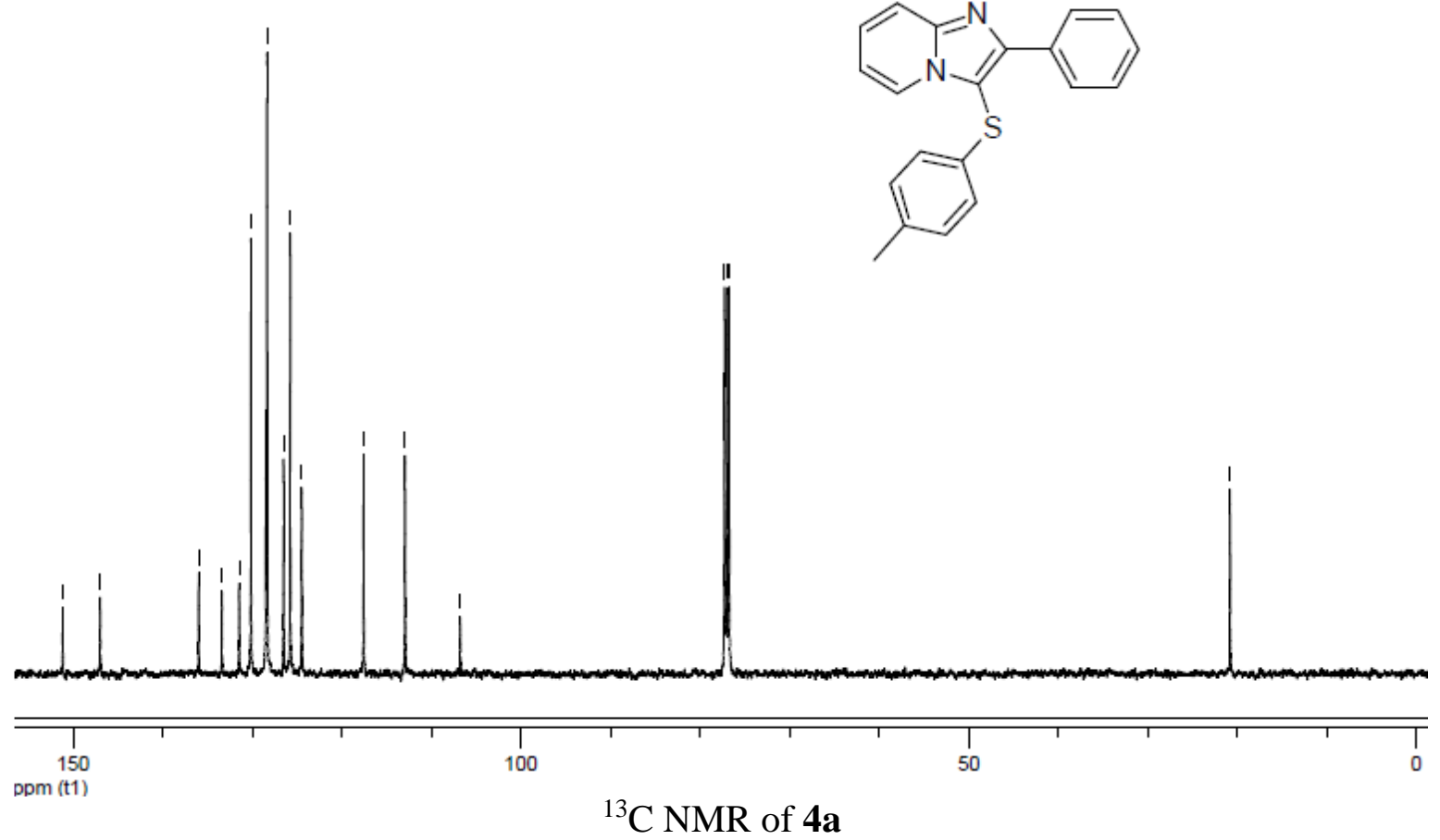




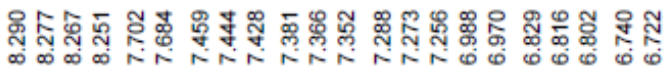

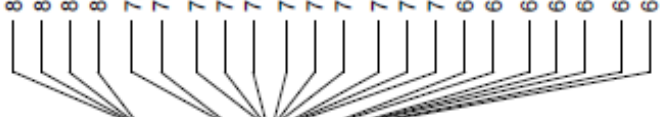

CR-3A

1H NMAR in COCI?

$500 \mathrm{MHz}$
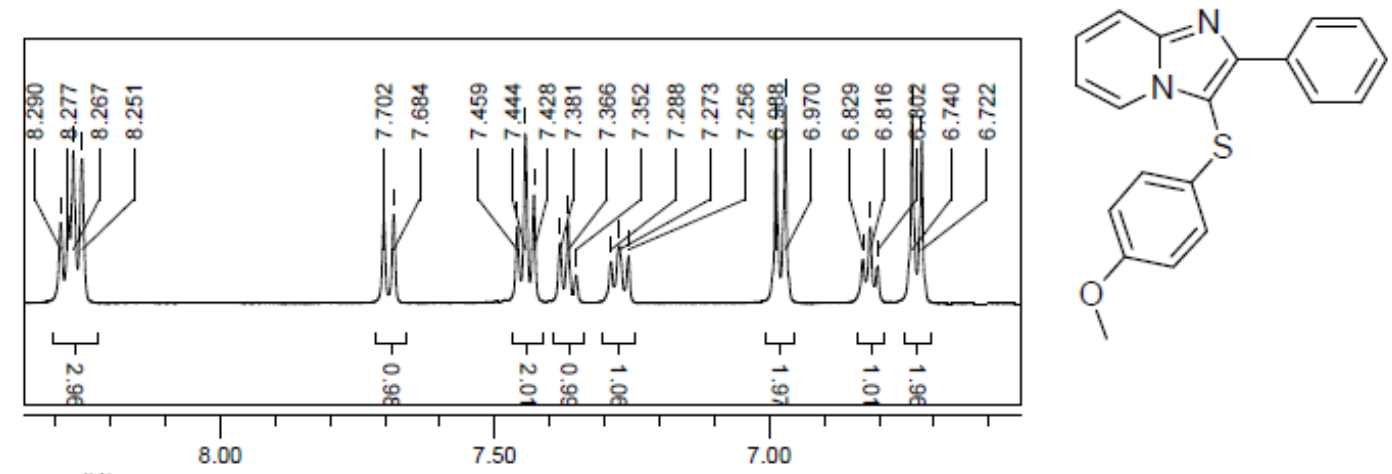

ppm (t1)

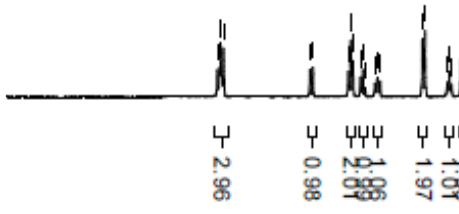

.pm (t1)

${ }^{1} \mathrm{H}$ NMR of $\mathbf{4 b}$
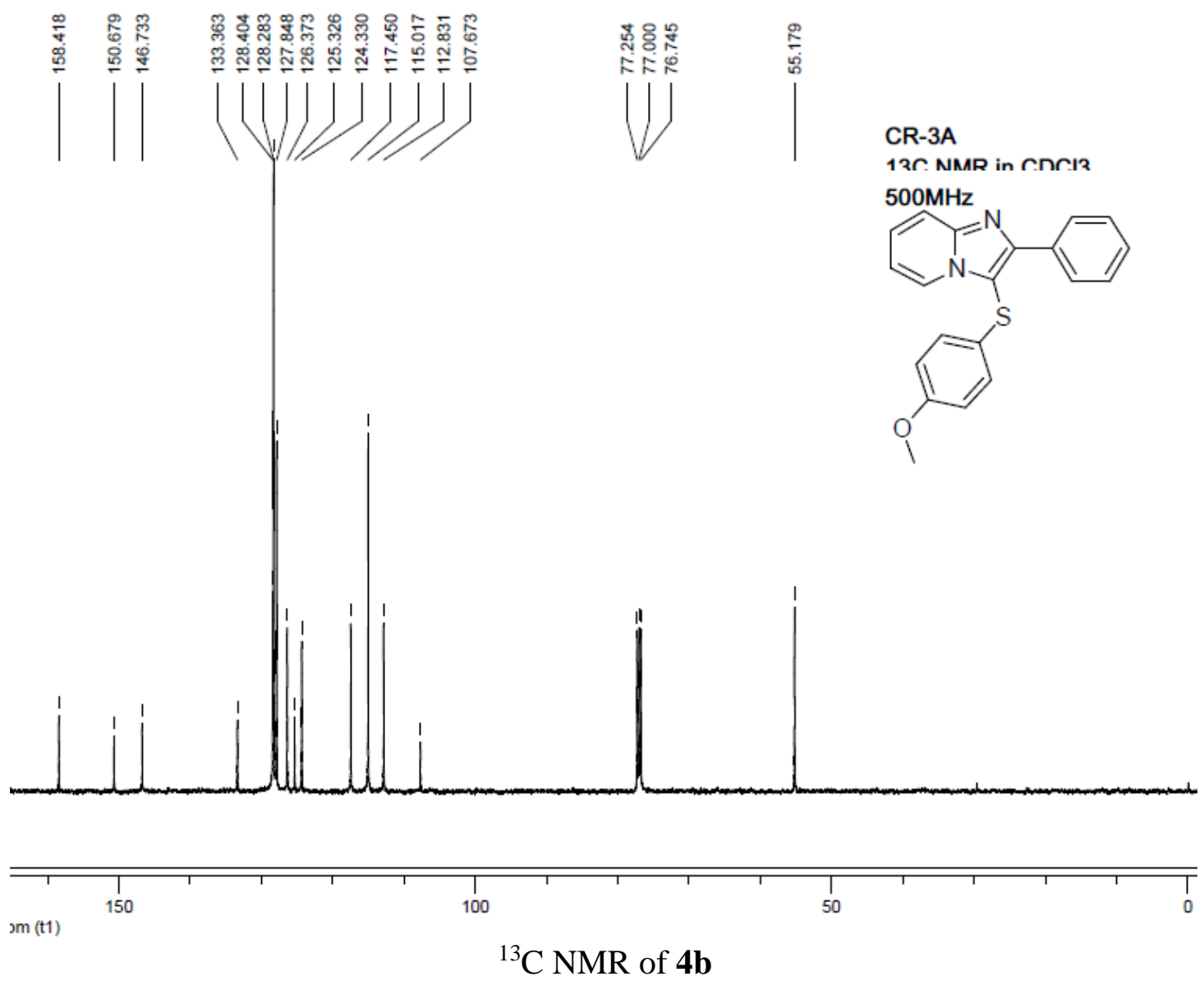


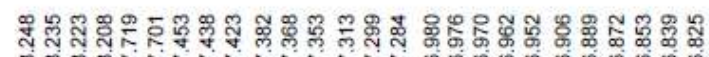

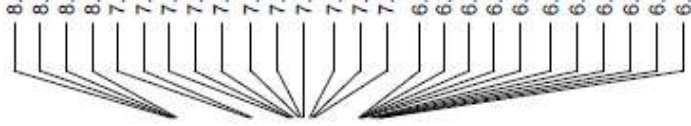

CR-997C

1H NMR in C.NC.I3

$500 \mathrm{MHz}$
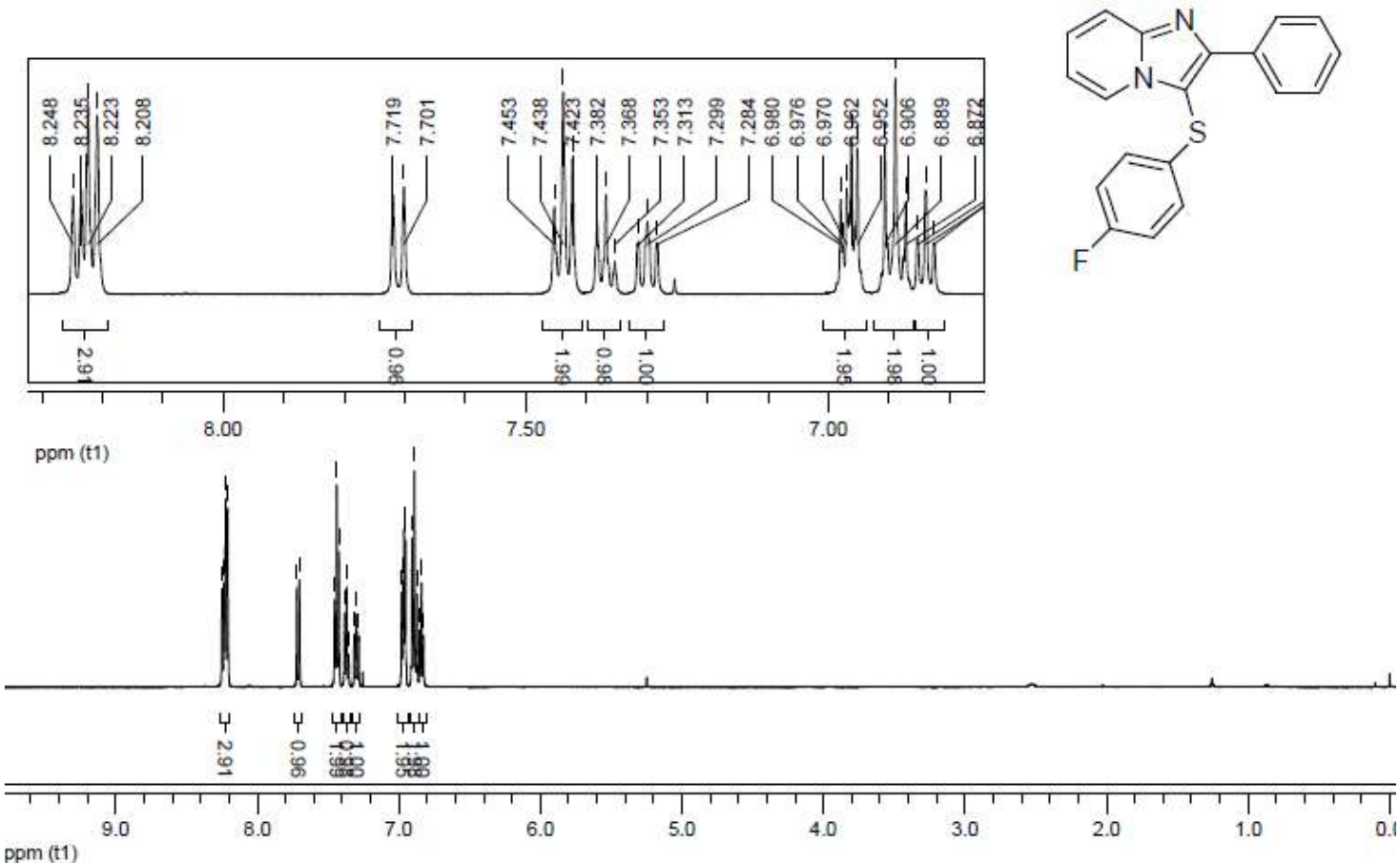

${ }^{1} \mathrm{H}$ NMR of $\mathbf{4 c}$

包年 동

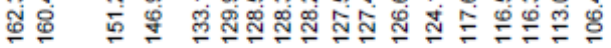

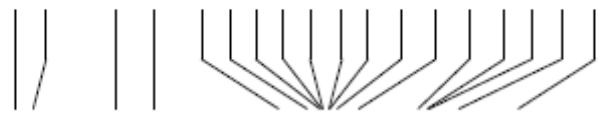

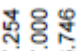

F下i

1)

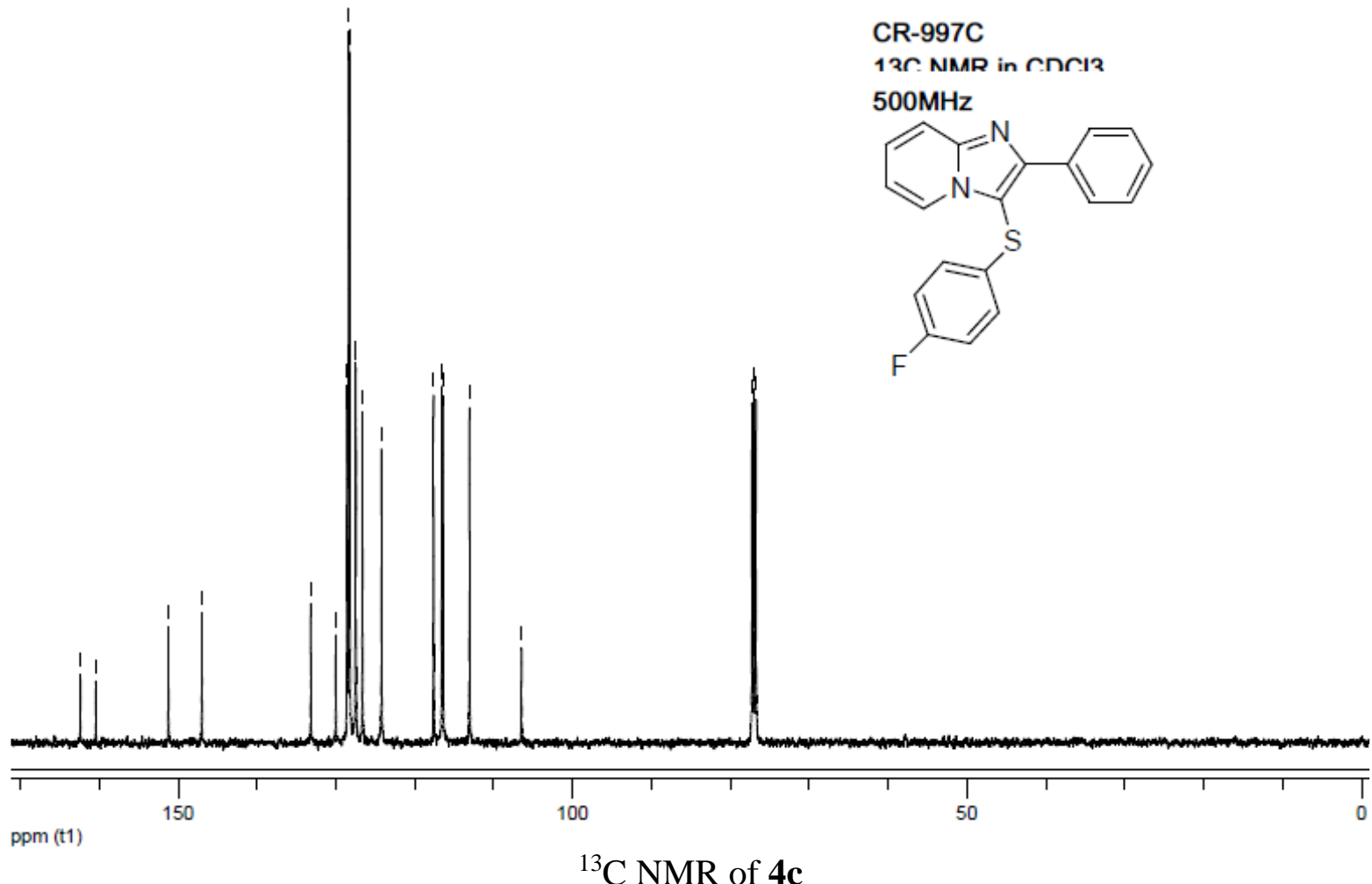




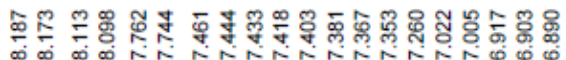
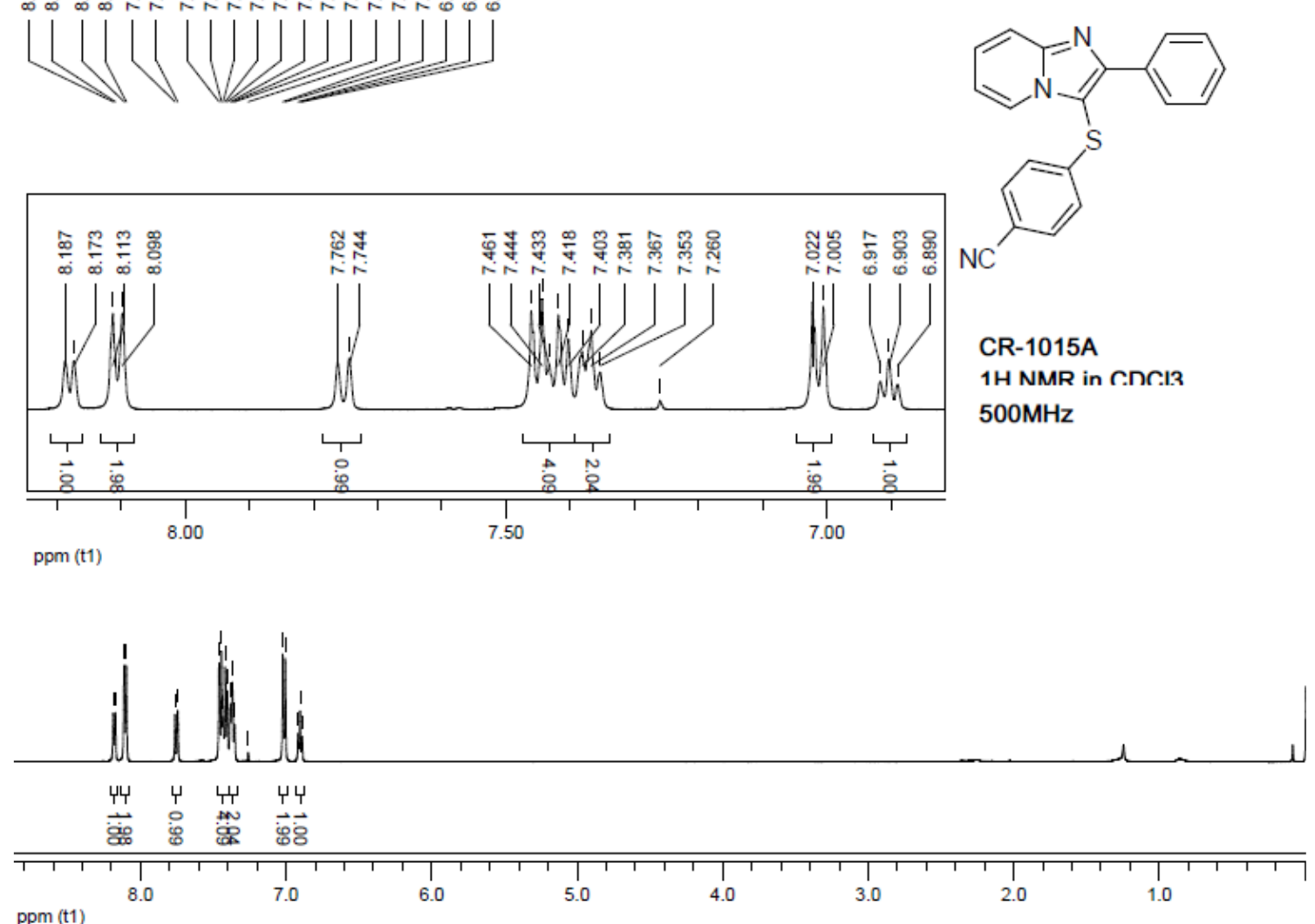

${ }^{1} \mathrm{H}$ NMR of $4 d$
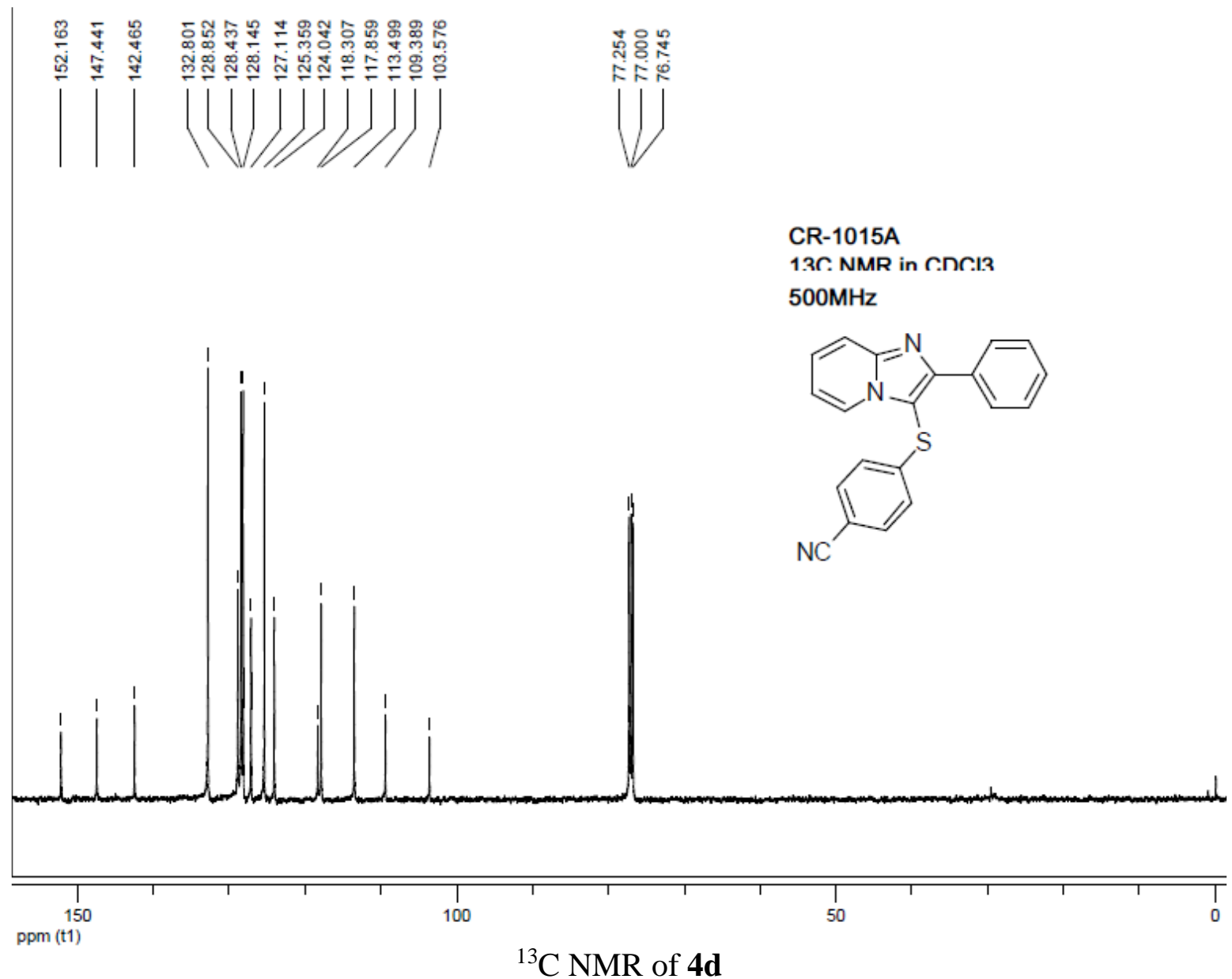

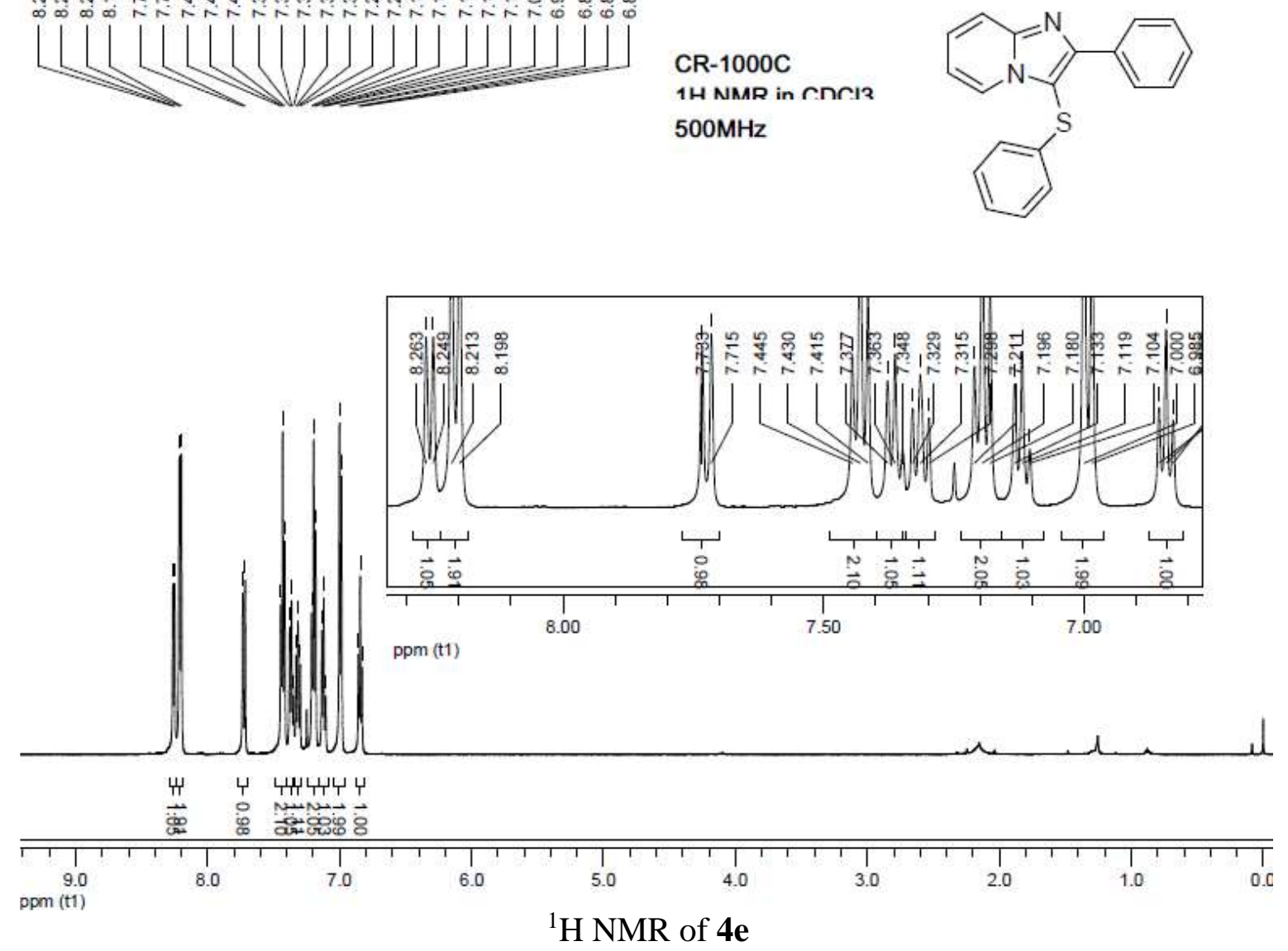

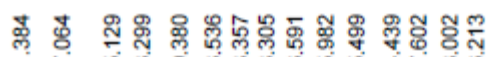

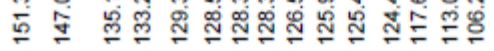
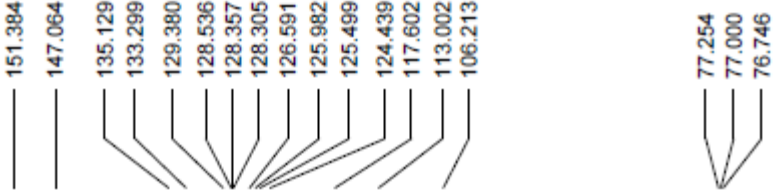

CR-1000C

13C. NMR in C.NC.I3

$500 \mathrm{MHz}$
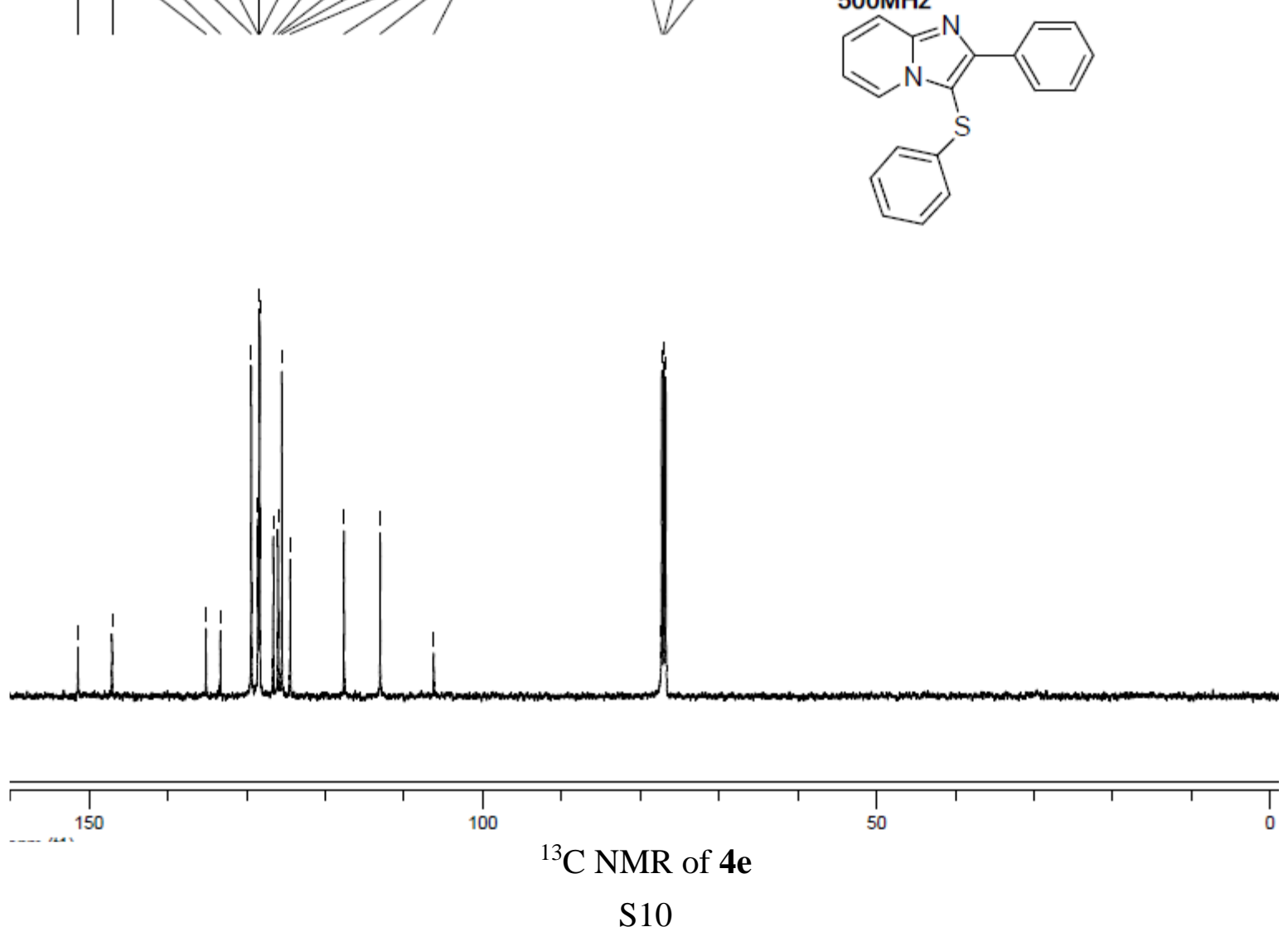


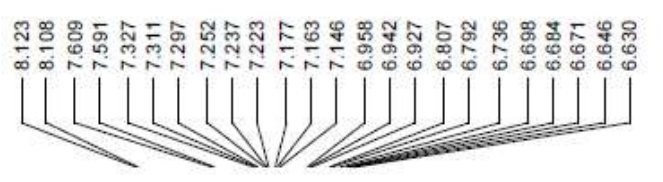

CR-997A
1H NMR in CnC.1
$500 \mathrm{MHz}$

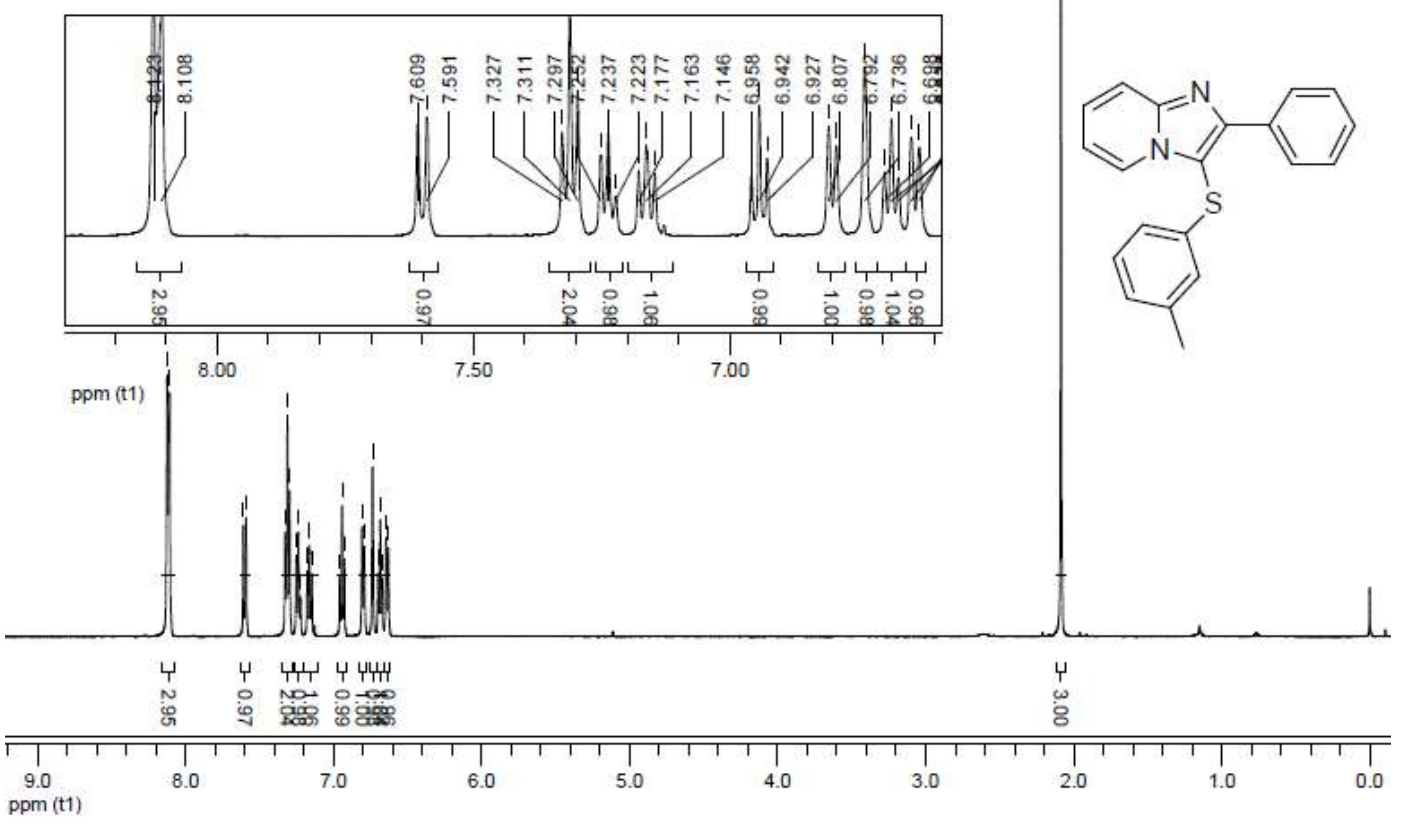

${ }^{1} \mathrm{H}$ NMR of $\mathbf{4 i}$

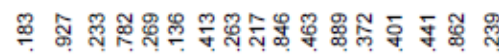

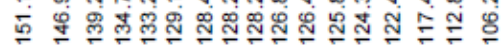
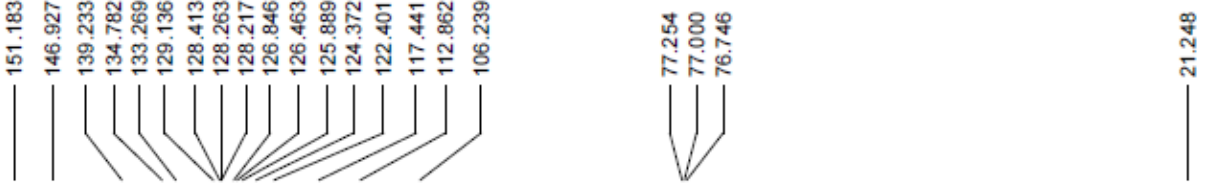

CR-997A

13.. NMR in C.nC.I3

$500 \mathrm{MHz}$
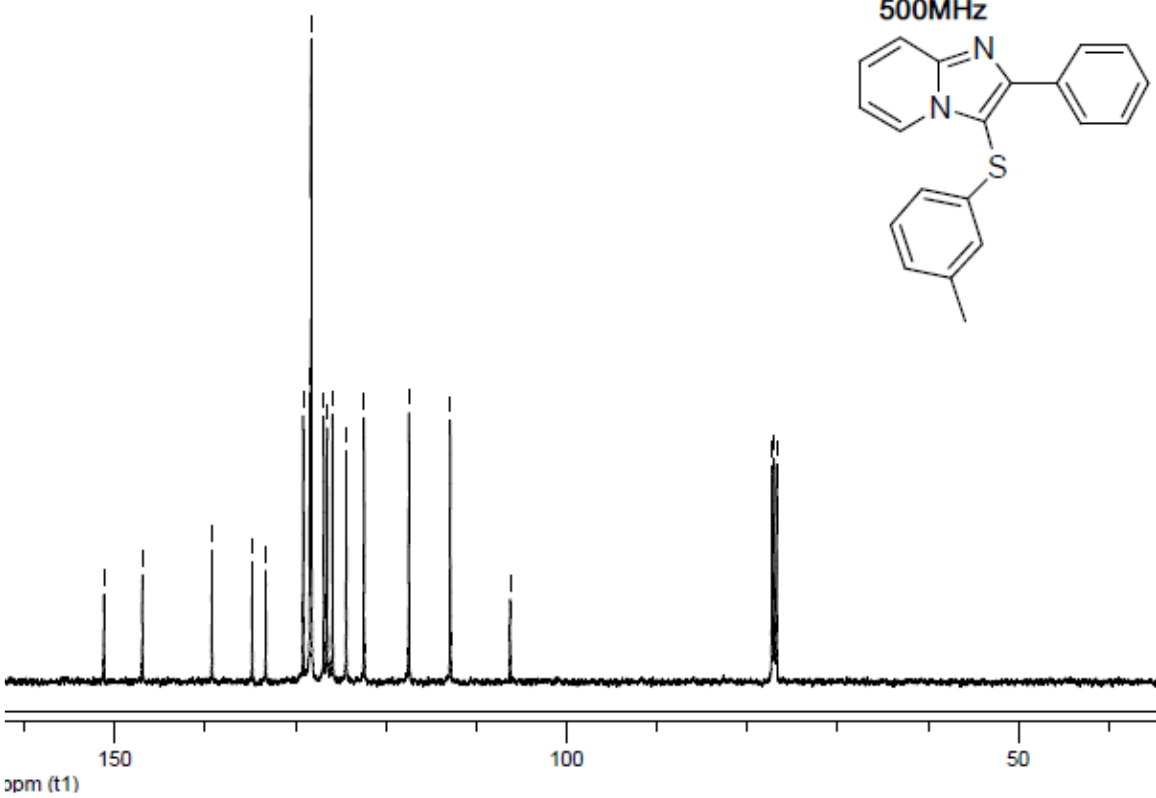

गpm (t1
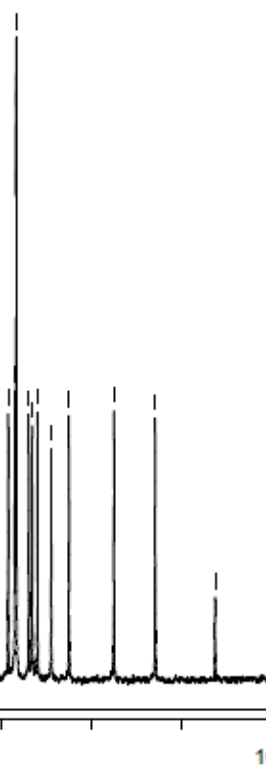

${ }^{13} \mathrm{C}$ NMR of $\mathbf{4 i}$ 


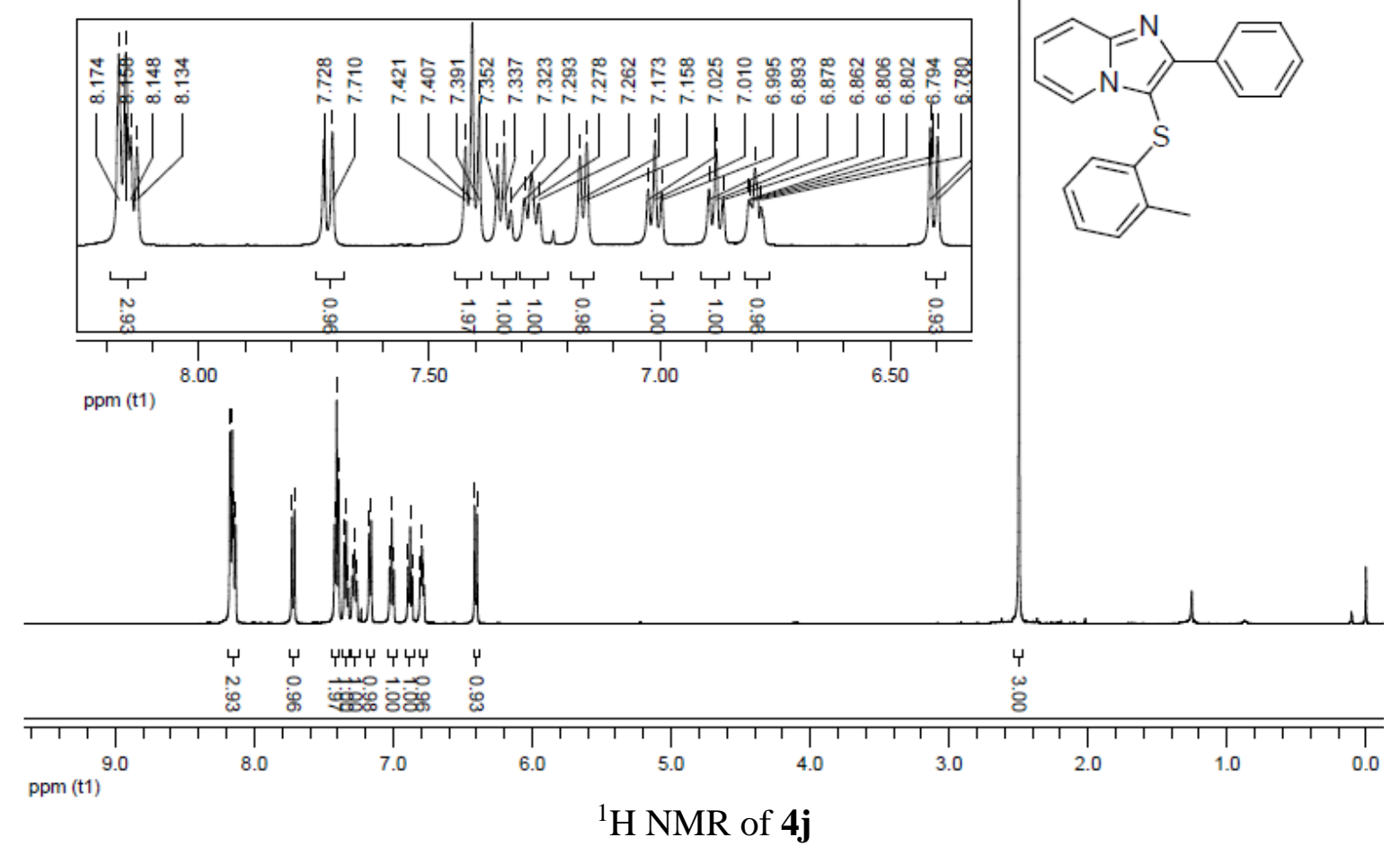

CR-11B

1H NMR in CACIR

$500 \mathrm{MHz}$

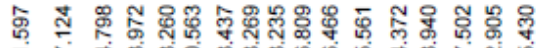

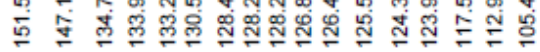
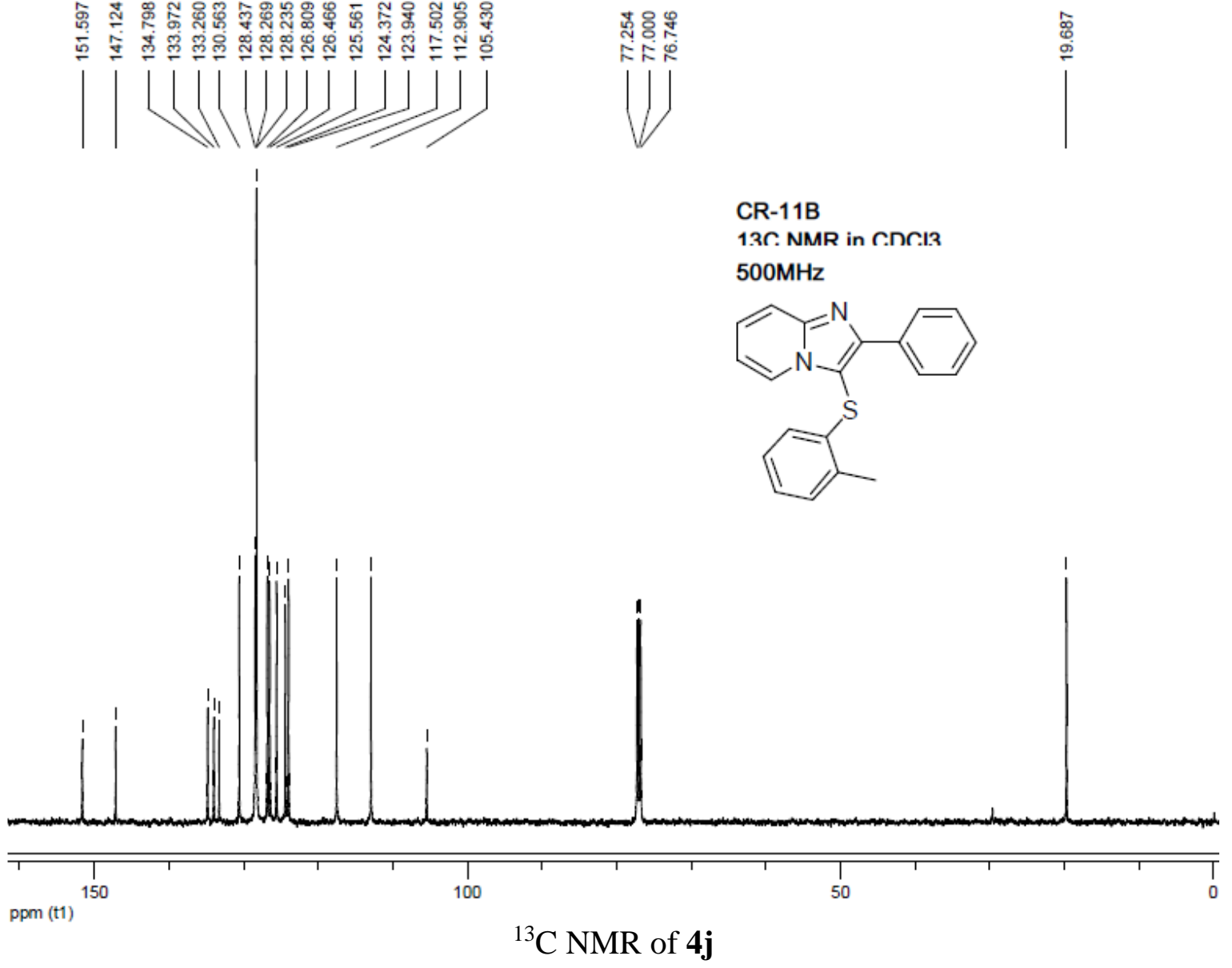

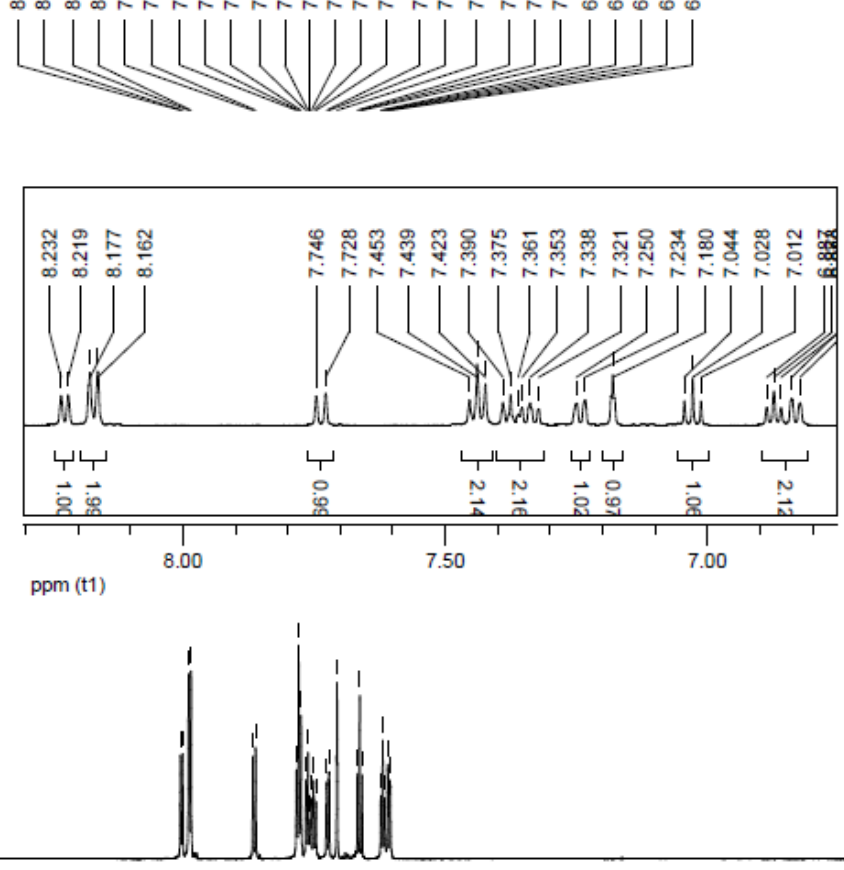

世

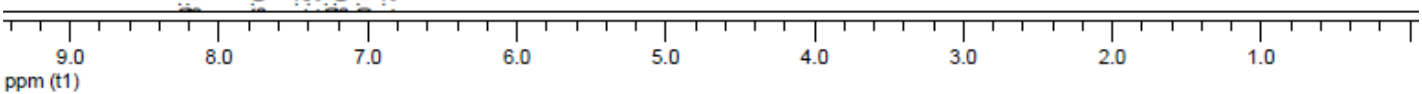

${ }^{1} \mathrm{H}$ NMR of $\mathbf{4 k}$

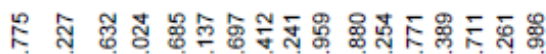

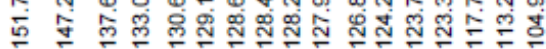
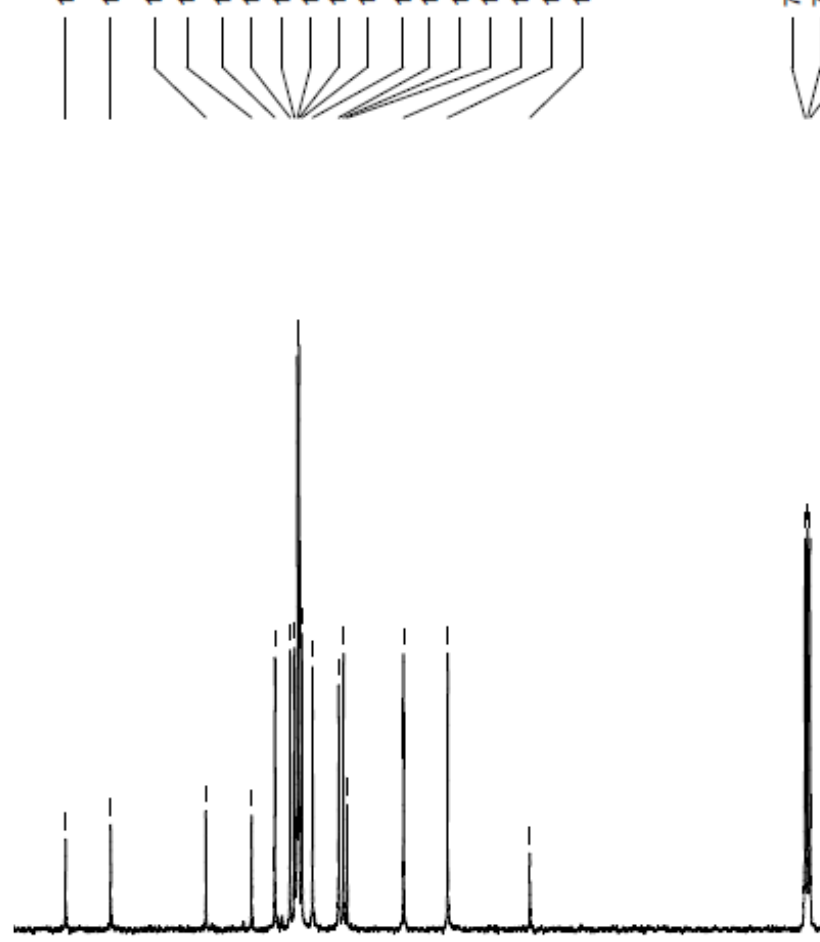

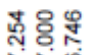

NR

$1 /$

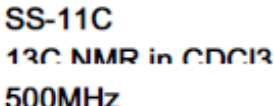

$500 \mathrm{MHz}$

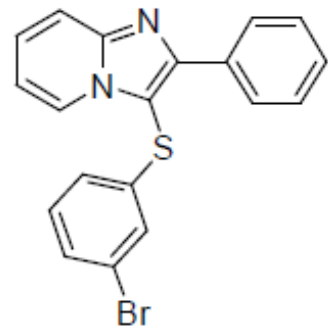

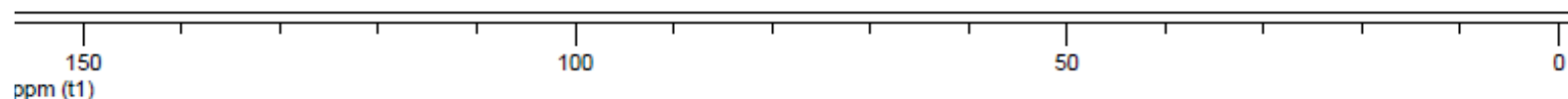


${ }^{13} \mathrm{C}$ NMR of $4 \mathbf{k}$

였였

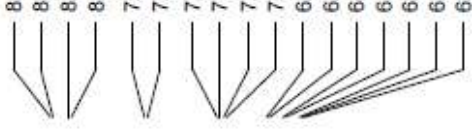

$\bar{్}$ đู

CR-3C

1H NMR in C.NC.I3

$500 \mathrm{MHz}$
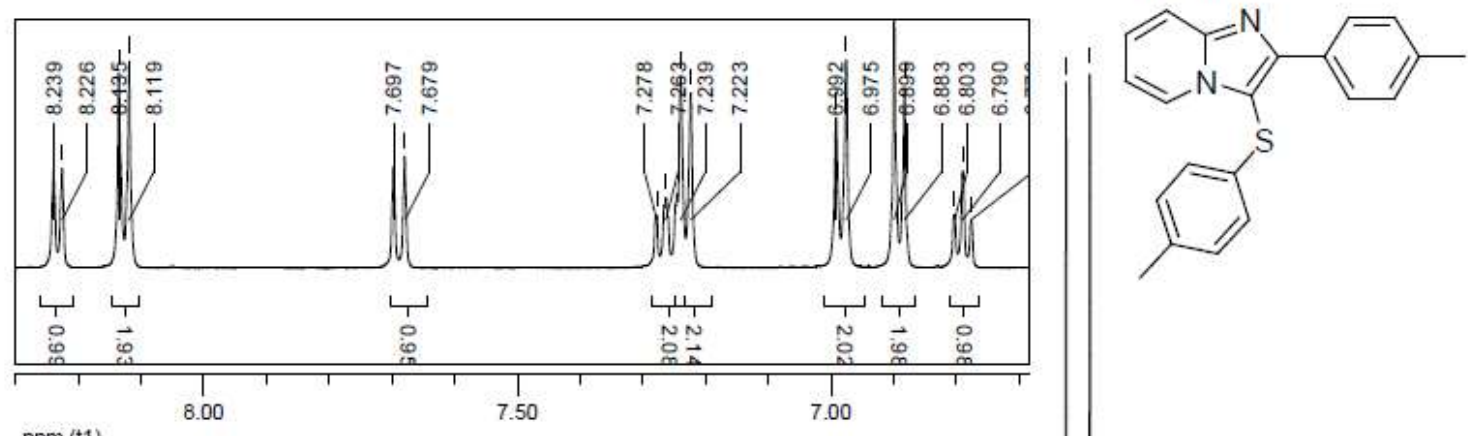

ppm (t1)
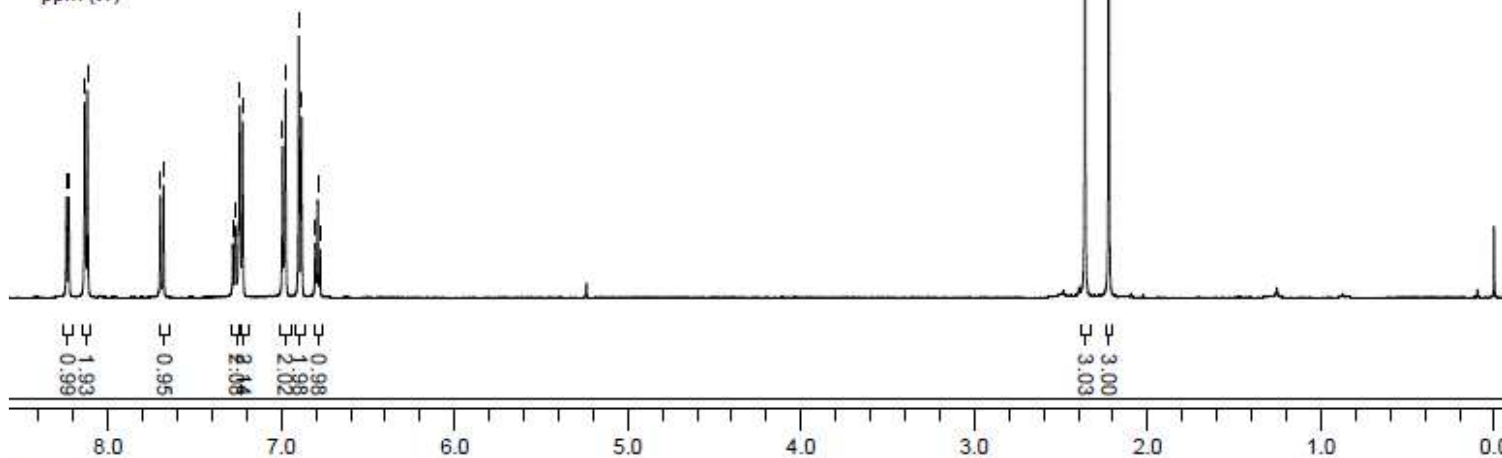

$\mathrm{opm}(\mathrm{t} 1)$

${ }^{1} \mathrm{H}$ NMR of $4 \mathbf{l}$

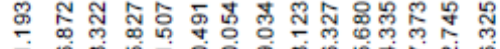

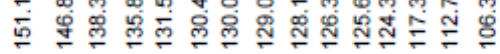

$1[(|l| j \mid j))$
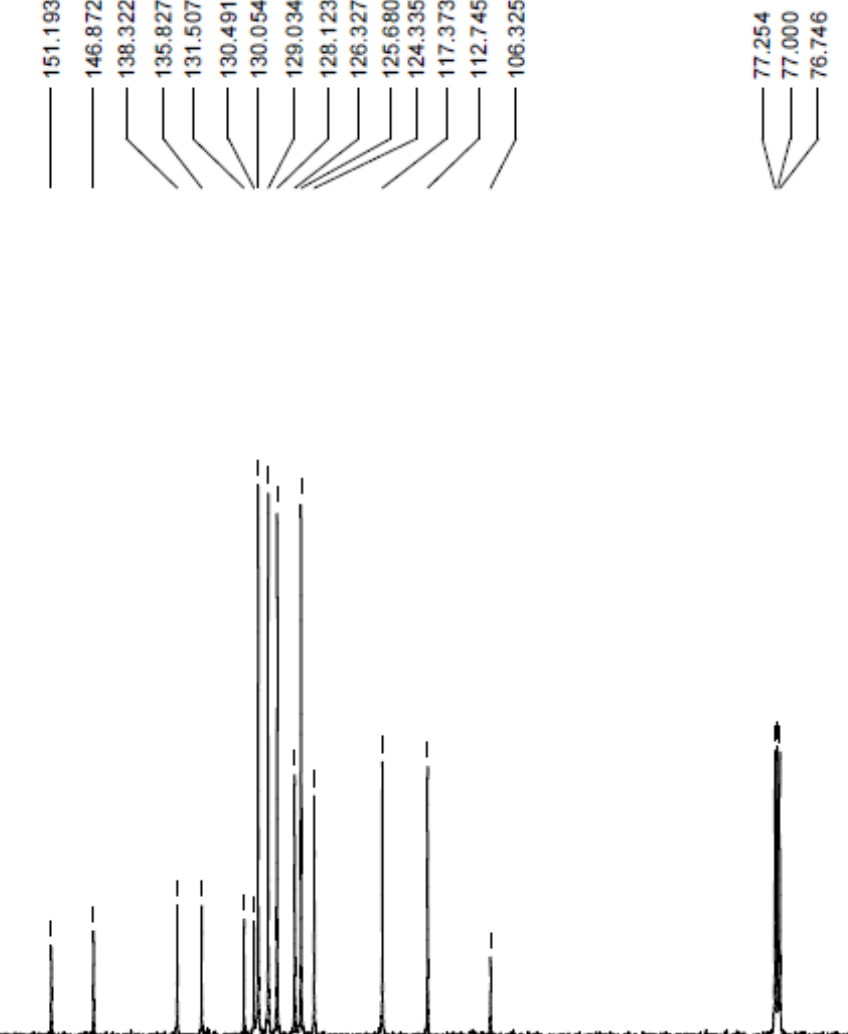

CR-3C

13. NMR in $C:$. .13

$500 \mathrm{MHz}$

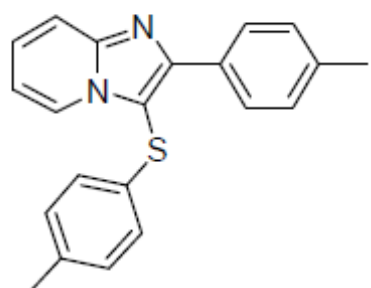

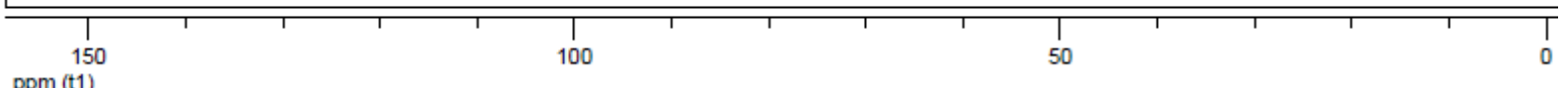


${ }^{13} \mathrm{C}$ NMR of 41

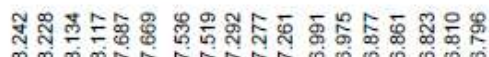

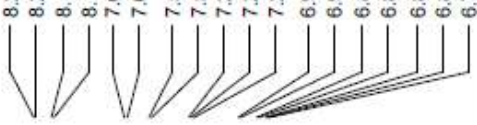

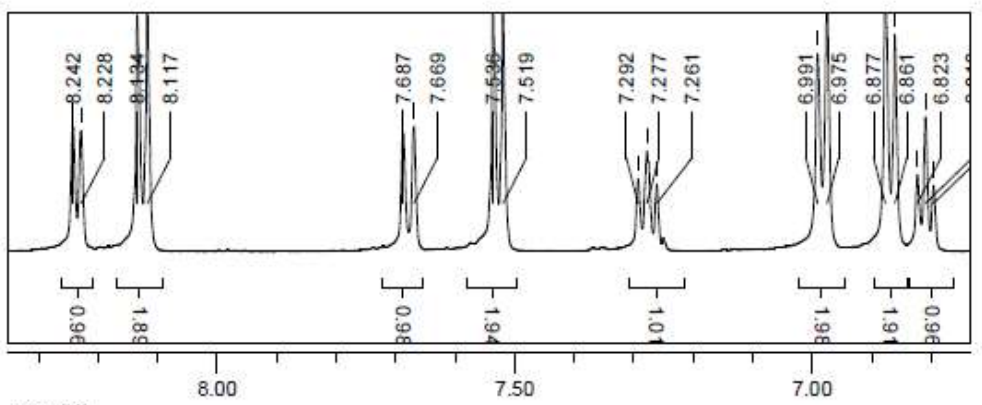

1H NMR in C.NCI3

$500 \mathrm{MHz}$
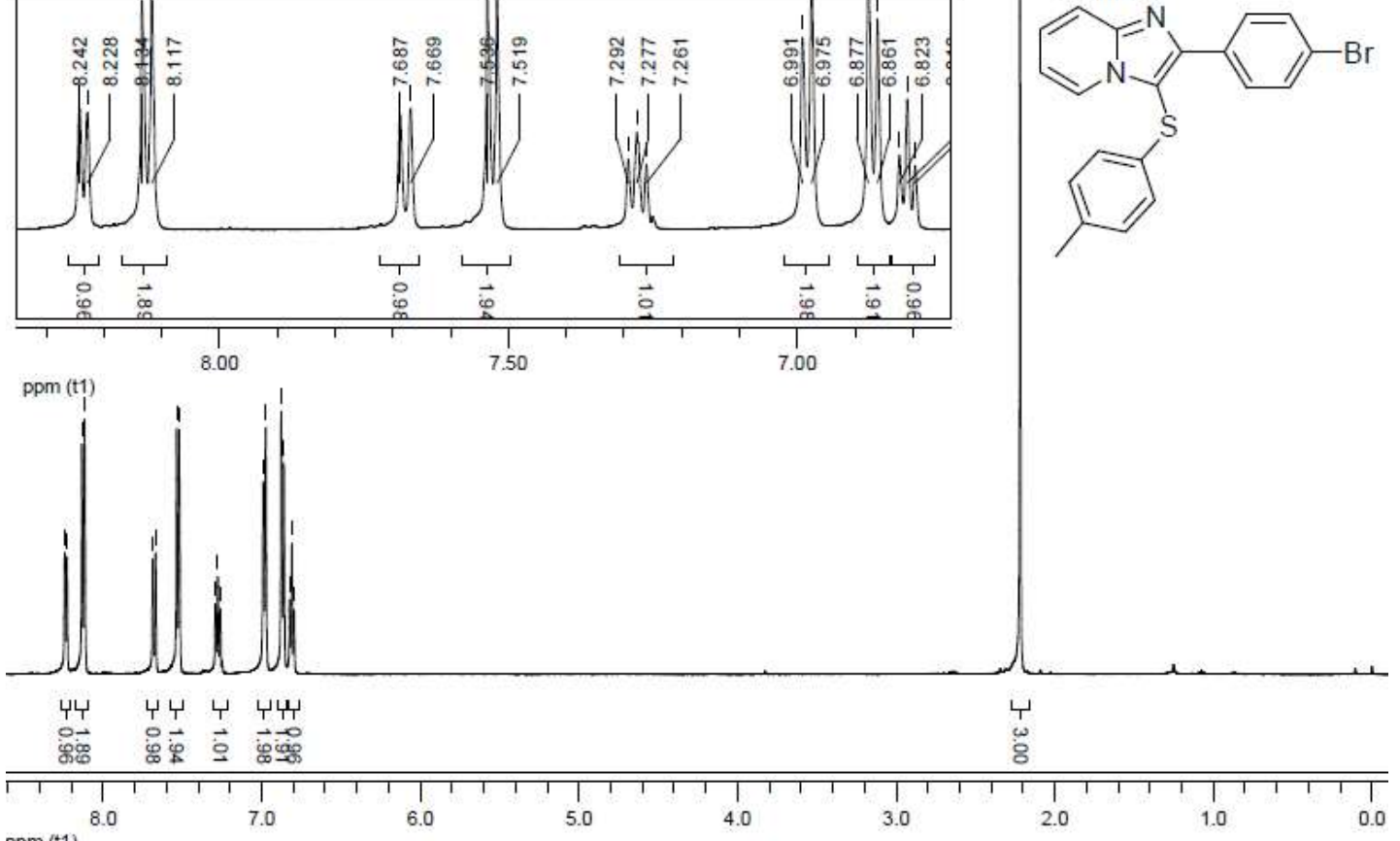

ppm (t1)

H NMR of $\mathbf{4 m}$
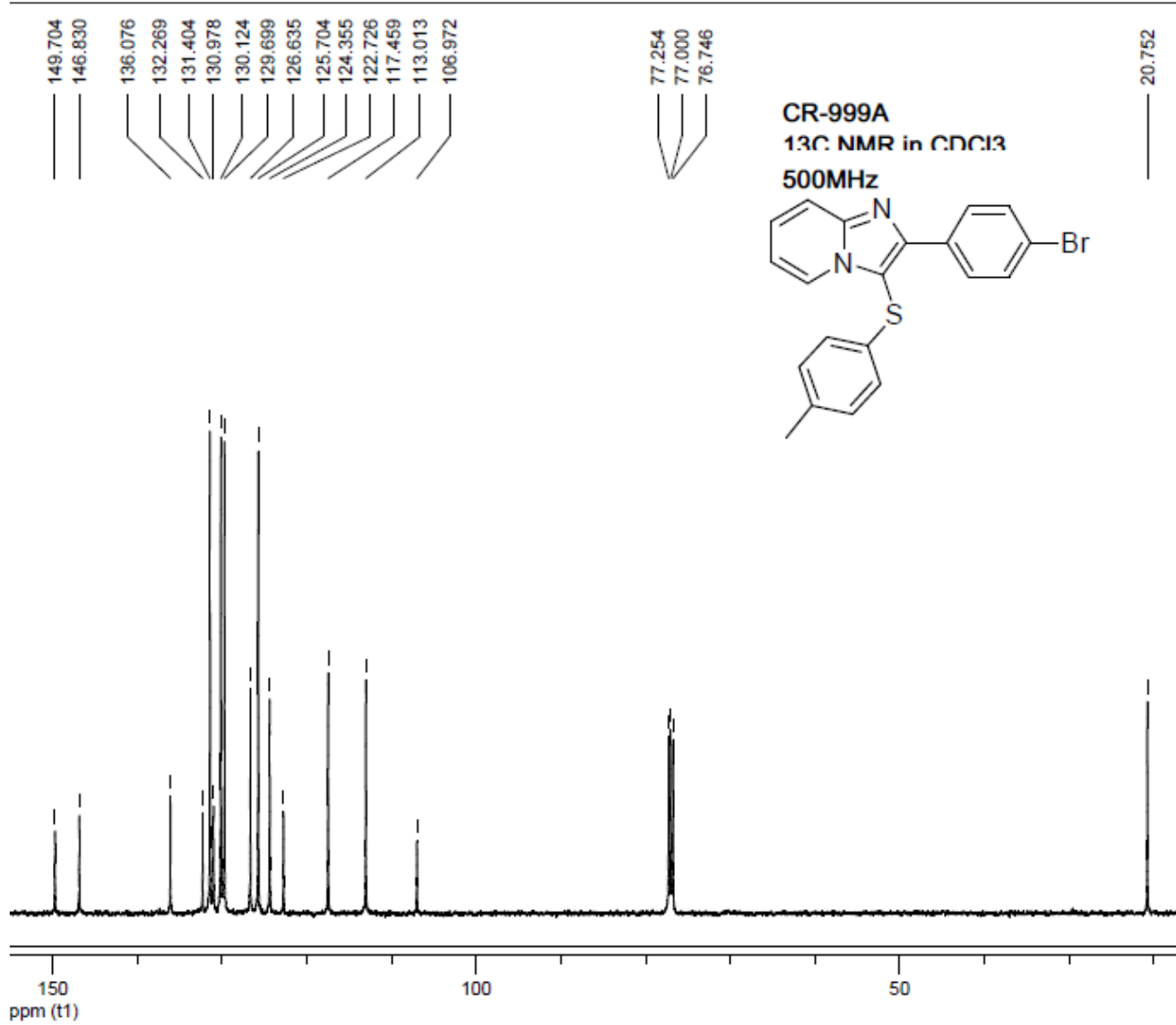

ppm (t1)

${ }^{13} \mathrm{C}$ NMR of $4 \mathrm{~m}$ 


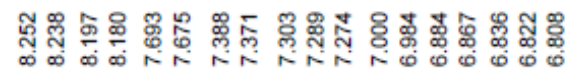

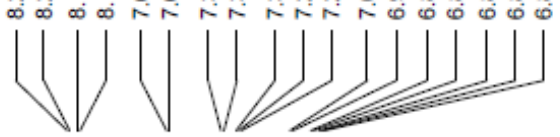

ลูก

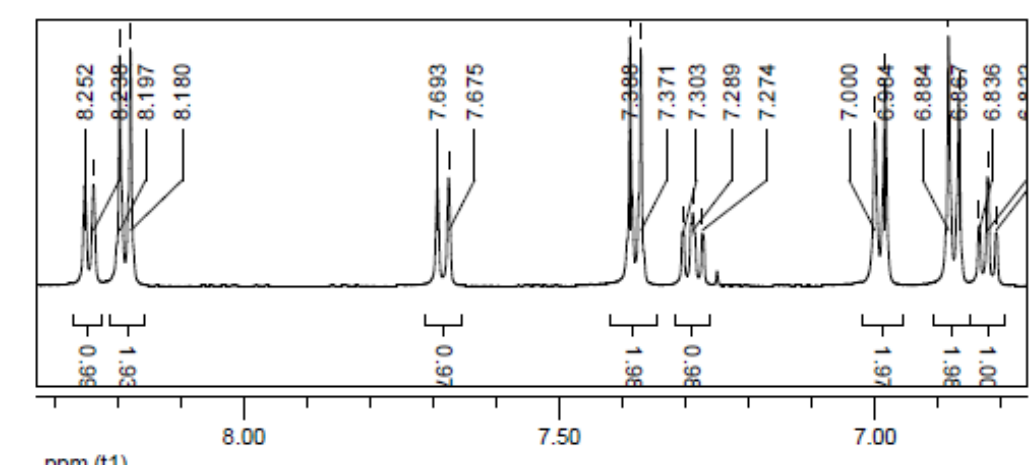

CR-999E

1 H NMR in CICIR

$500 \mathrm{MHz}$

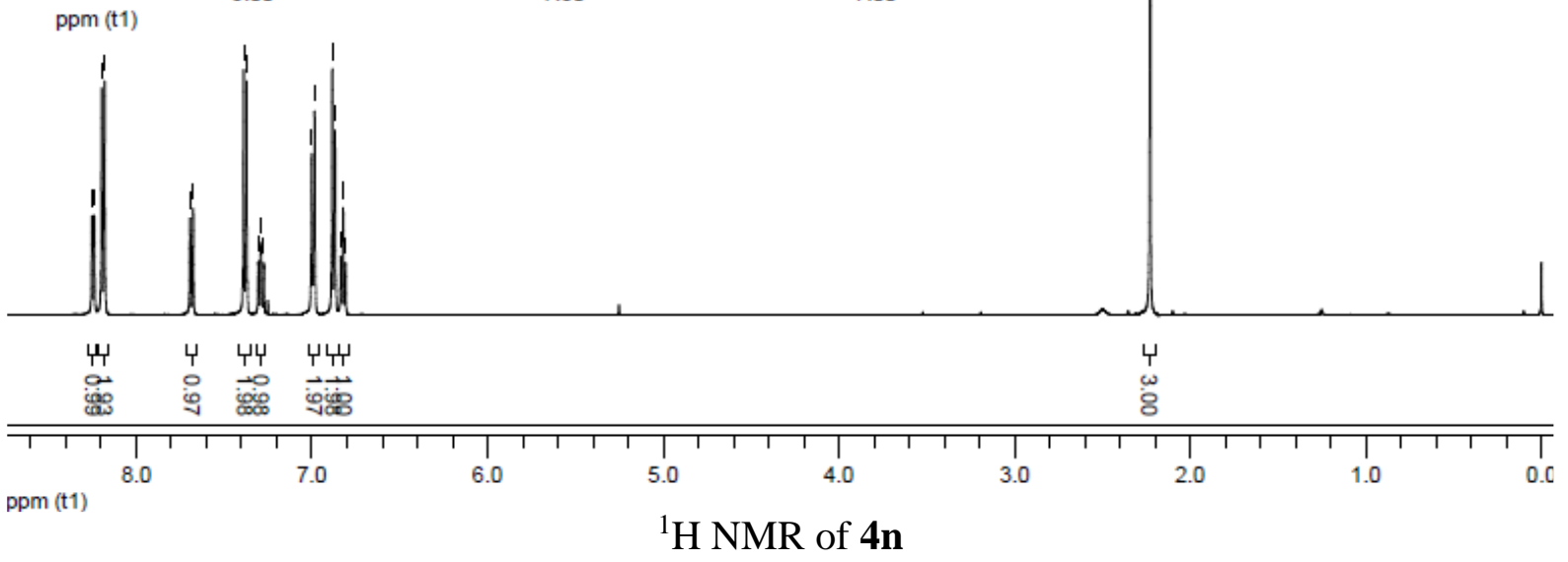

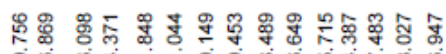

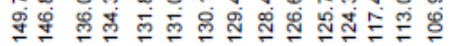

$1[(1) j J j\rfloor j)$

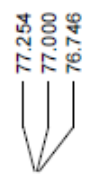

CR-999E

12C. NMAR in COC.12

$500 \mathrm{MHz}$
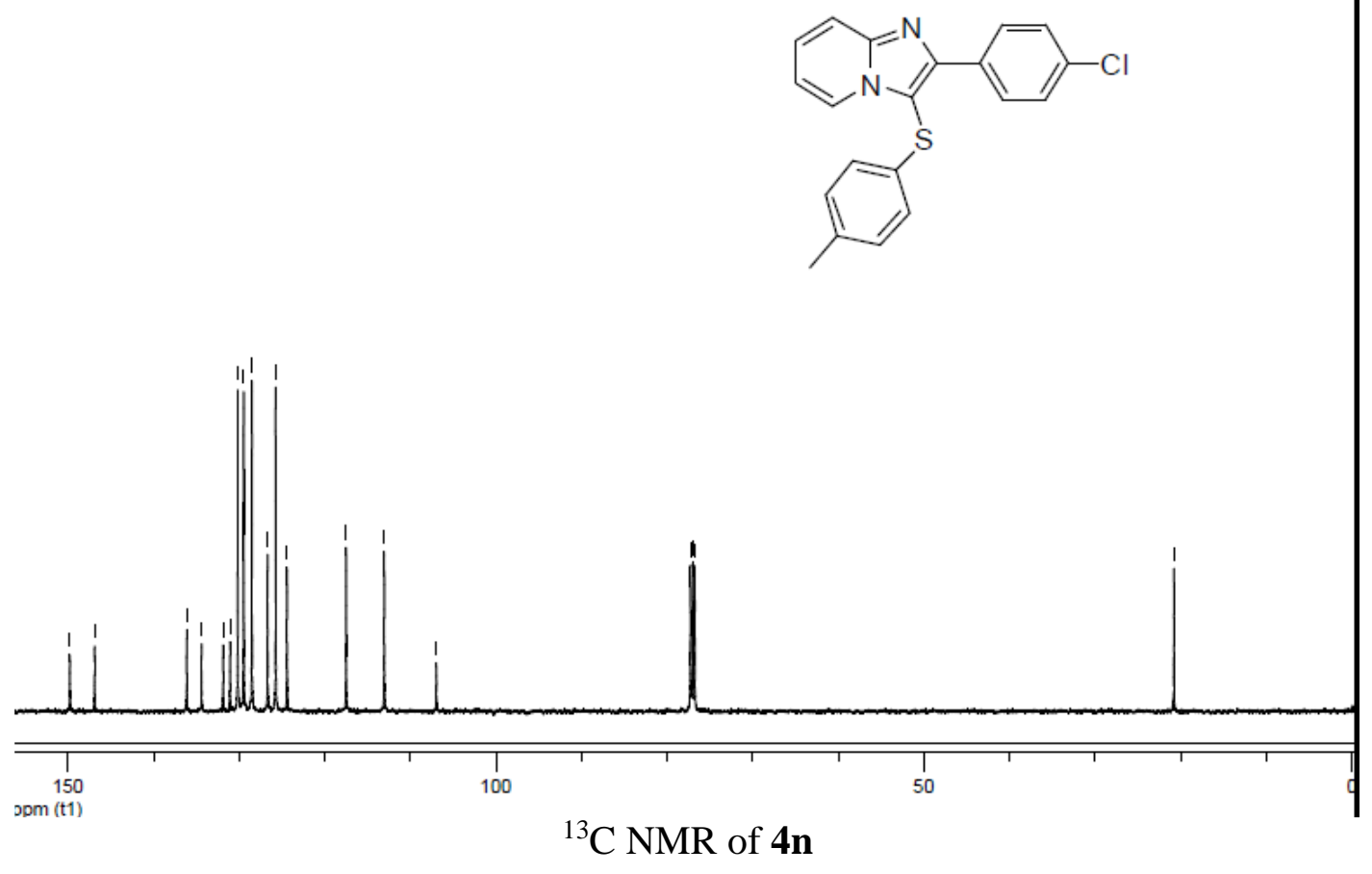


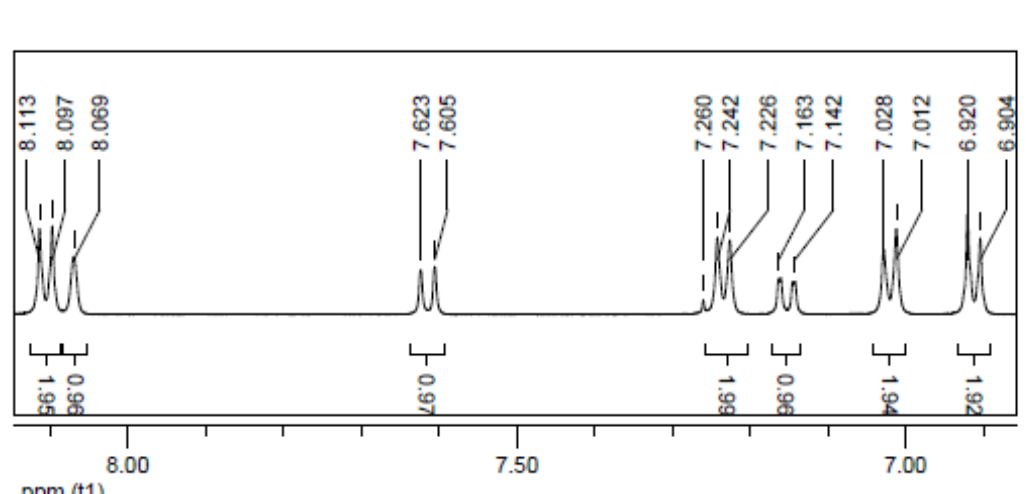

CR-10B

1H NMAR in CחC.I?

$500 \mathrm{MHz}$

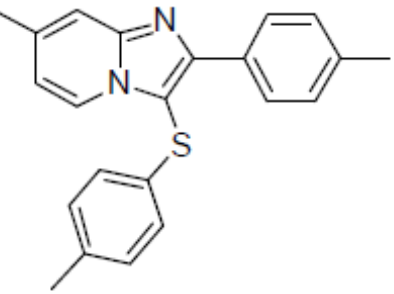

ppm (t1)

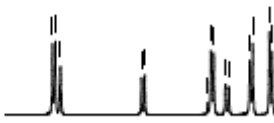

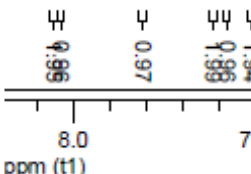

ppm (t1)

${ }^{1} \mathrm{H}$ NMR of $4 \mathbf{o}$

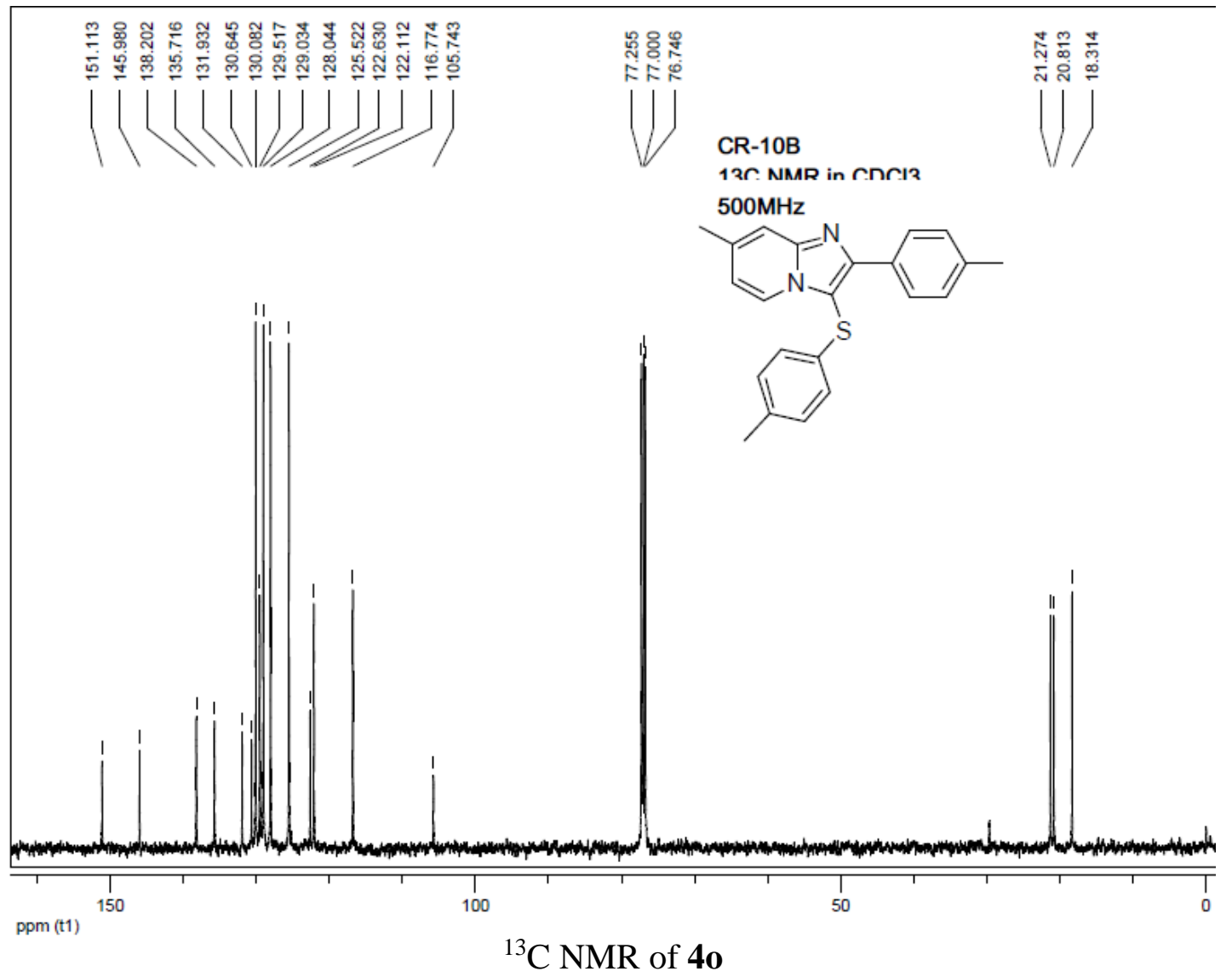



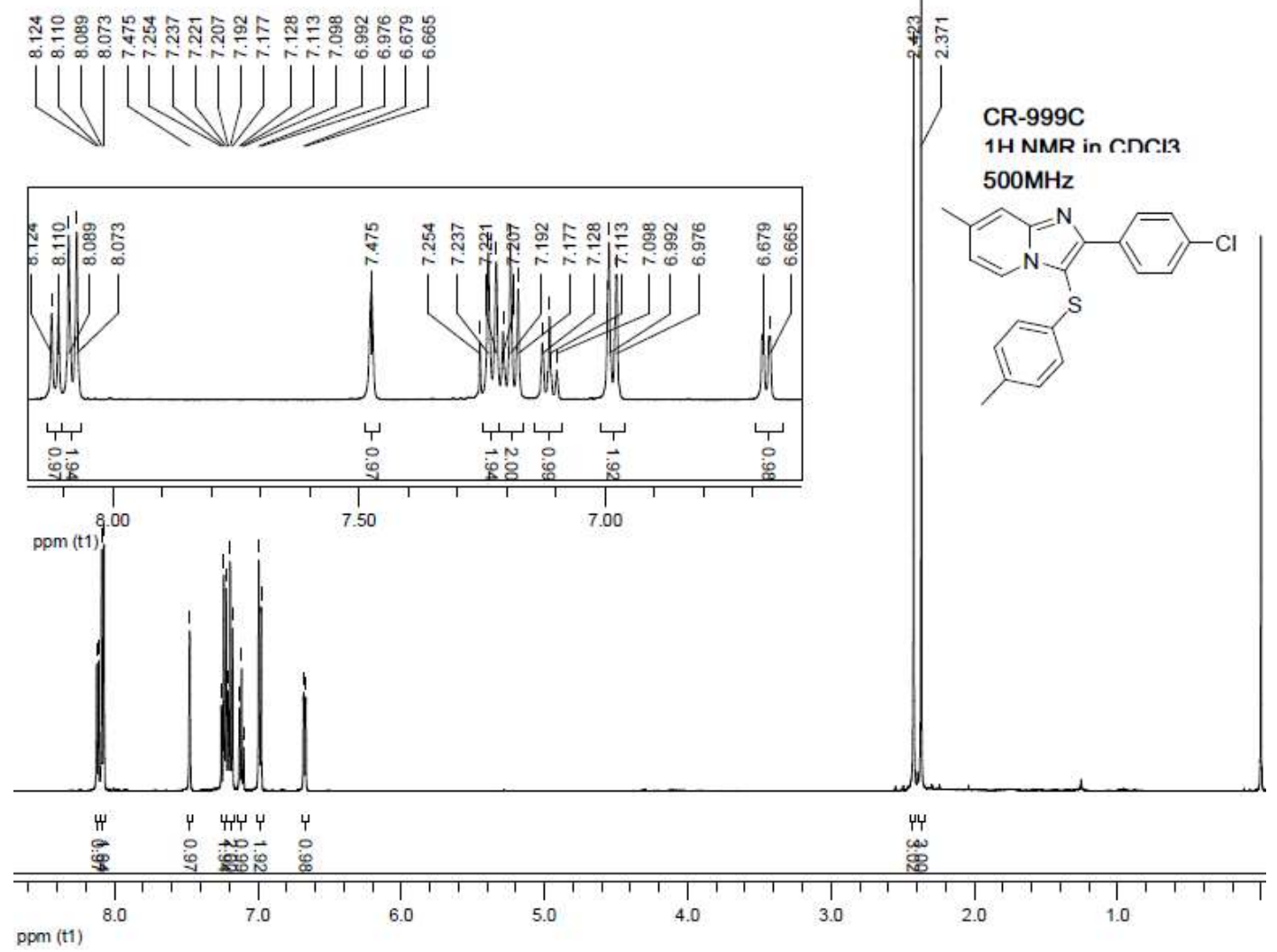

${ }^{1} \mathrm{H}$ NMR of $\mathbf{4 p}$
CR-999C

$500 \mathrm{MHz}$

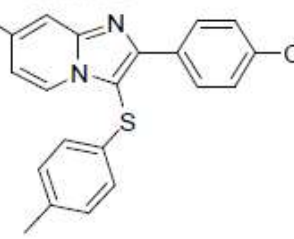

$1 \mathrm{H}$ NMR in C.NCI?

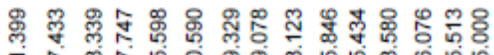

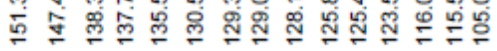

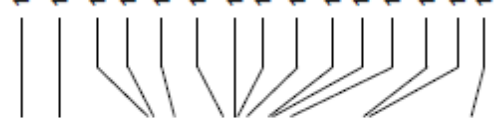
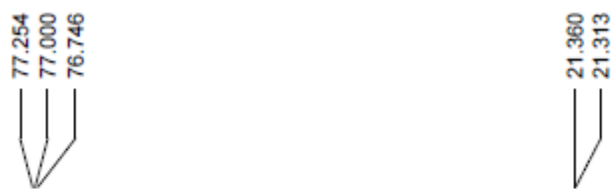

CR-999C

135. NAMR in CחCI?

$500 \mathrm{MHz}$

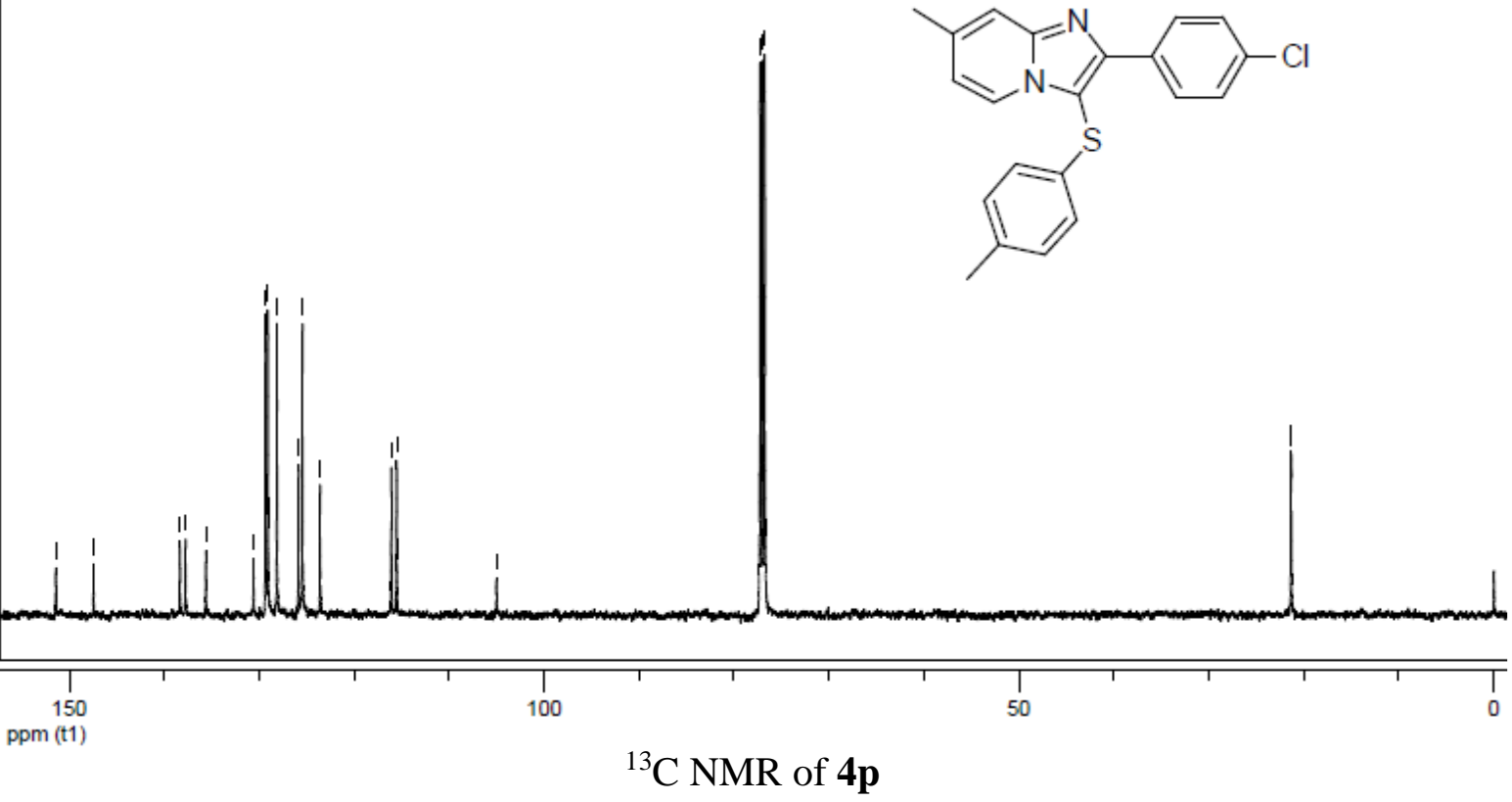




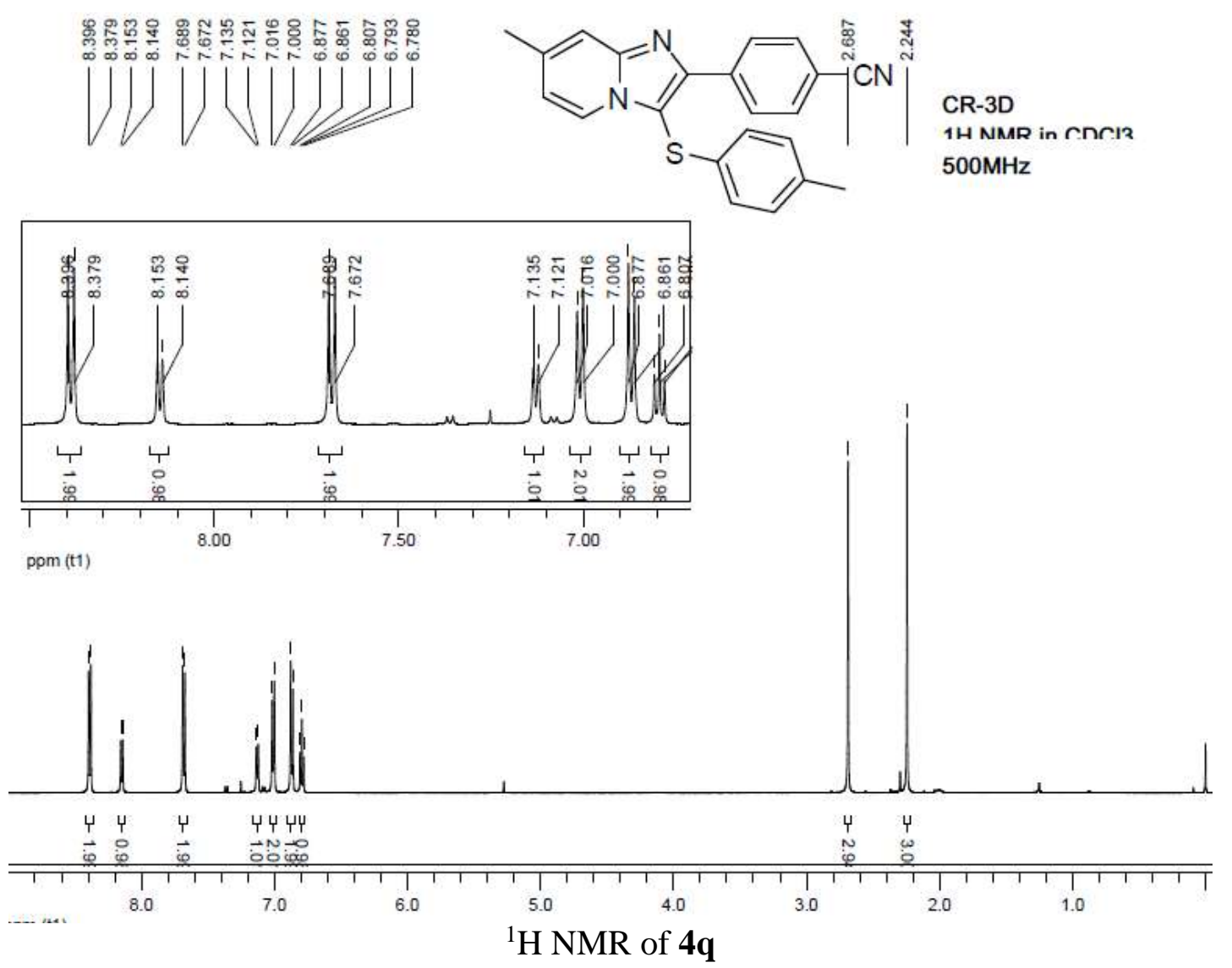

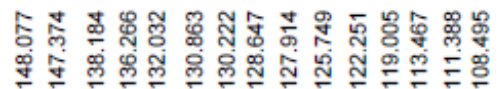

U (|VWUIJ)
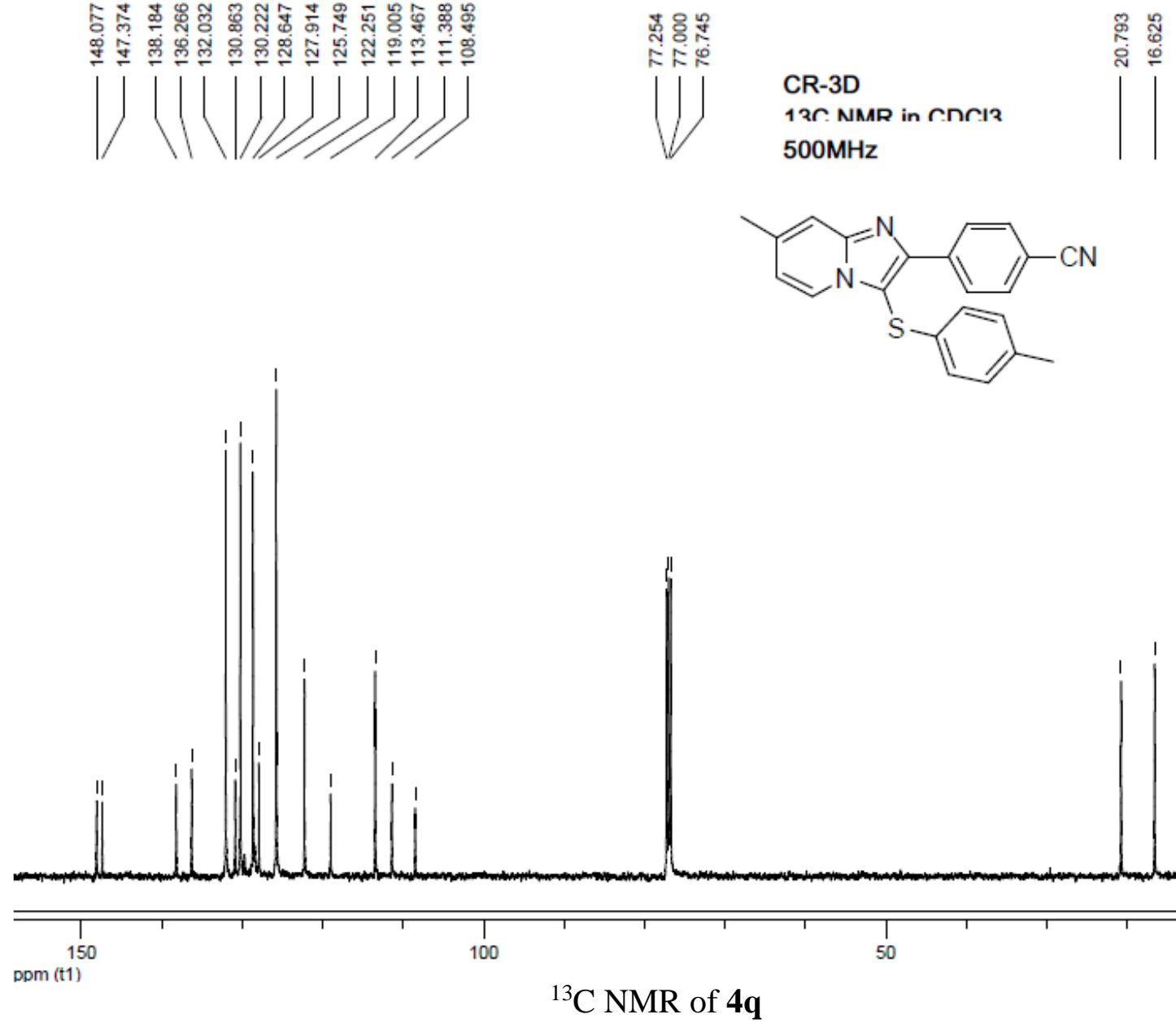

$\left.\right|_{50} ^{1}$ 

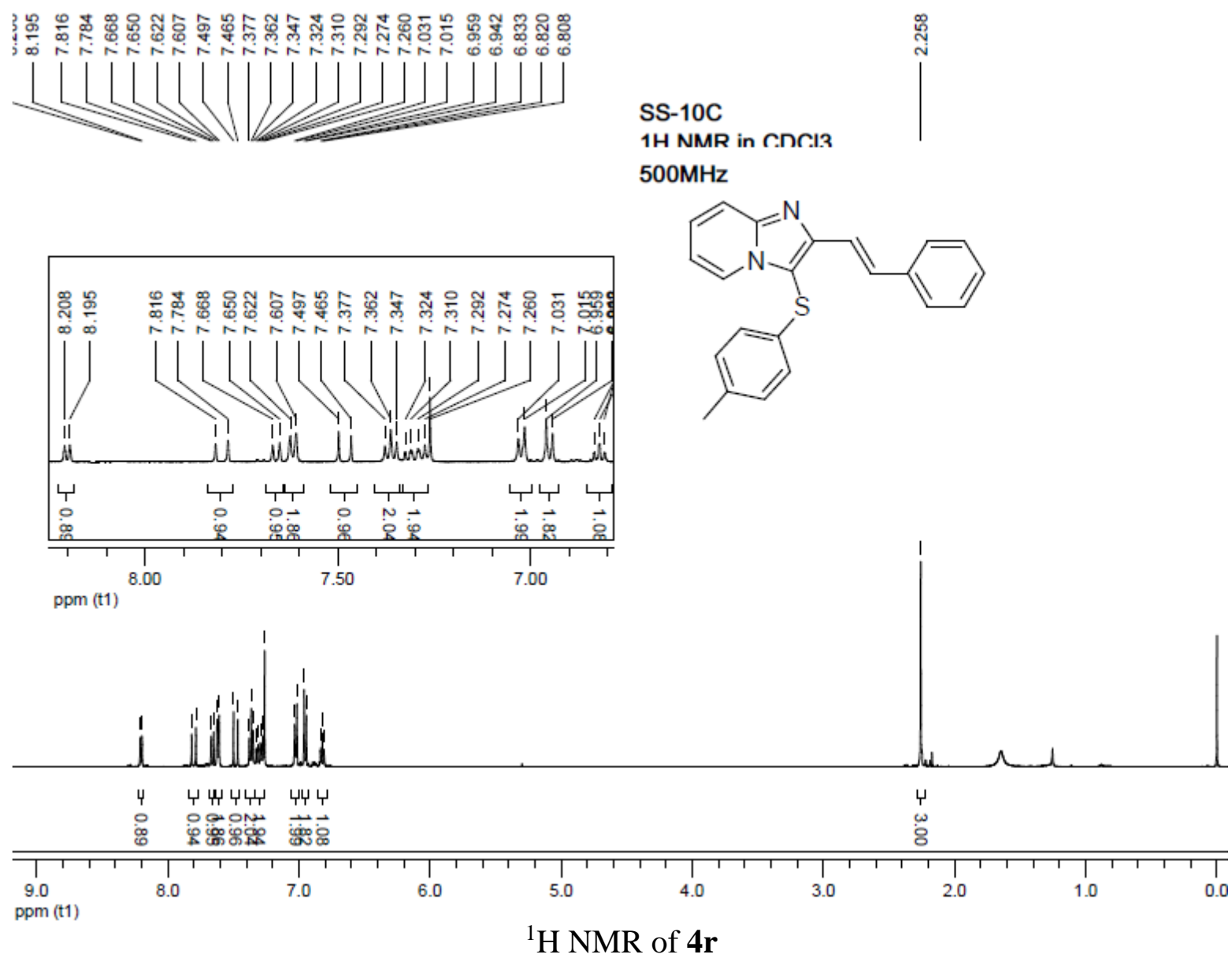

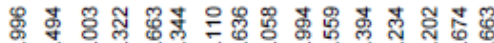

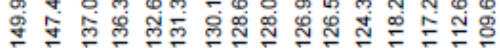

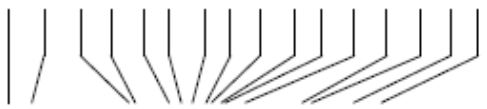

${ }^{1} \mathrm{H}$ NMR of $\mathbf{4 r}$
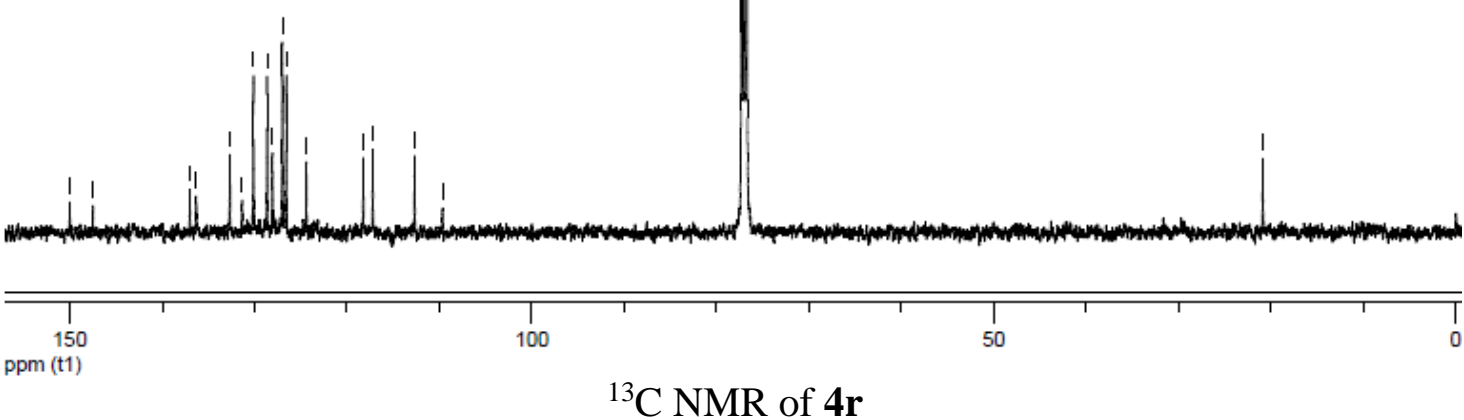


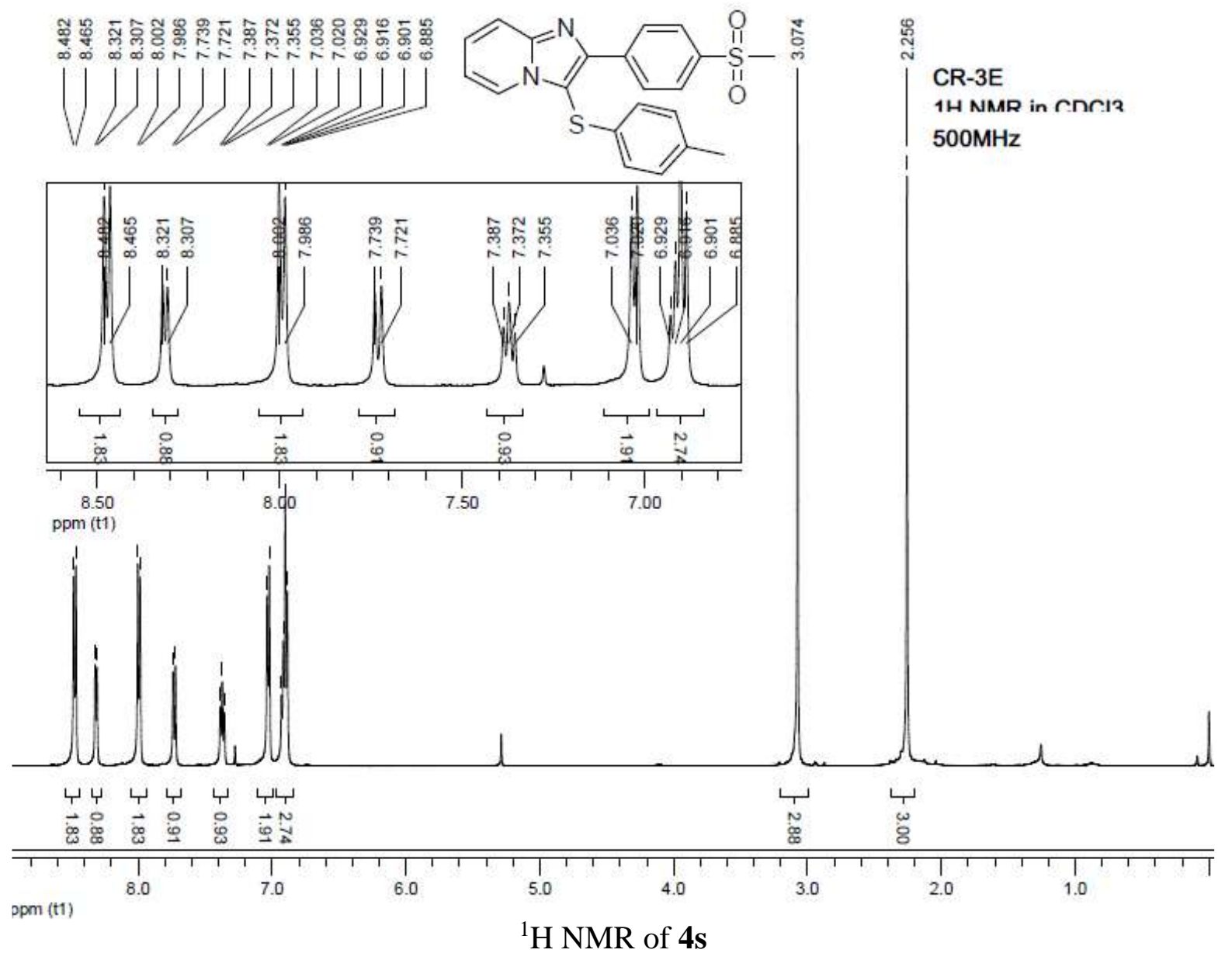

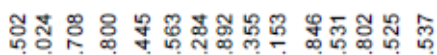

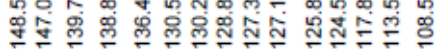

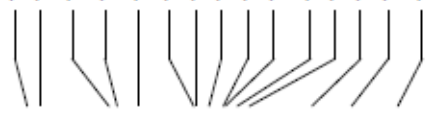
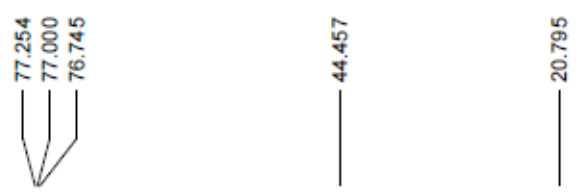

CR-3E

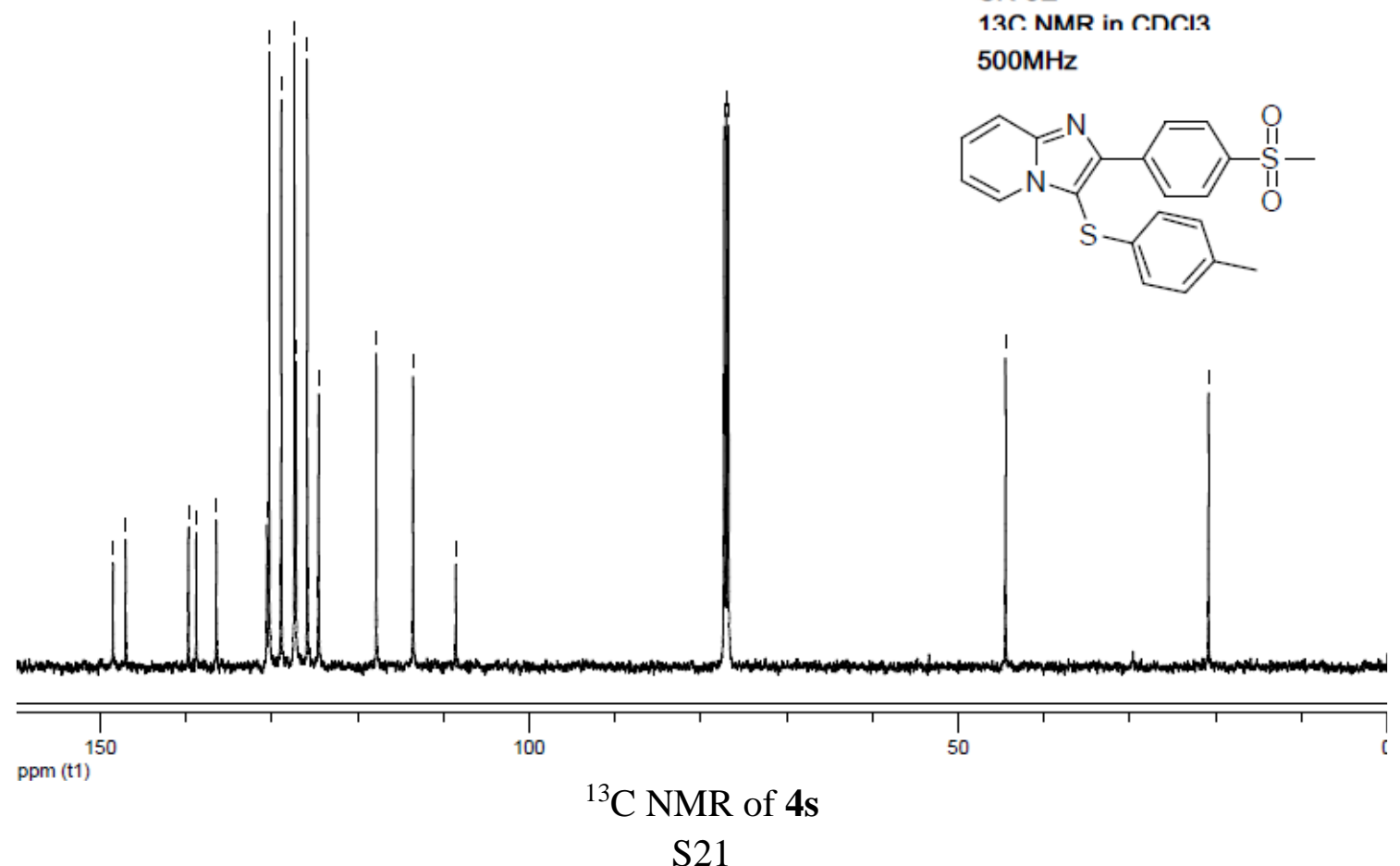




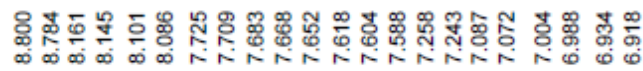

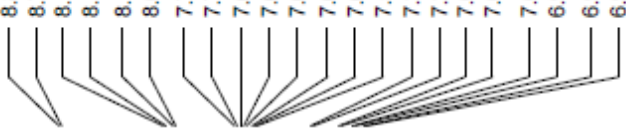
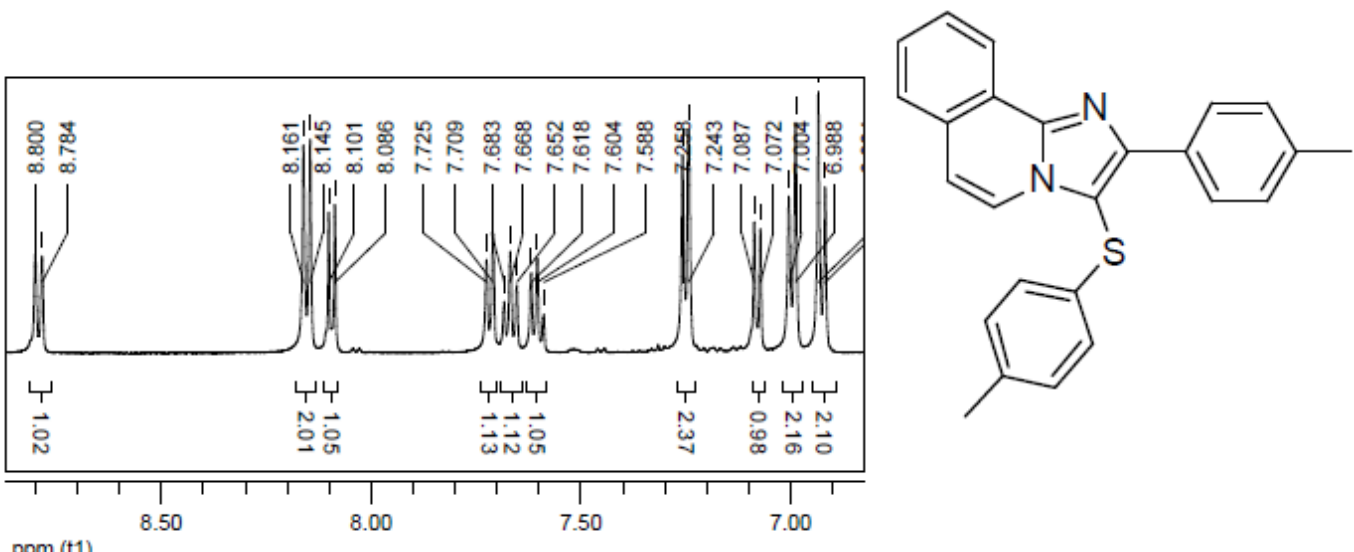

ppm (t1)

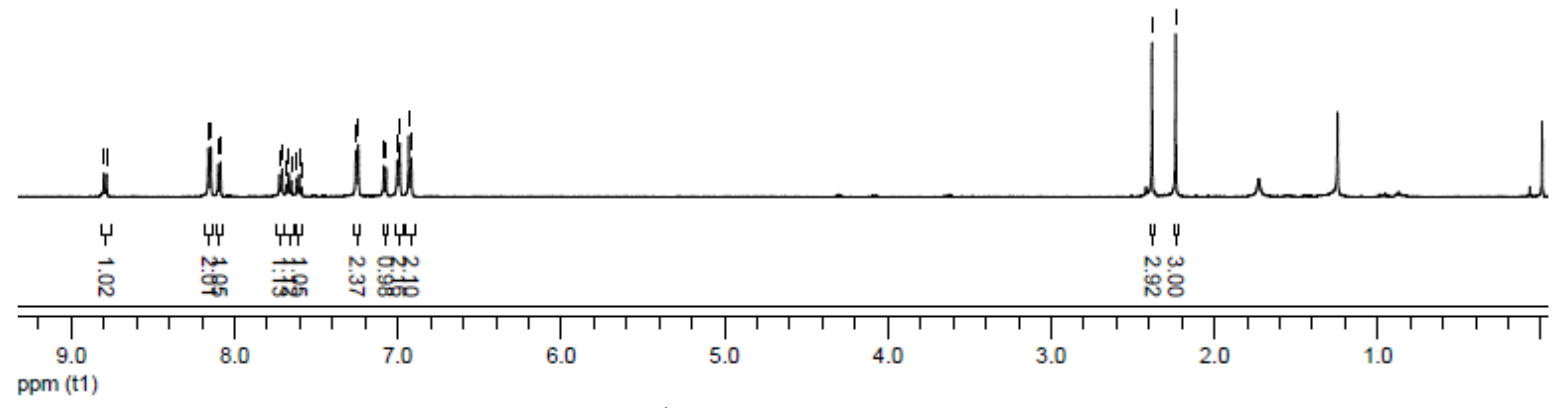

${ }^{1} \mathrm{H}$ NMR of $\mathbf{4 u}$

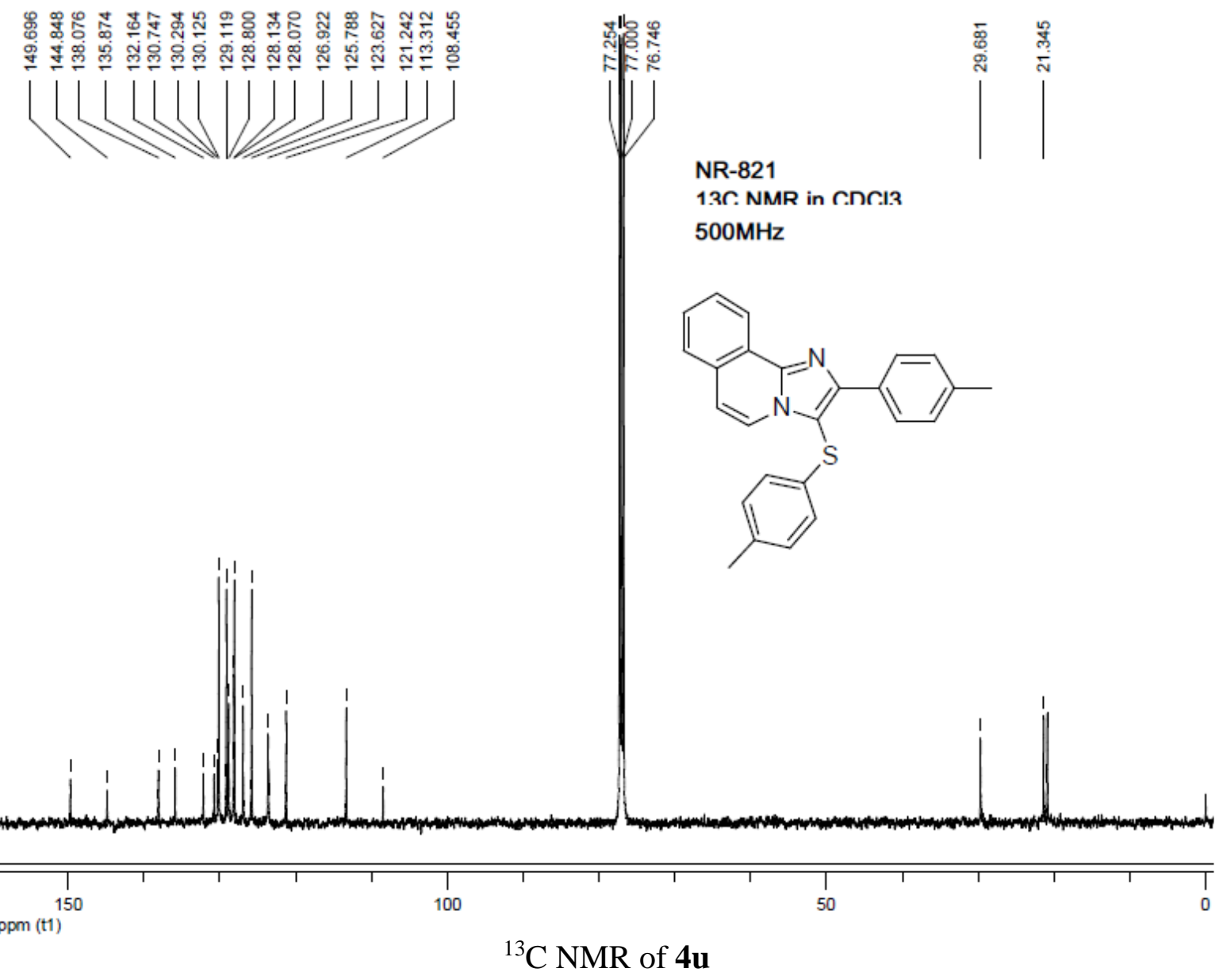



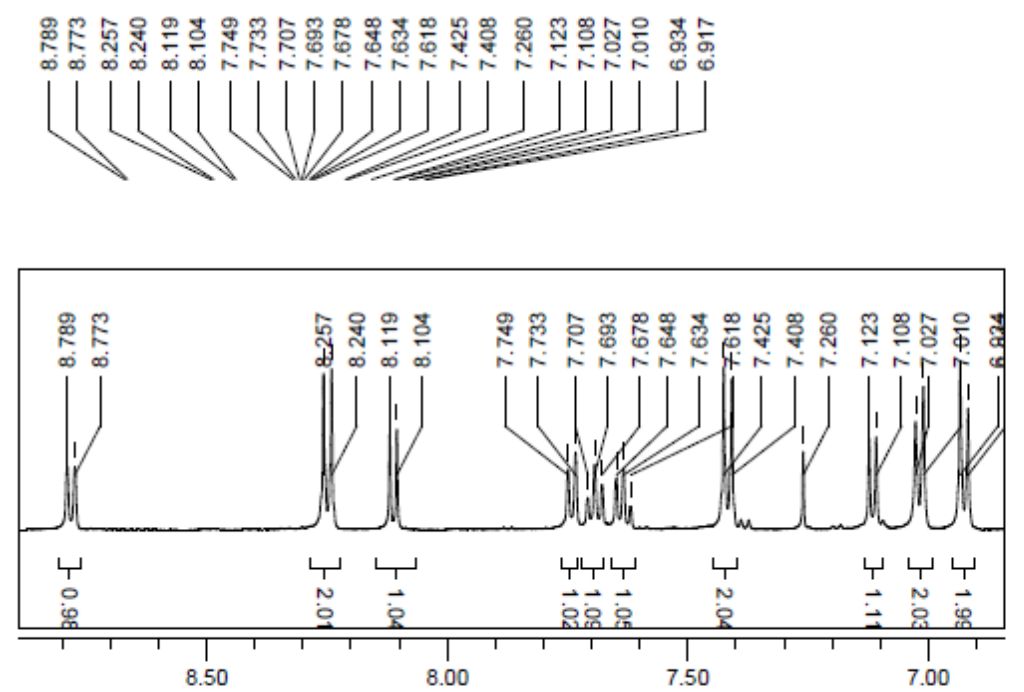

ppm (t1)
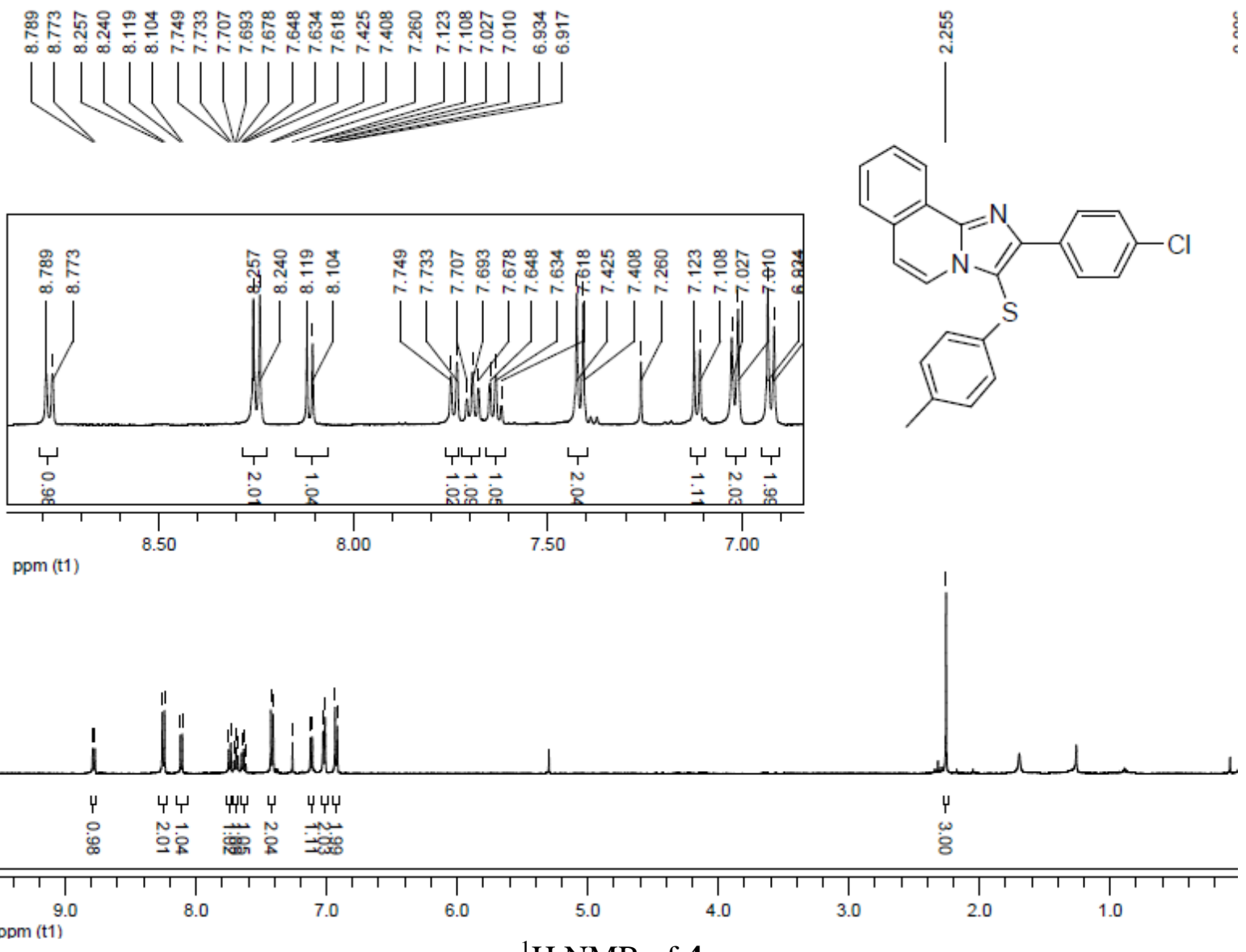

${ }^{1} \mathrm{H}$ NMR of $\mathbf{4 v}$

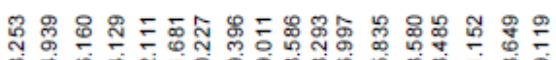

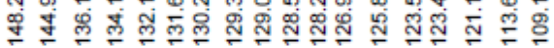
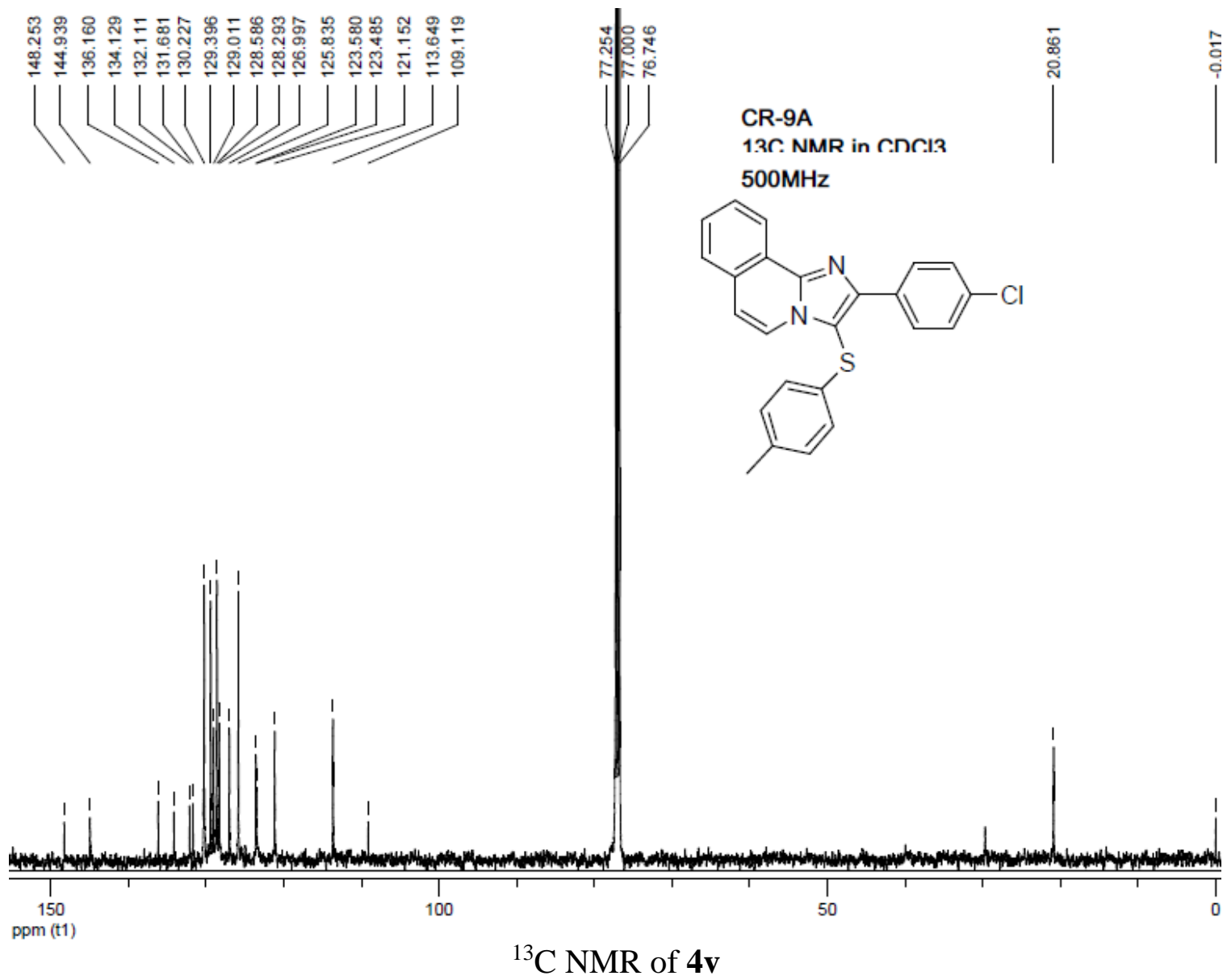

CR-9A

1.3C. NMR in C.NC.I3

$500 \mathrm{MHz}$
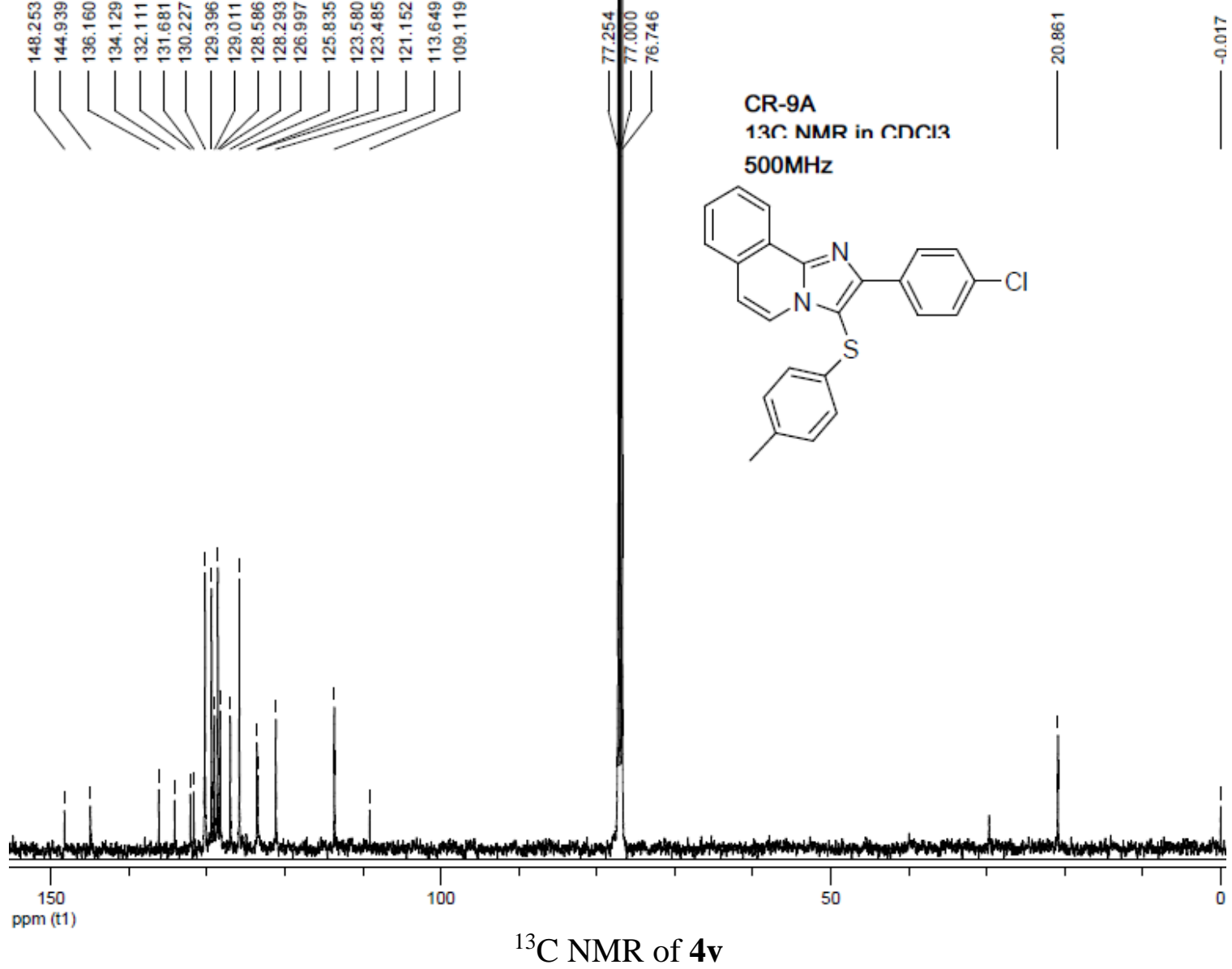

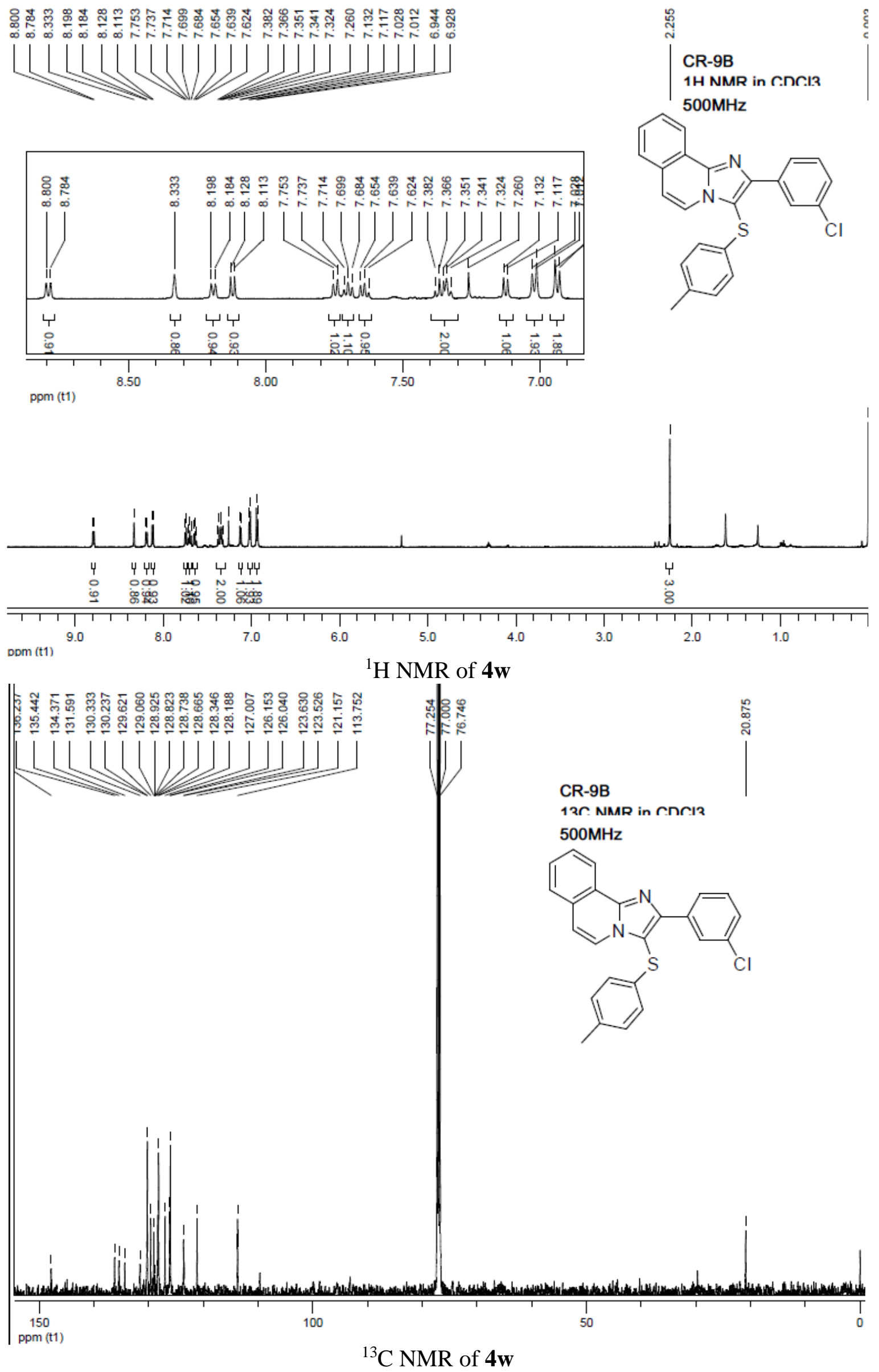


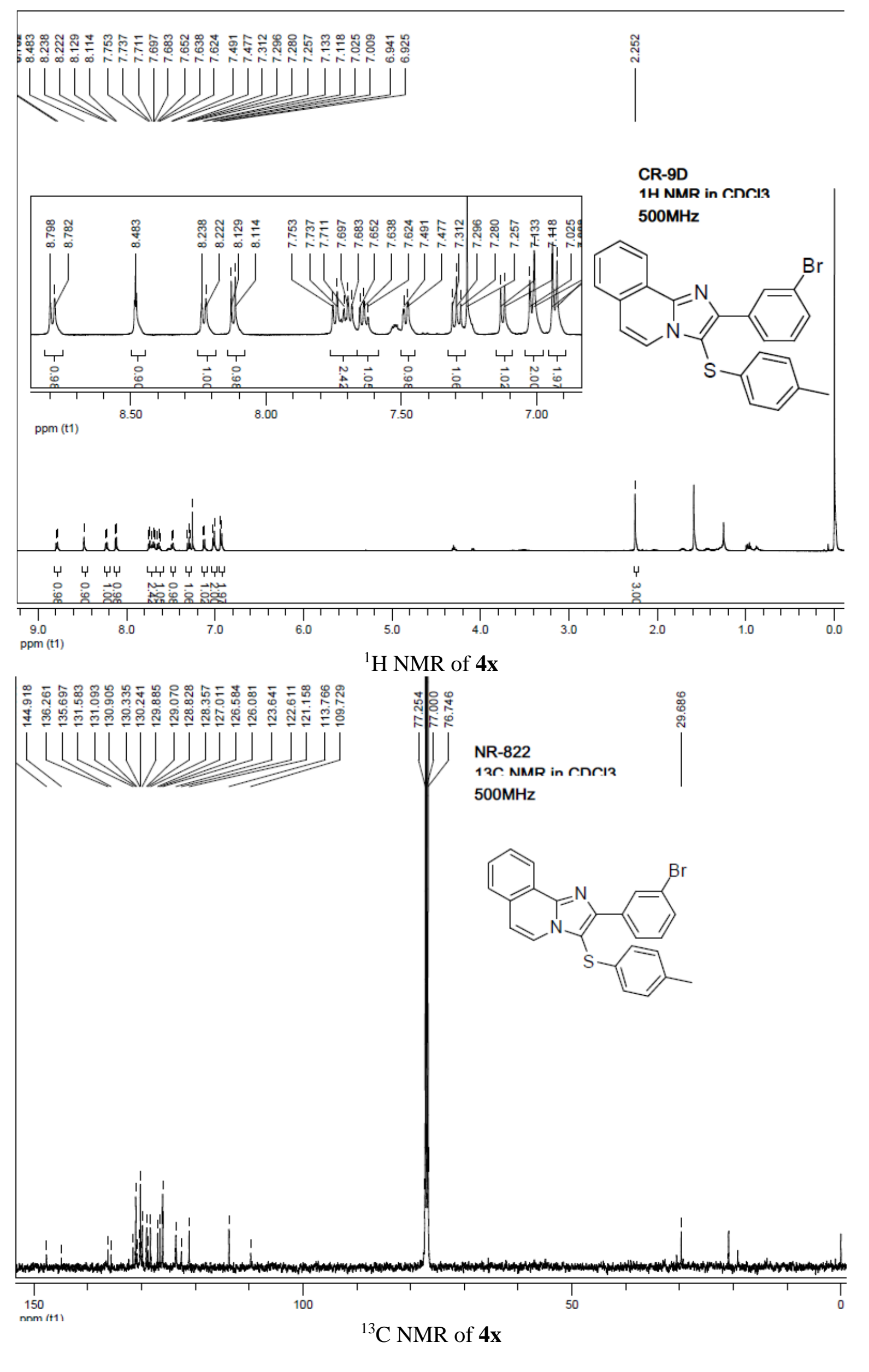


.

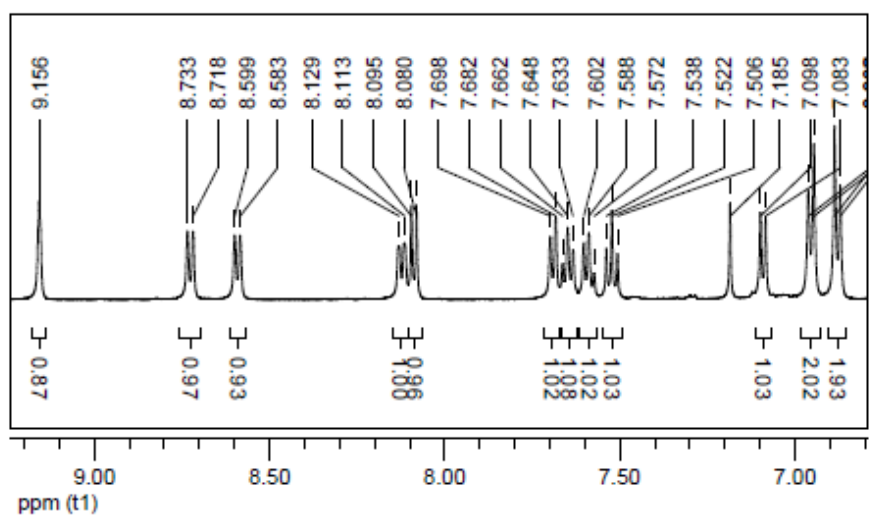

\section{NR-823}

1H NMR in C.NCI? $500 \mathrm{MHz}$

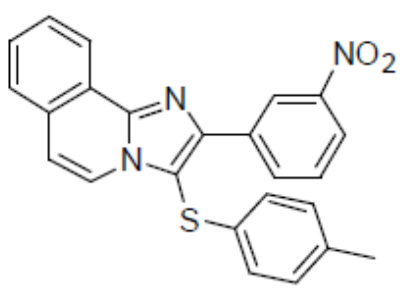

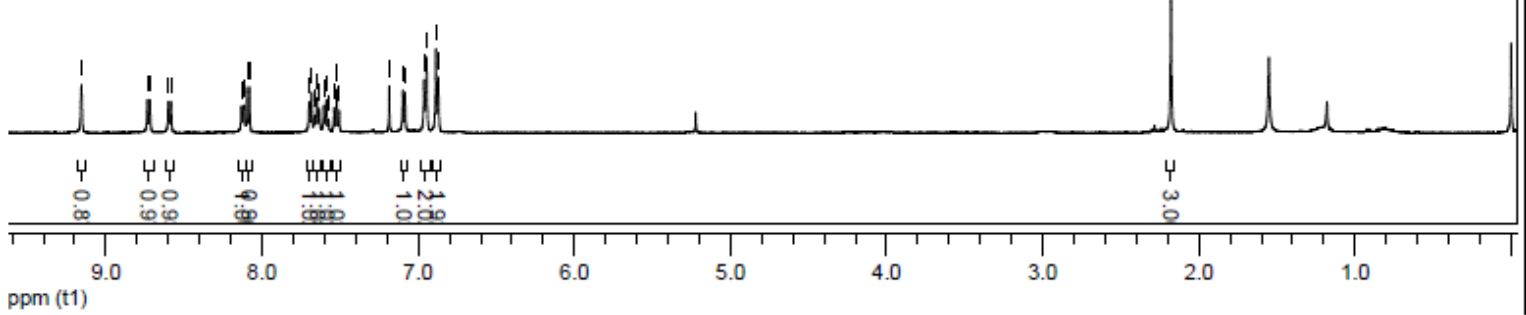

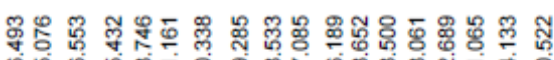

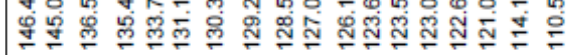

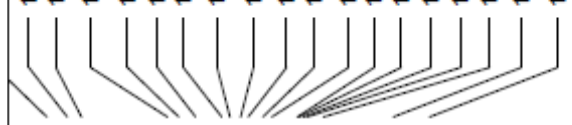
${ }^{1} \mathrm{H}$ NMR of $\mathbf{4 y}$

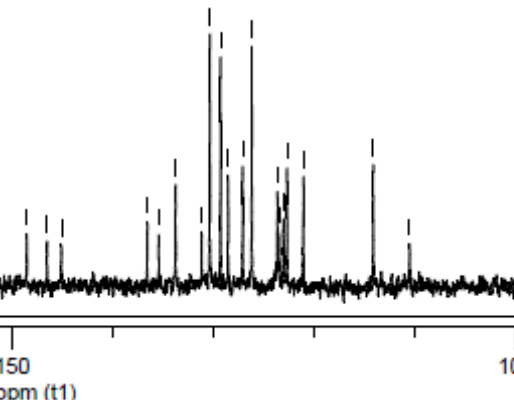<smiles>Cc1ccc(Sc2c(-c3cccc([N+](=O)[O-])c3)nc3c4ccccc4ccn23)cc1</smiles>

${ }^{13} \mathrm{C}$ NMR of $\mathbf{4 y}$ 


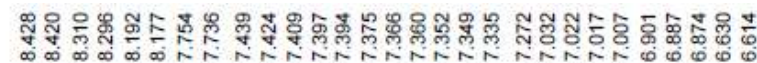
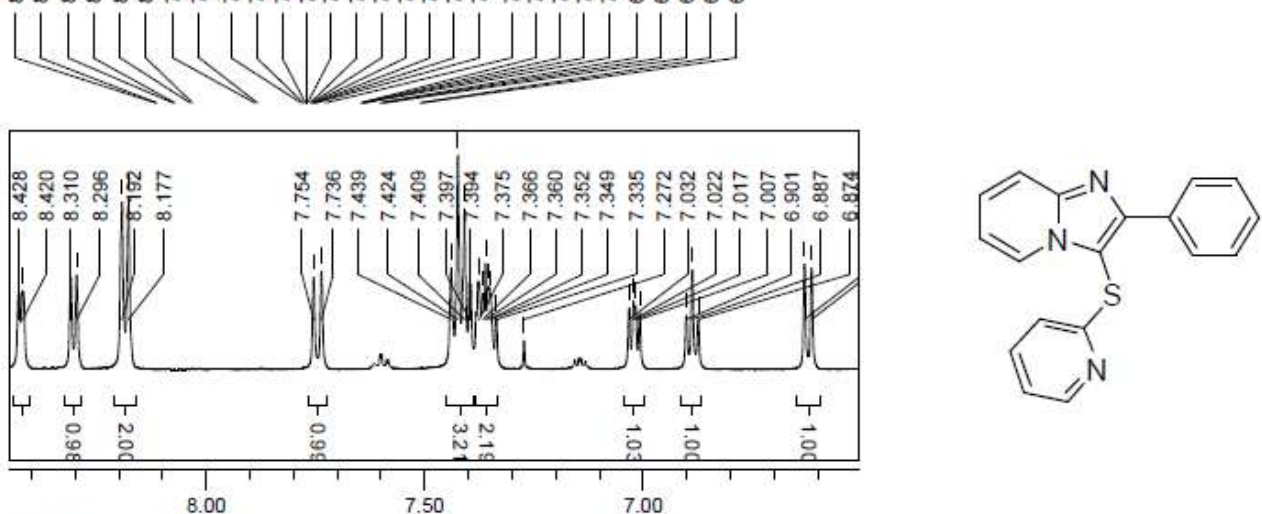

$\mathrm{ppm}(\mathrm{t} 1)$

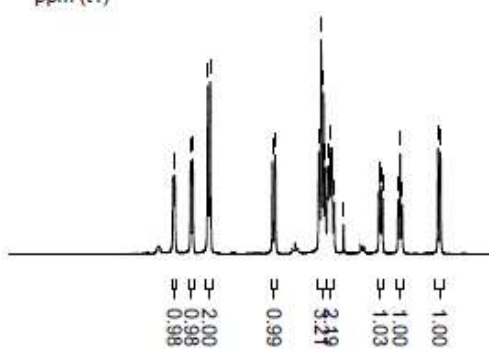

CR-1042D

1H NMR in C.nC.I3

$500 \mathrm{MHz}$

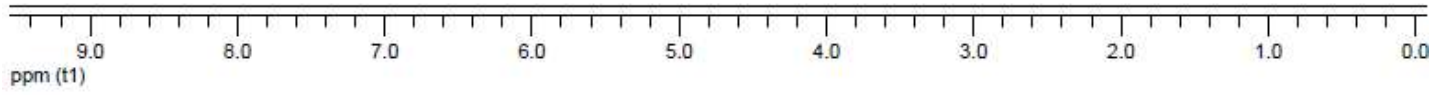

${ }^{1} \mathrm{H}$ NMR of $\mathbf{4 z}$

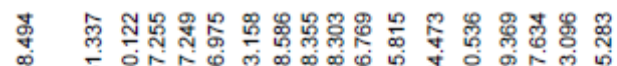

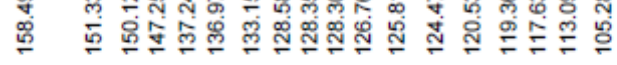

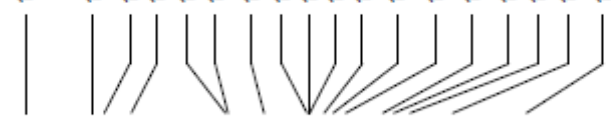

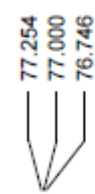

CR-1042D

12C. NMMR in CחCI?

$500 \mathrm{MHz}$
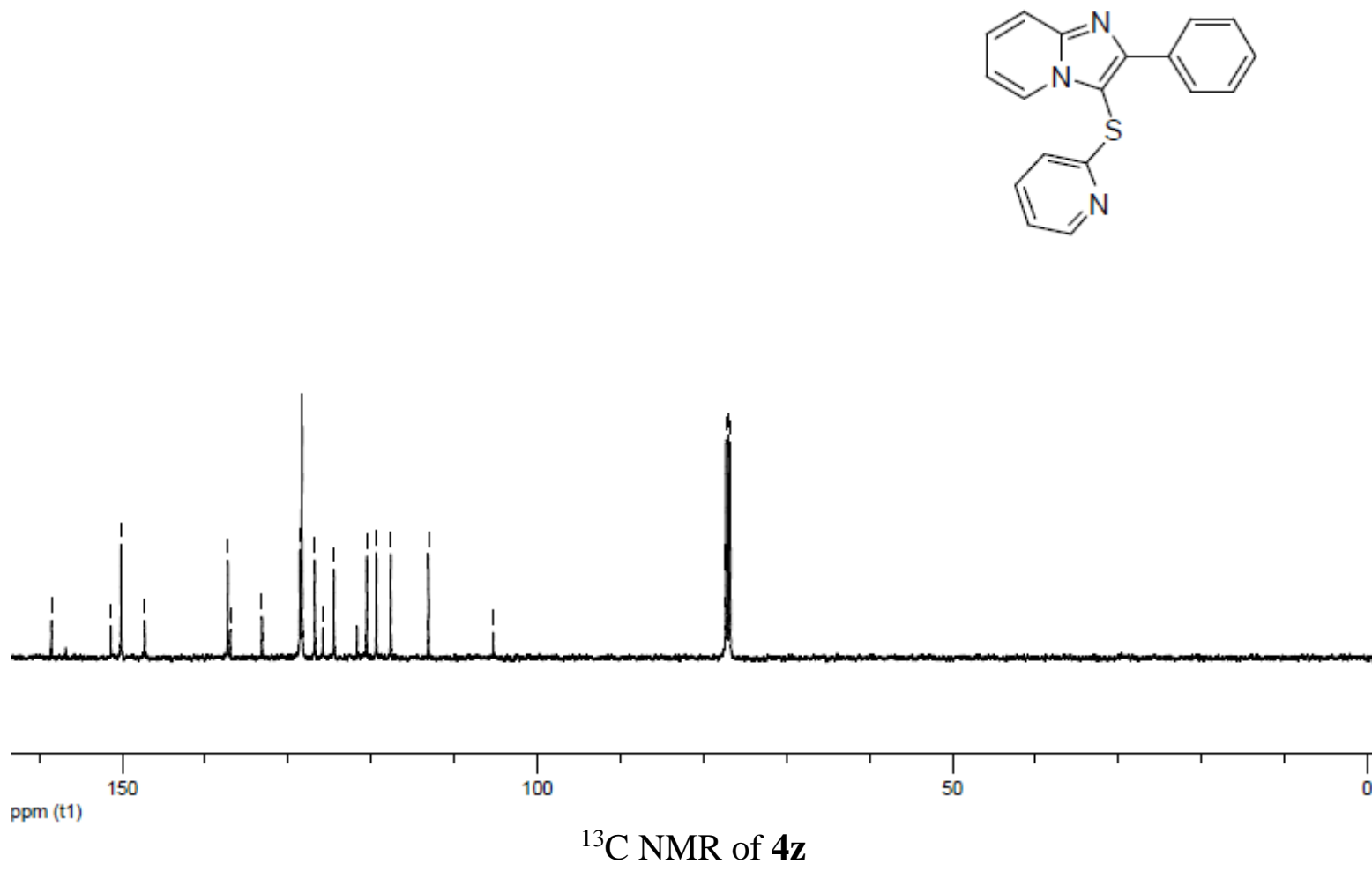

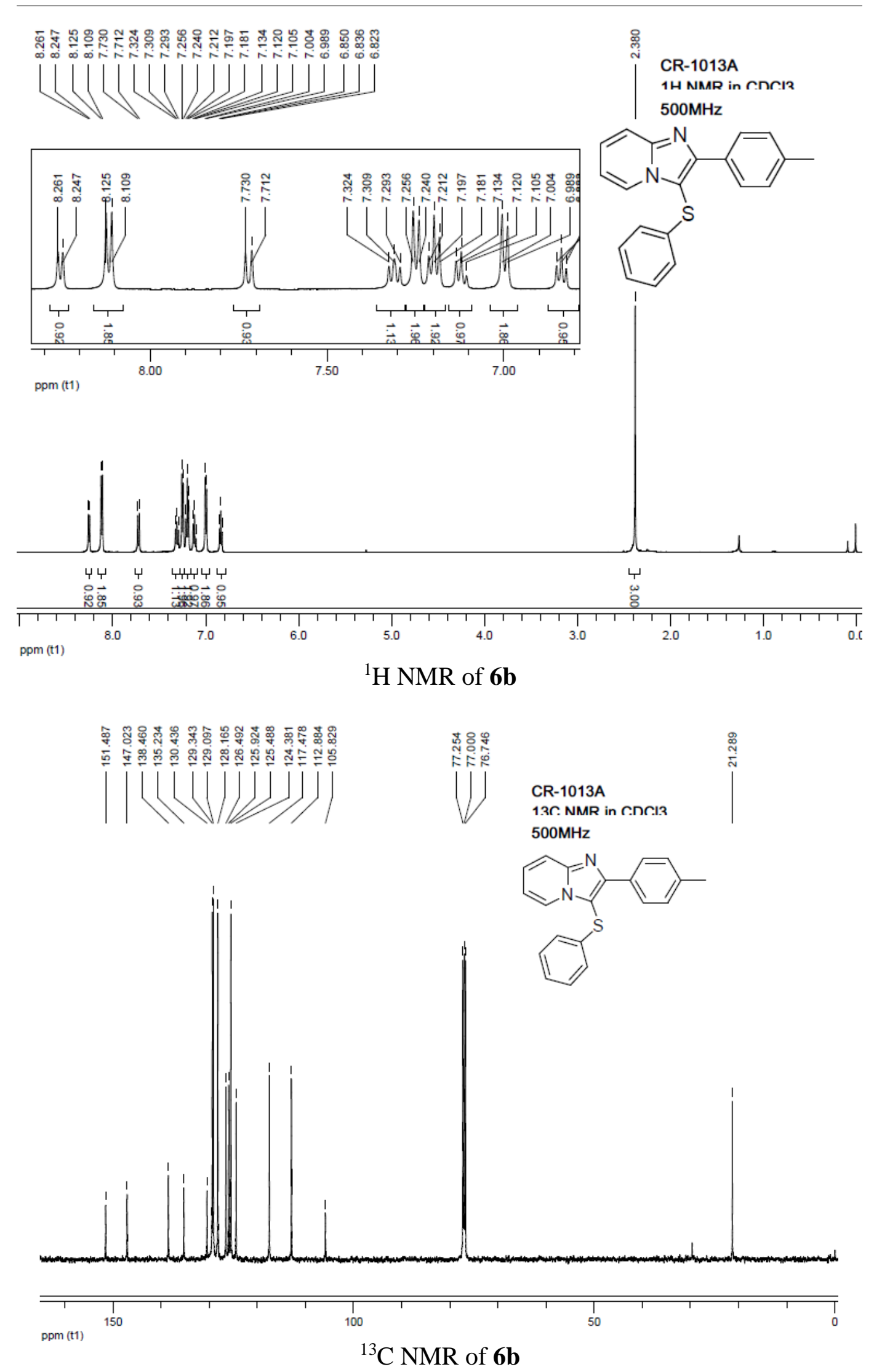

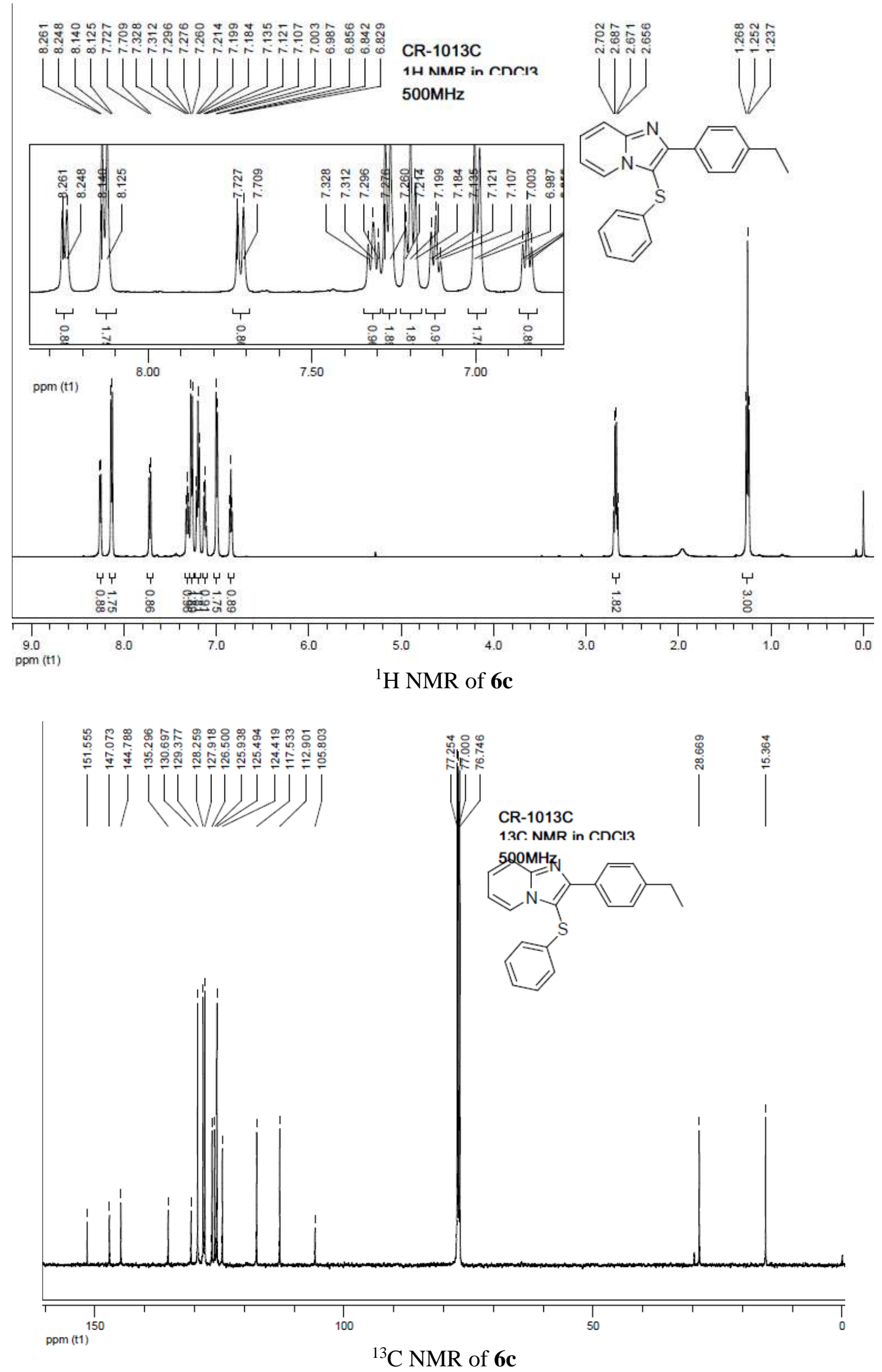


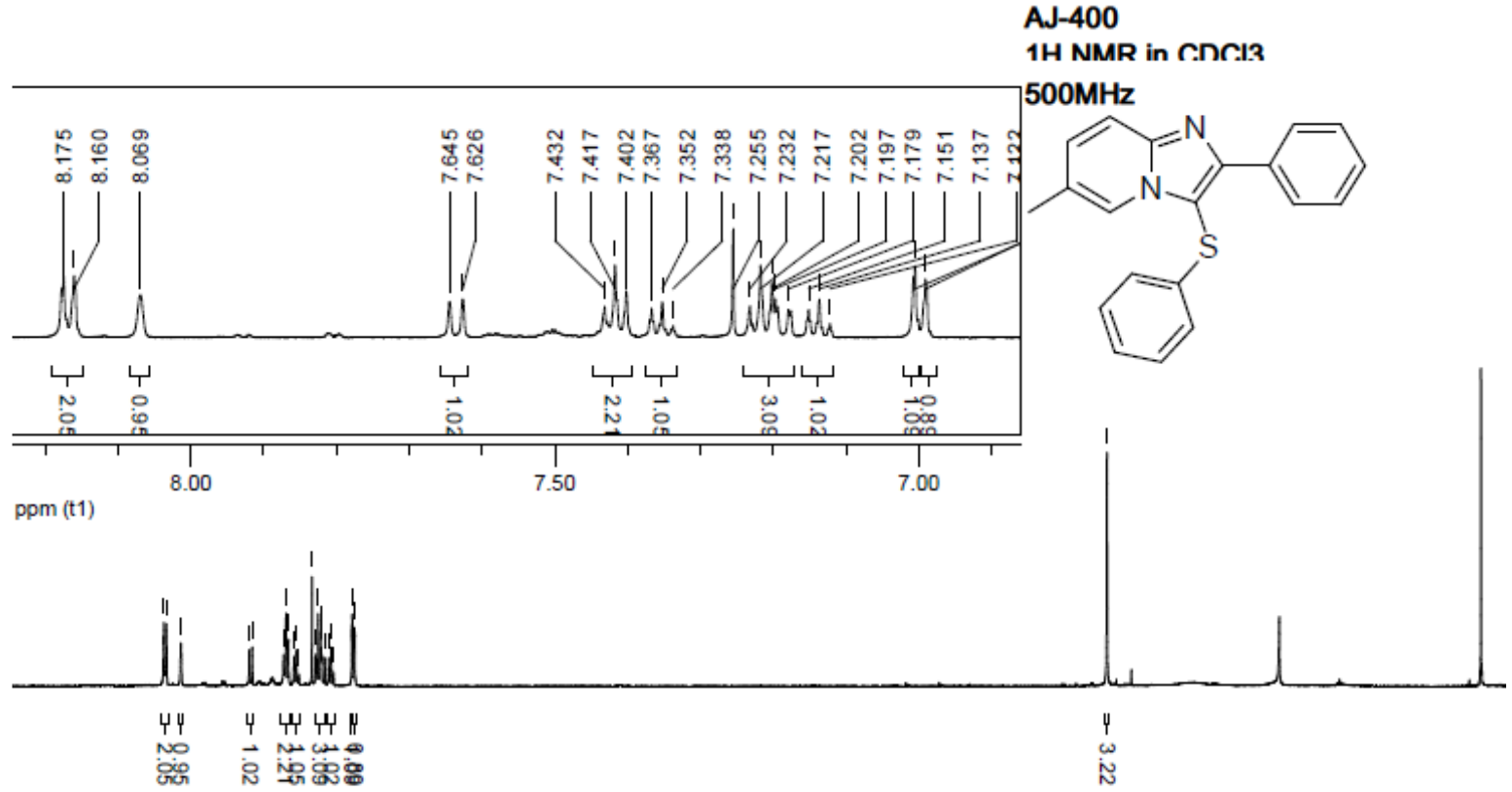

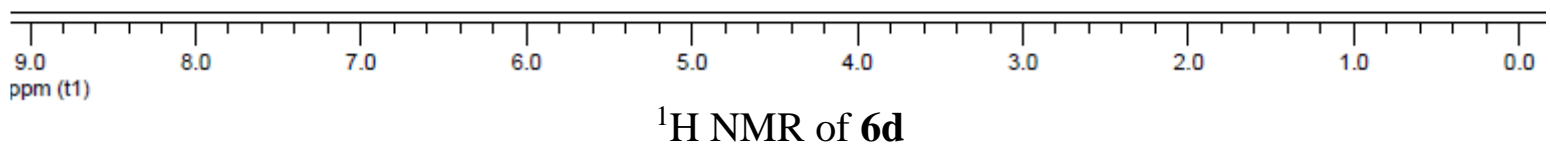

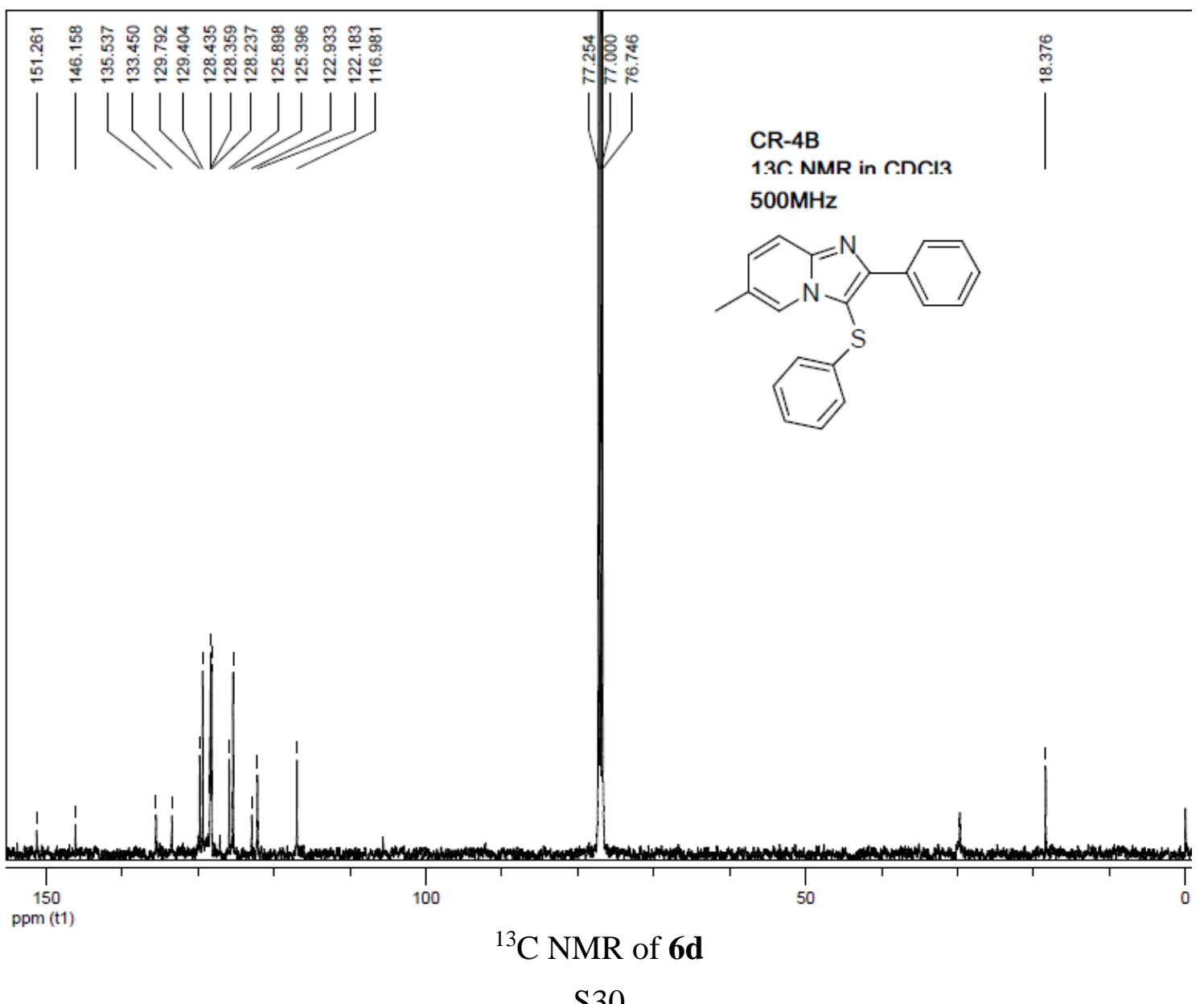




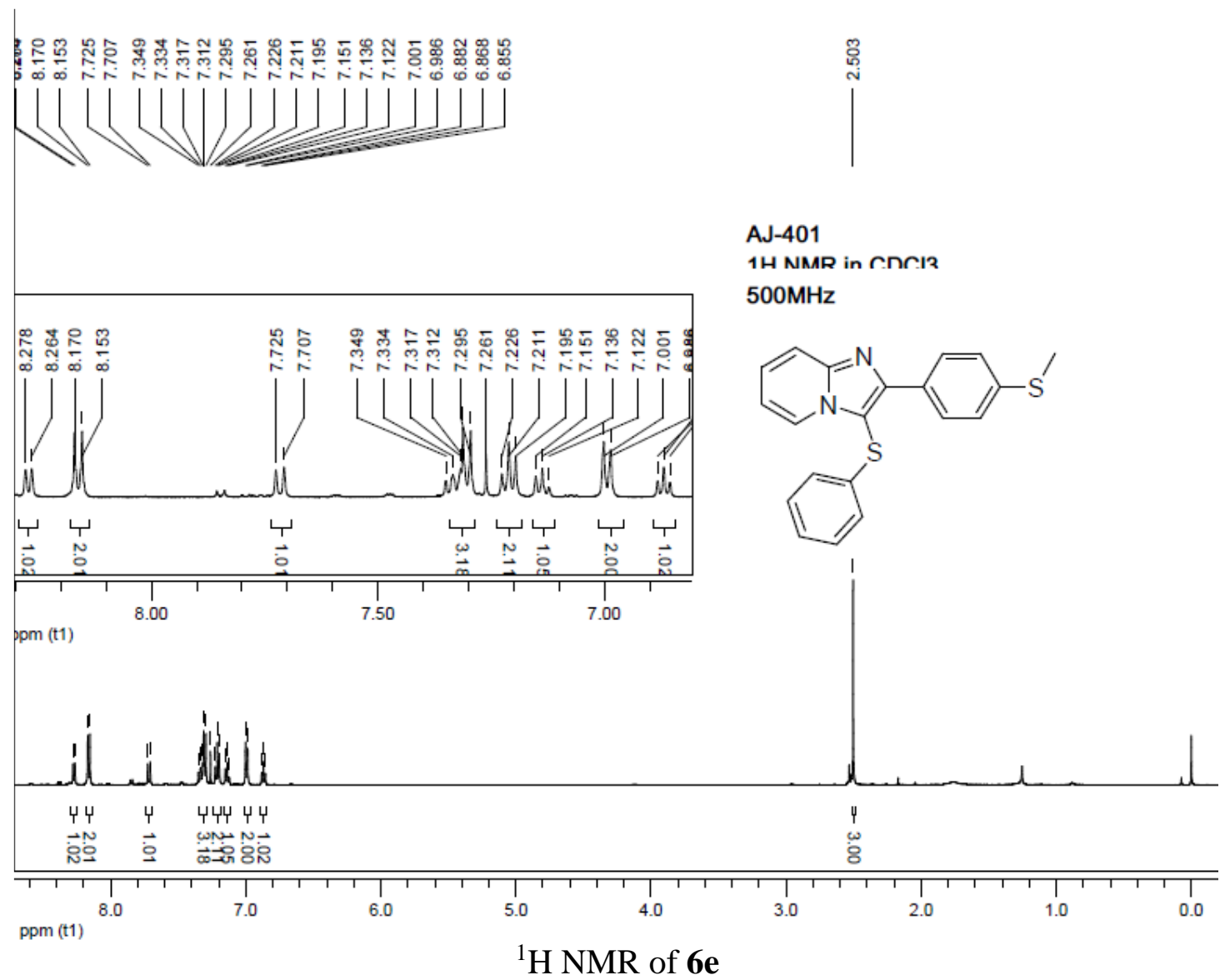

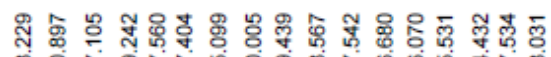

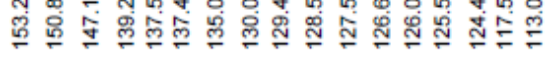

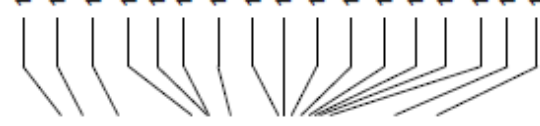

||

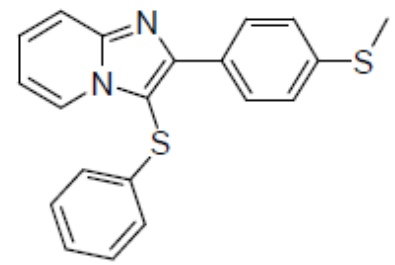

$\frac{\sqrt[5]{2}}{\sqrt[2]{2}}$

AJ-401

1.3C. NMR in C.NC.I3

$500 \mathrm{MHz}$

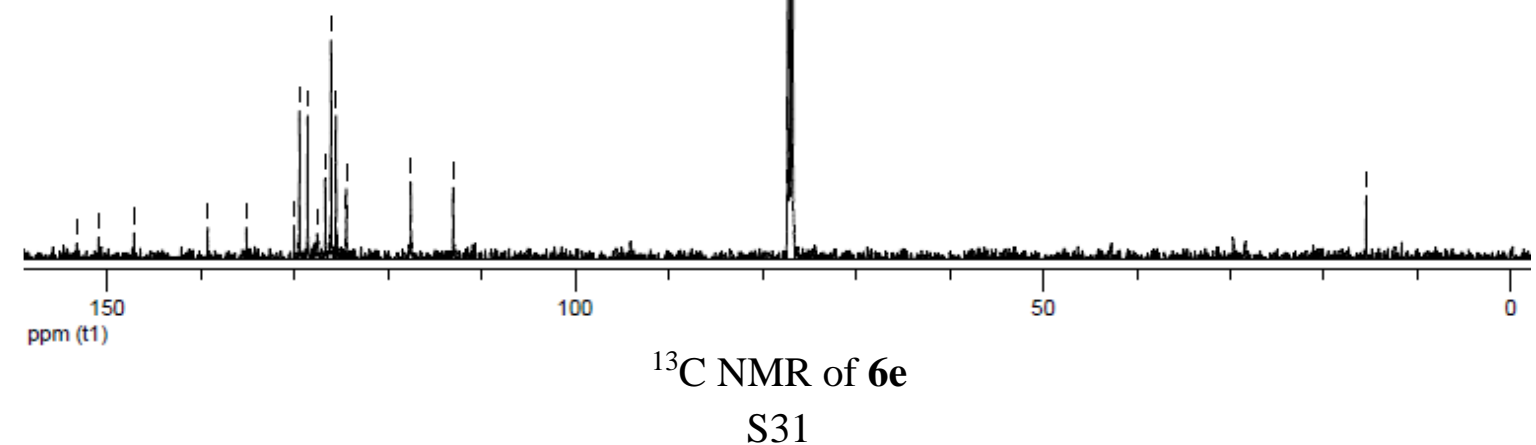



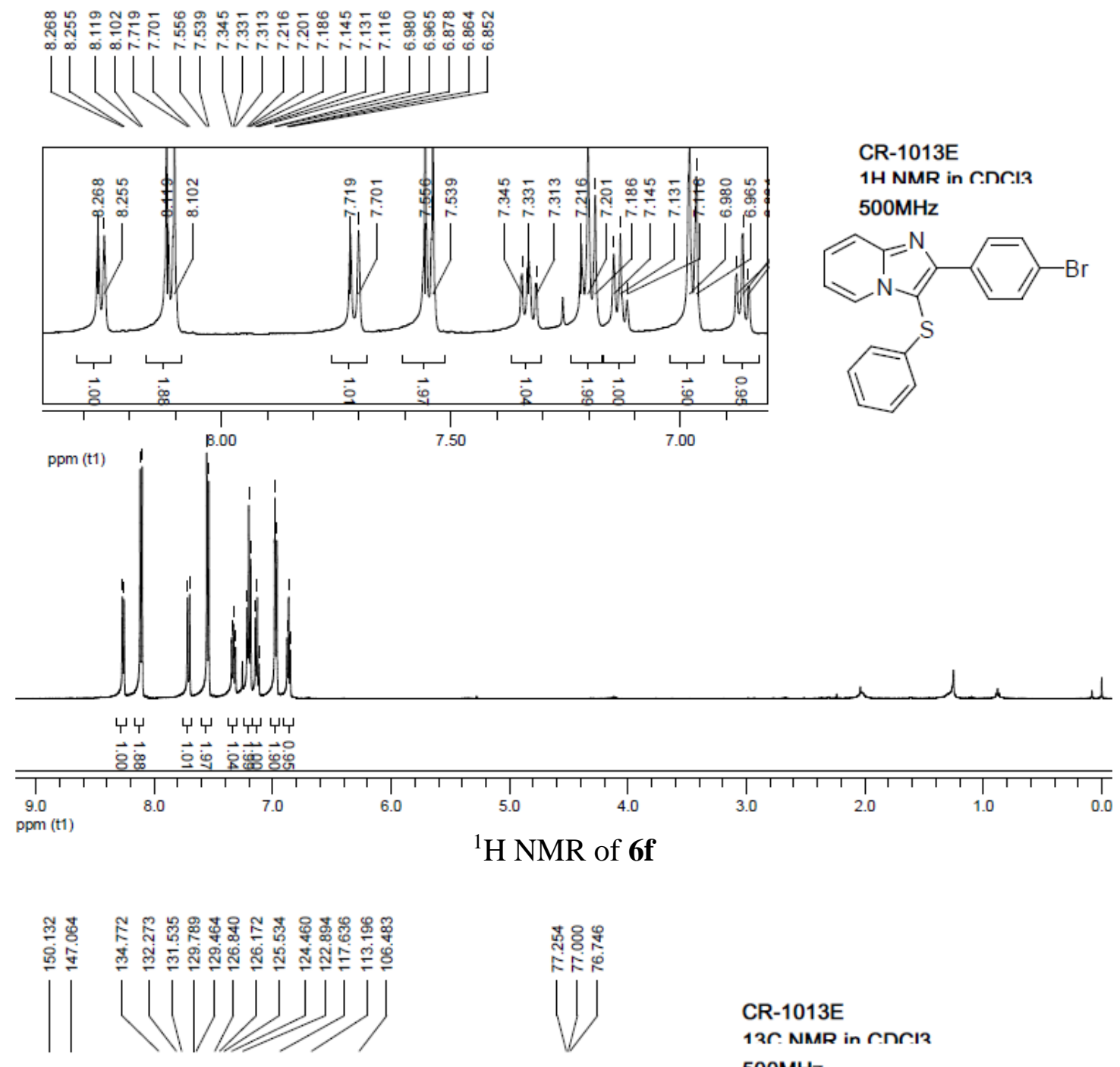

CR-1013E

13C. NAMR in COCII

$500 \mathrm{MHz}$
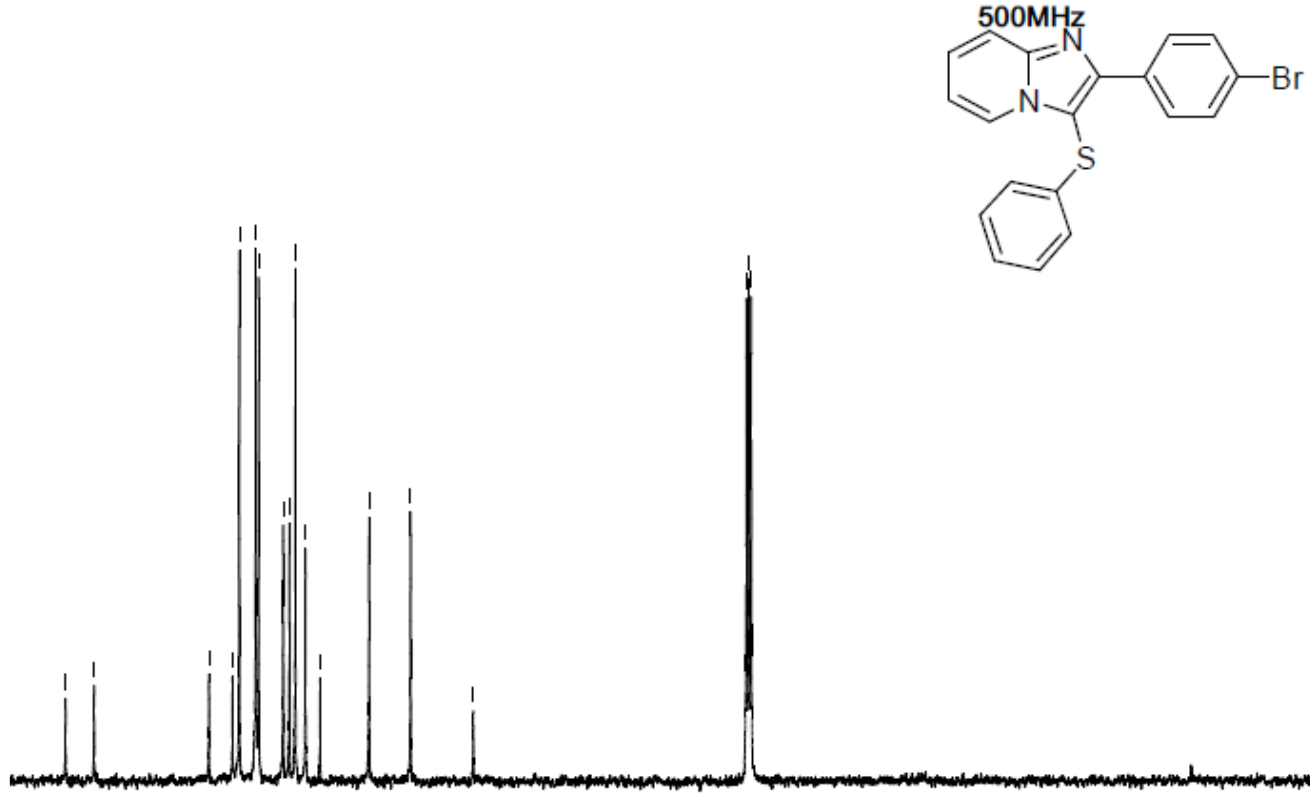

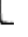




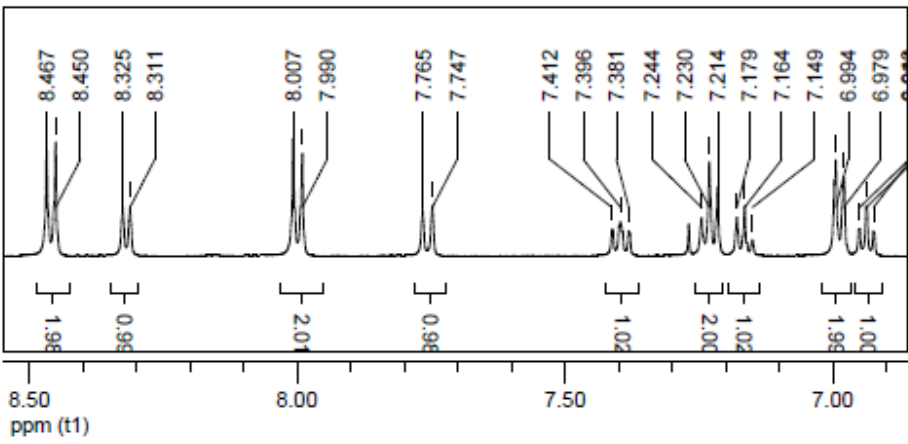

1H NMR in C.NCII

$500 \mathrm{MHz}$
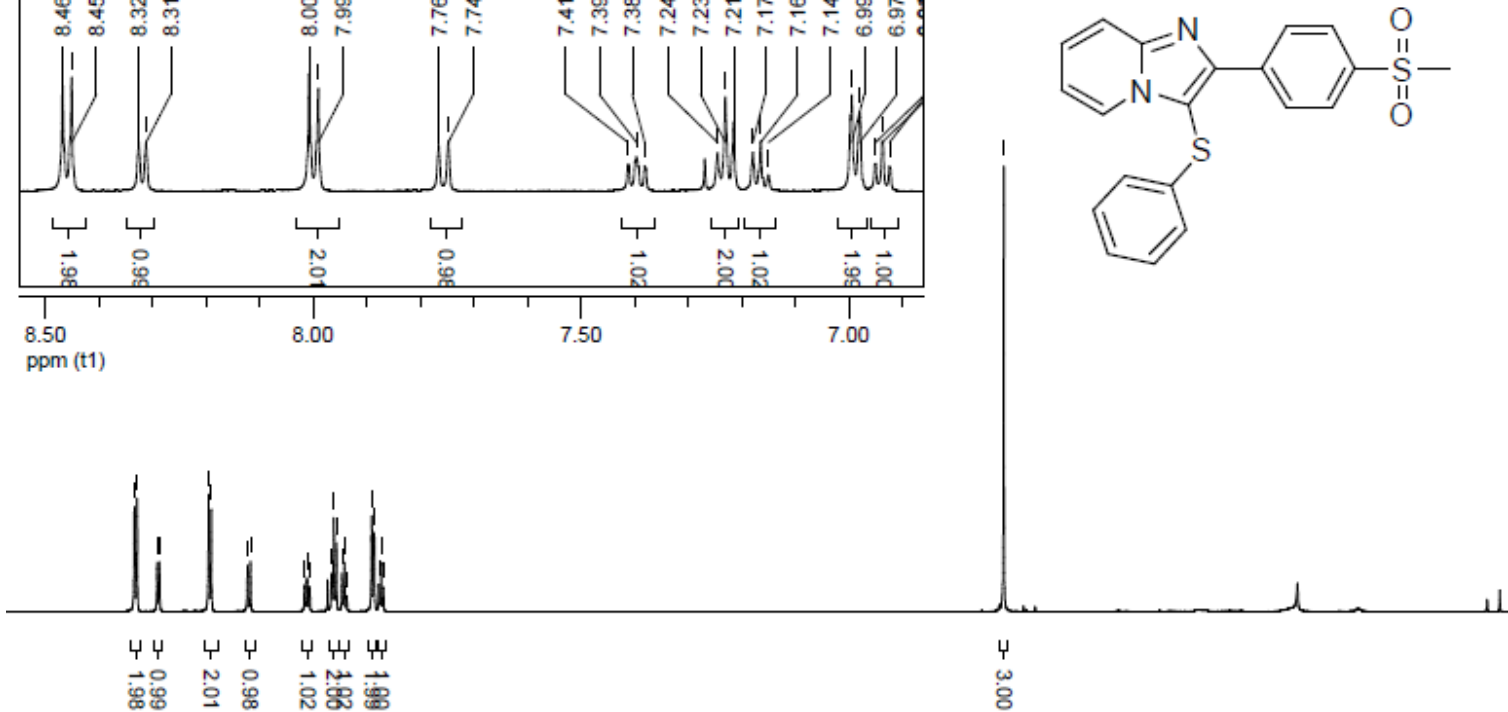

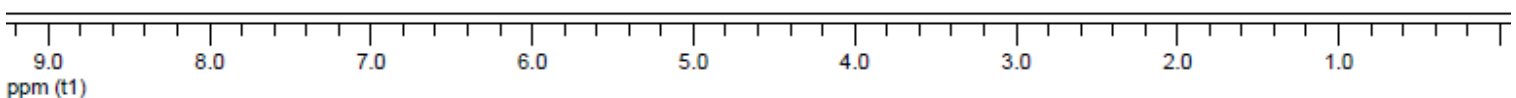

${ }^{1} \mathrm{H}$ NMR of $\mathbf{6 g}$

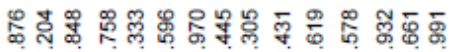

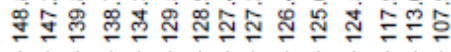
minudedi
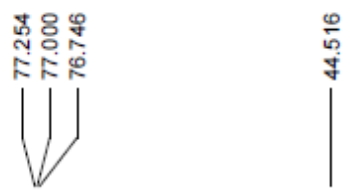

CR-1013F

12S. NMR in C.NCI2 $500 \mathrm{MHz}$

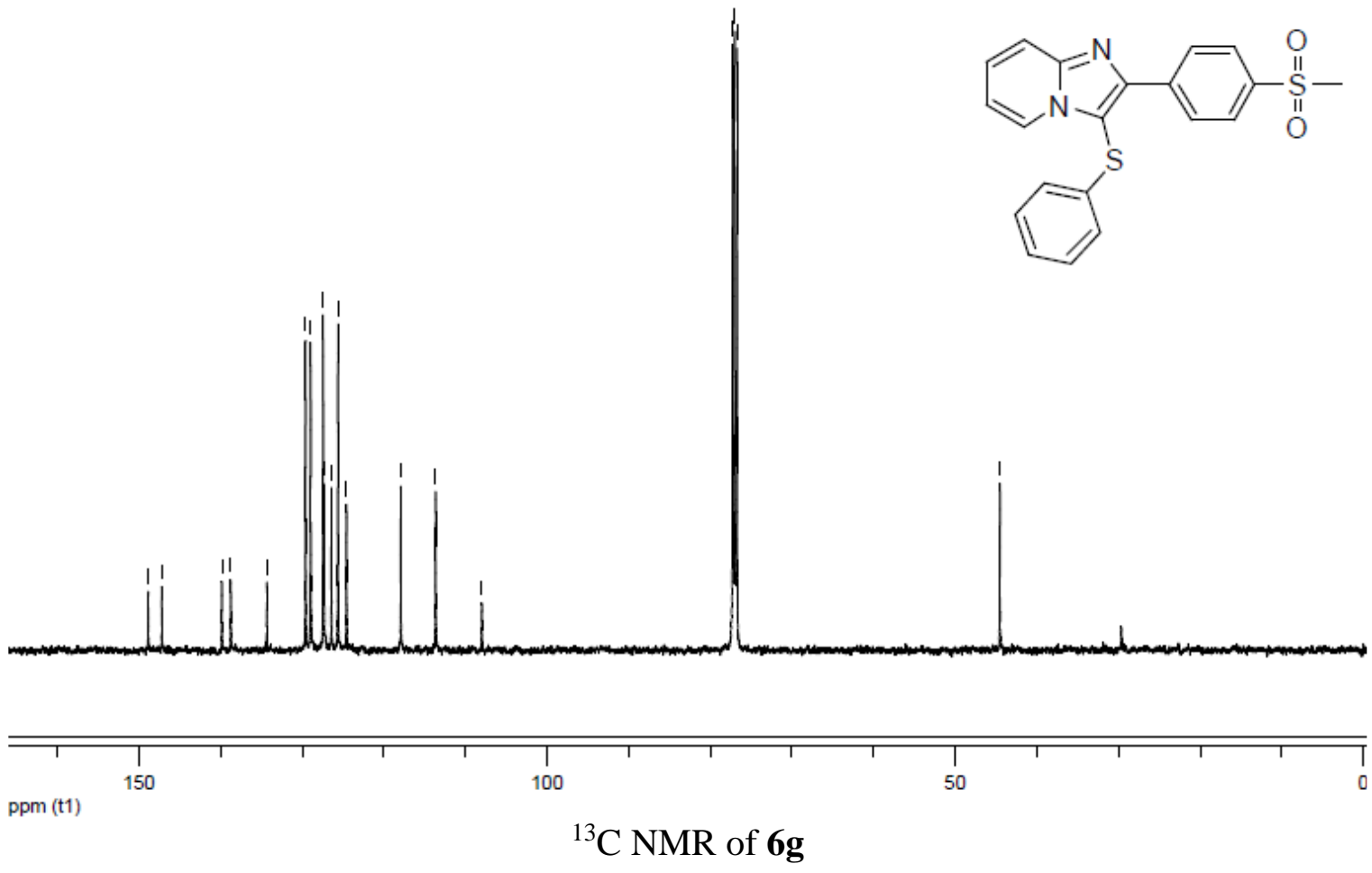




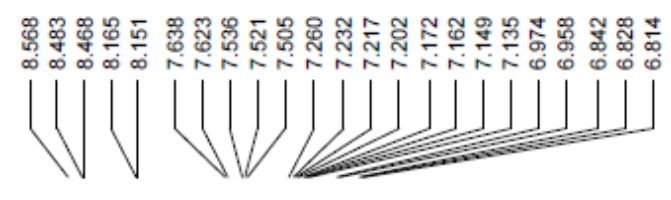

$\left.\right|^{\Sigma}$
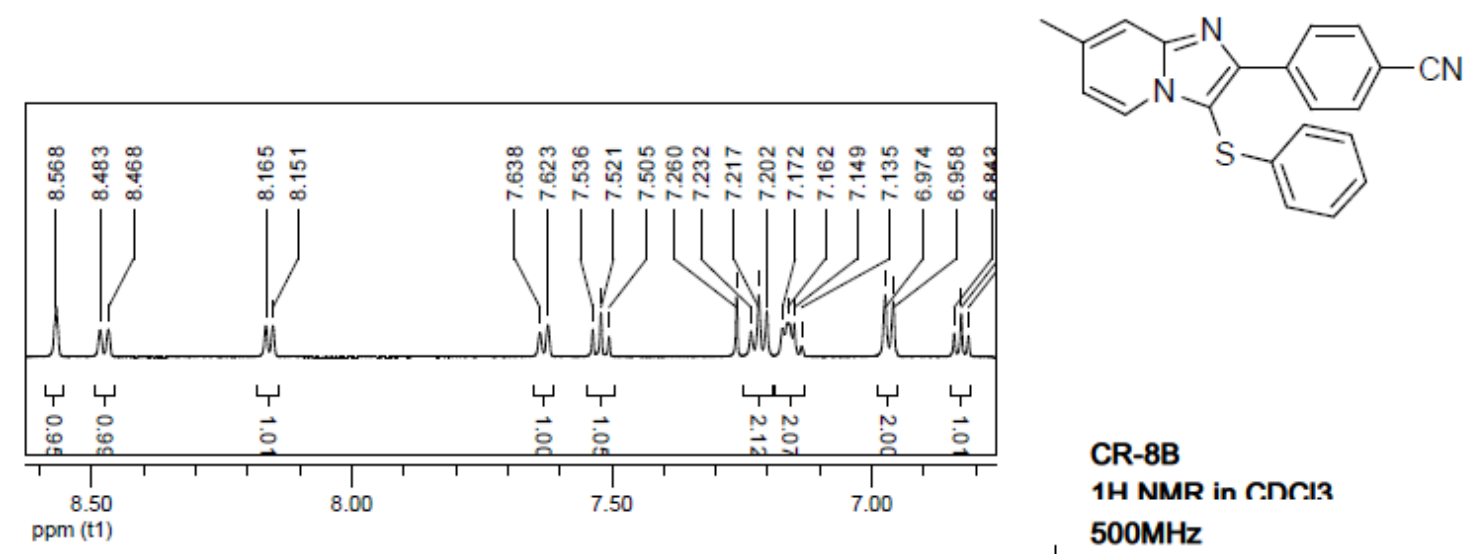

CR-8B

$1 \mathrm{H} \mathrm{NMR}$ in $\mathrm{C}: \mathrm{C}: \mathrm{I3}$

$500 \mathrm{MHz}$

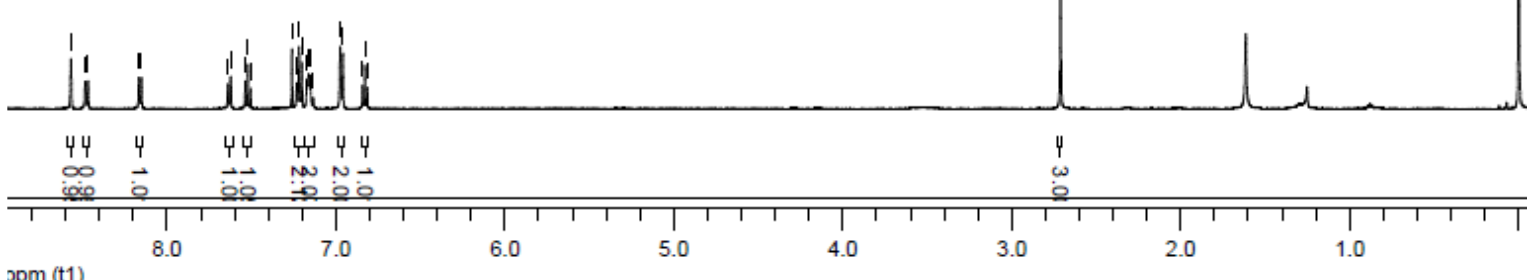

${ }^{1} \mathrm{H}$ NMR of $\mathbf{6 h}$

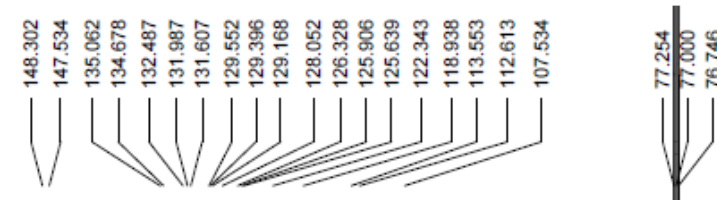

CR-8B

13C. NMR in C.NCII3

$500 \mathrm{MHz}$
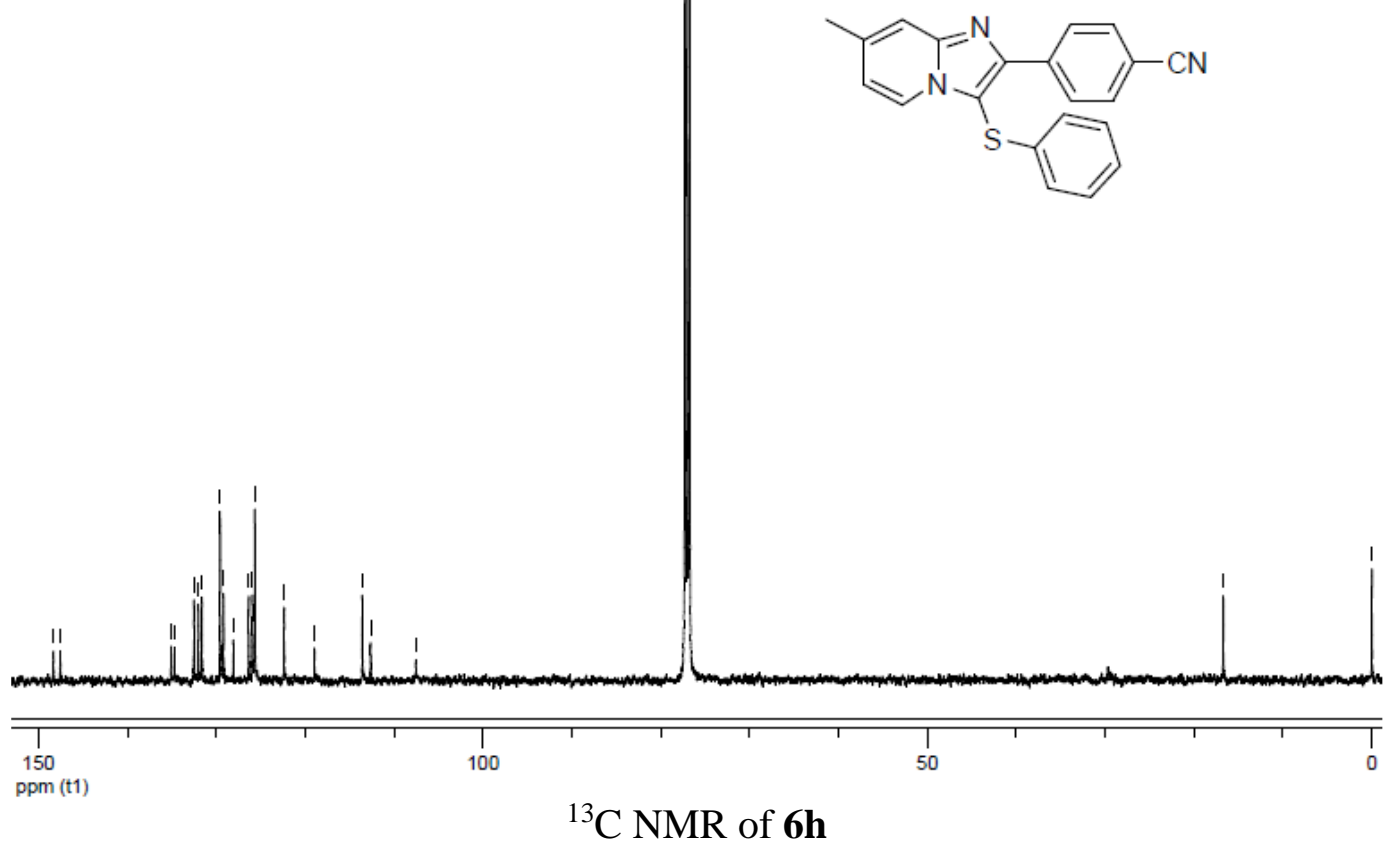


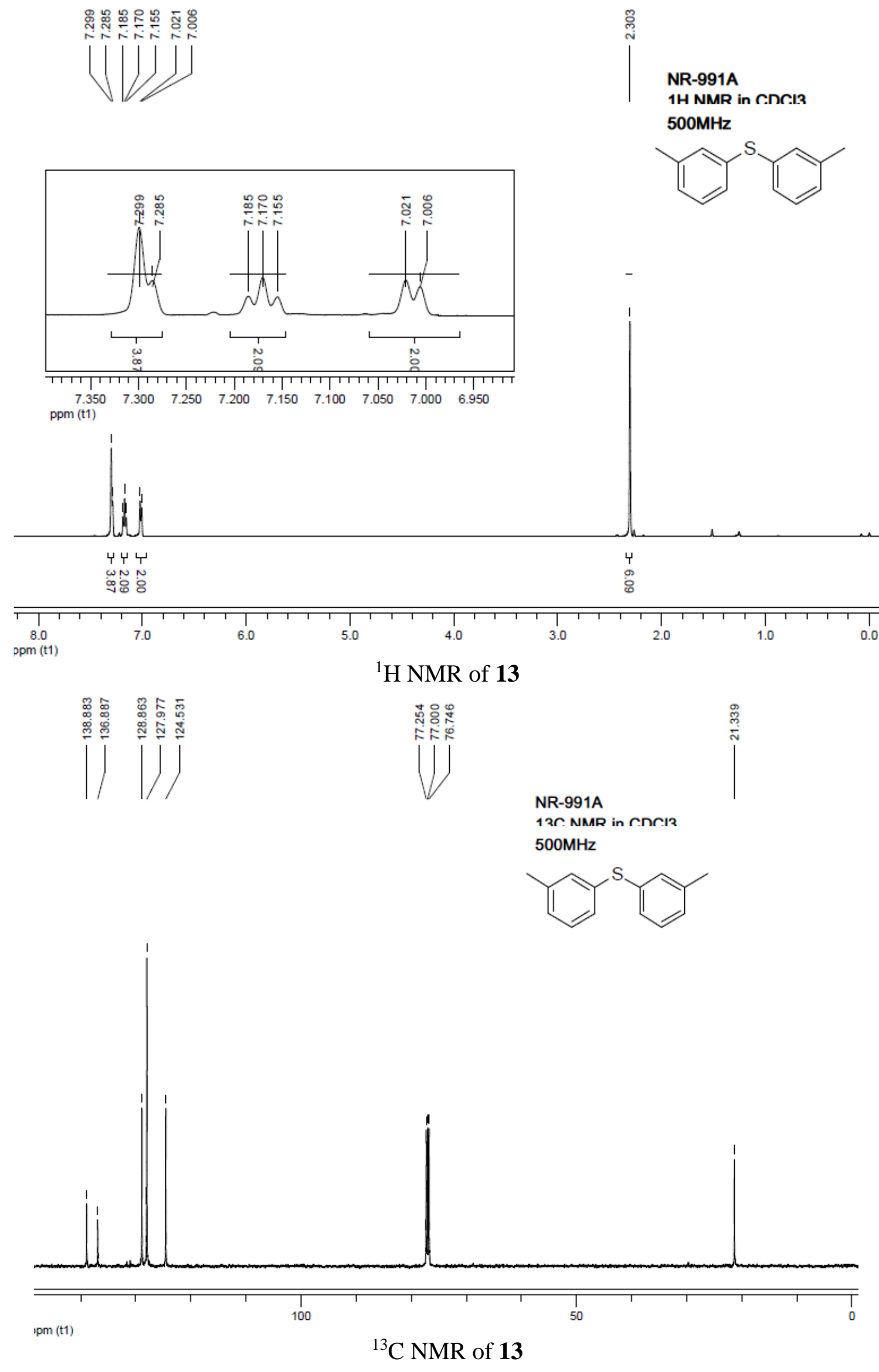




\section{Copies of HRMS spectra}

Elemental Composition Report

Page 1

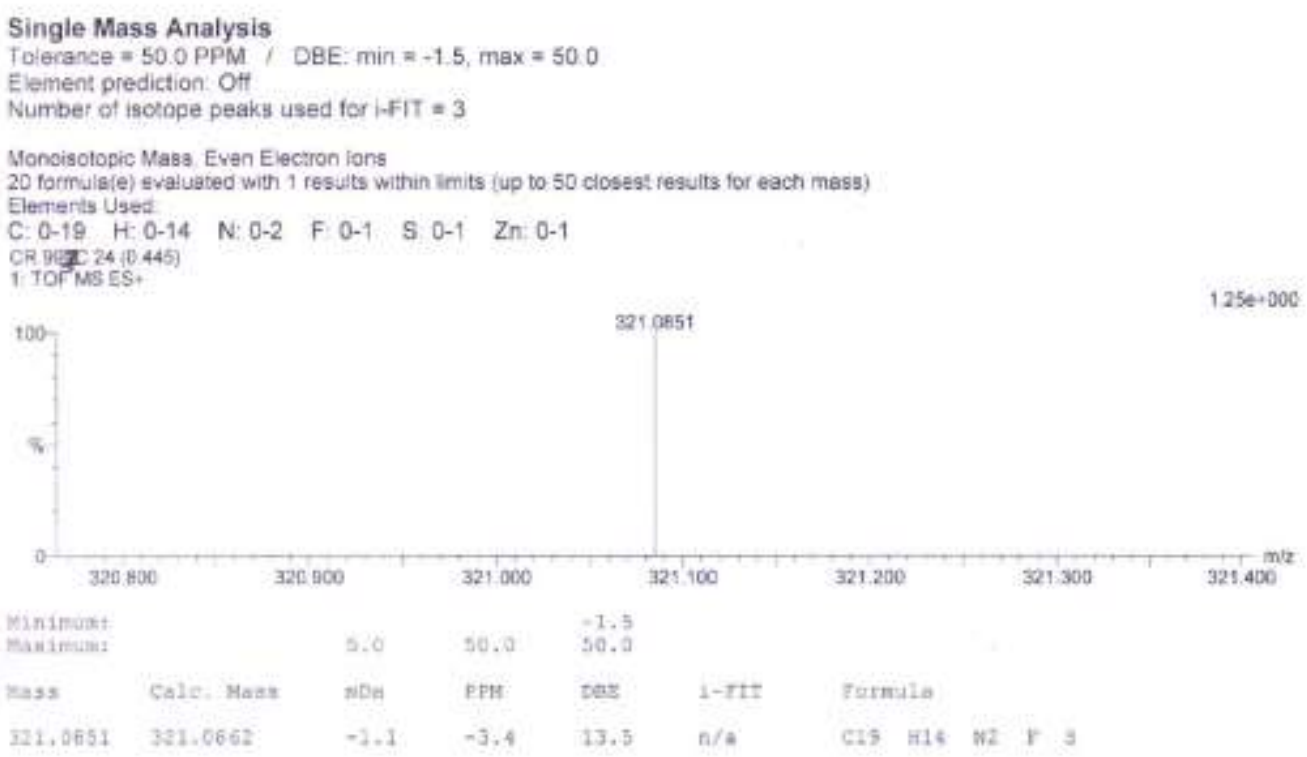

HRMS of $4 c$

Elemental Composition Report

Page 1

\section{Single Mass Analysis}

Tolerance $=50$ O PPM $/$ DBE: $\min =-1.5, \max =50.0$

Element prediction: Off

Number of isctope peaks used for i-FIT $=3$

Monoisotopic Mass, Ever Electron lons

14 formula(e) evaiuated with 1 results within limits fup to 50 closest results for each mass)

Elaments Used

$\begin{array}{lllllll}C: 0.20 & \text { H } 0.14 & \mathrm{~N} & 0.3 & \mathrm{~S}: 0.1 & \mathrm{Z} & \mathrm{n}: 0.1\end{array}$

CR. 15 A $+45(D-834)$

I: TOF MS ES+

$1.40 \mathrm{e}+001$

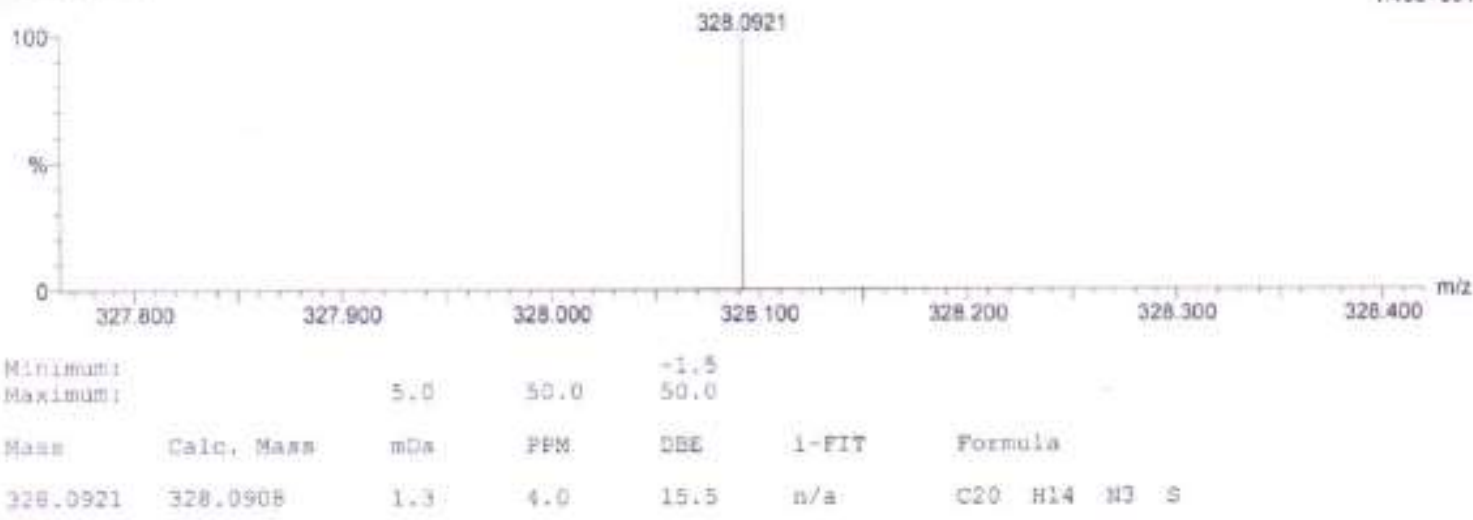

HRMS of 4d 


\section{Single Mass Analysis}

Tolerance $=50.0$ PPM / DBE $\min =-1.5, \max =500$

Element prediction: Off

Number of isotope peaks used for $\mathrm{i}-\mathrm{FIT}=3$

Monoisotopic Mass; Even Electron Ions

13 formula(e) evaluated with 1 results within limits fup to 50 closest results for each mass)

Elements Used

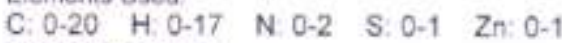

CR 99, A 34 (0.631)

1. TOF MS ESt

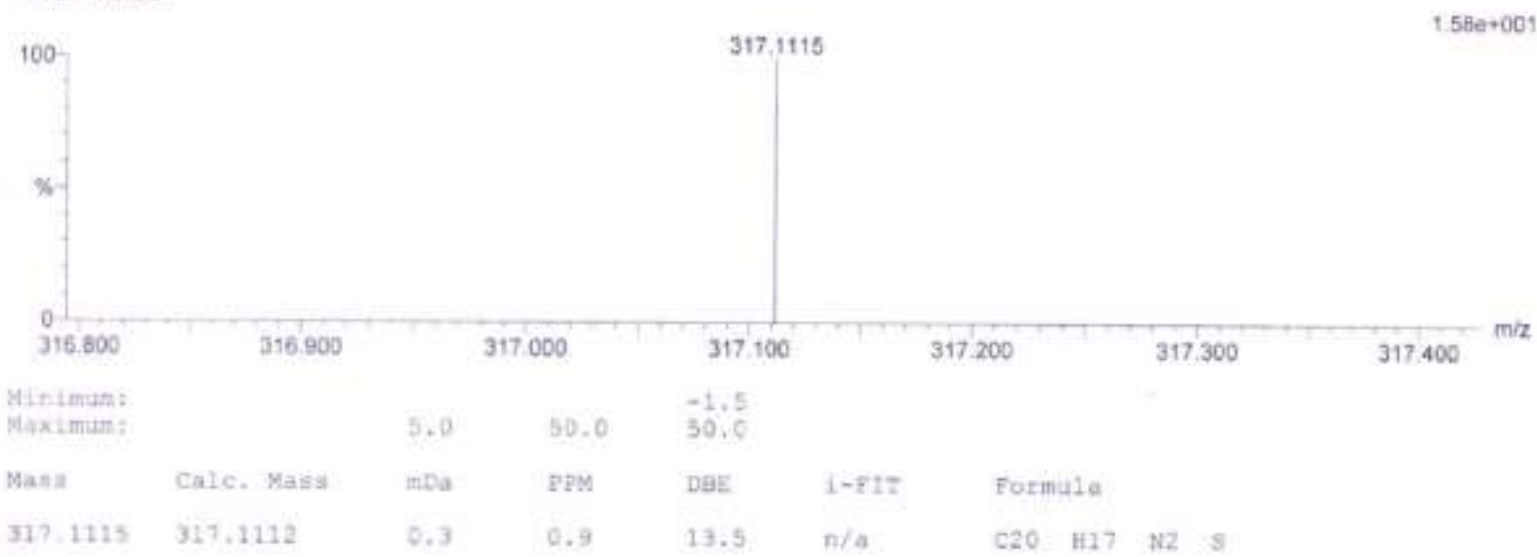

HRMS of $4 \mathrm{i}$

\section{Elemental Composition Report}

\section{Single Mass Analysis}

Tolerance $=50.0 \mathrm{PPM}$; DBE: $\min =-1.5, \max =50.0$

Element prediction: Off

Number of isotope peaks used for i-FIT $=3$

Monoisotopic Mass, Even Electron Ions

3 formulaie) evaluated with 1 results within limits (up to 50 ciosest results for each mass)

Elements Used

$\begin{array}{lllll}\text { C } 0.20 & \text { H: } 0-17 & \text { N: } 0-2 & \text { S: } 0.1\end{array}$

CR 11 B 153 (0 798)

1: TOF MSES.

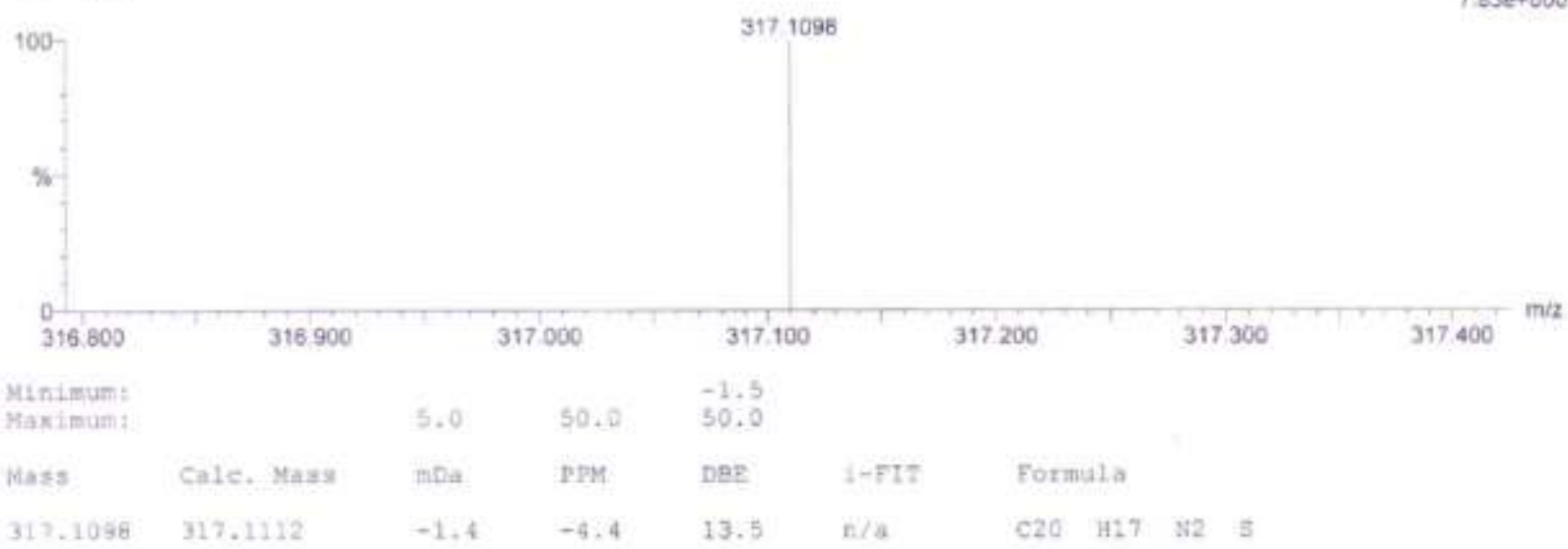

HRMS of $4 j$ 


\section{Single Mass Analysis}

Tolerance $=50.0$ PPM, DBE: $\min =-1.5, \max =50.0$

Element prediction: Off

Number of isotope peaks used for i-FIT $=3$

Monoisotopic Mass Even Electron lons

21 formulaie) evaiuated with 1 results within limits (up to 50 closest results for fach mass)

Elements Used

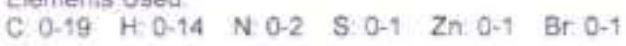

CR 11 C 47 (0.872)

1 TOF MSES.

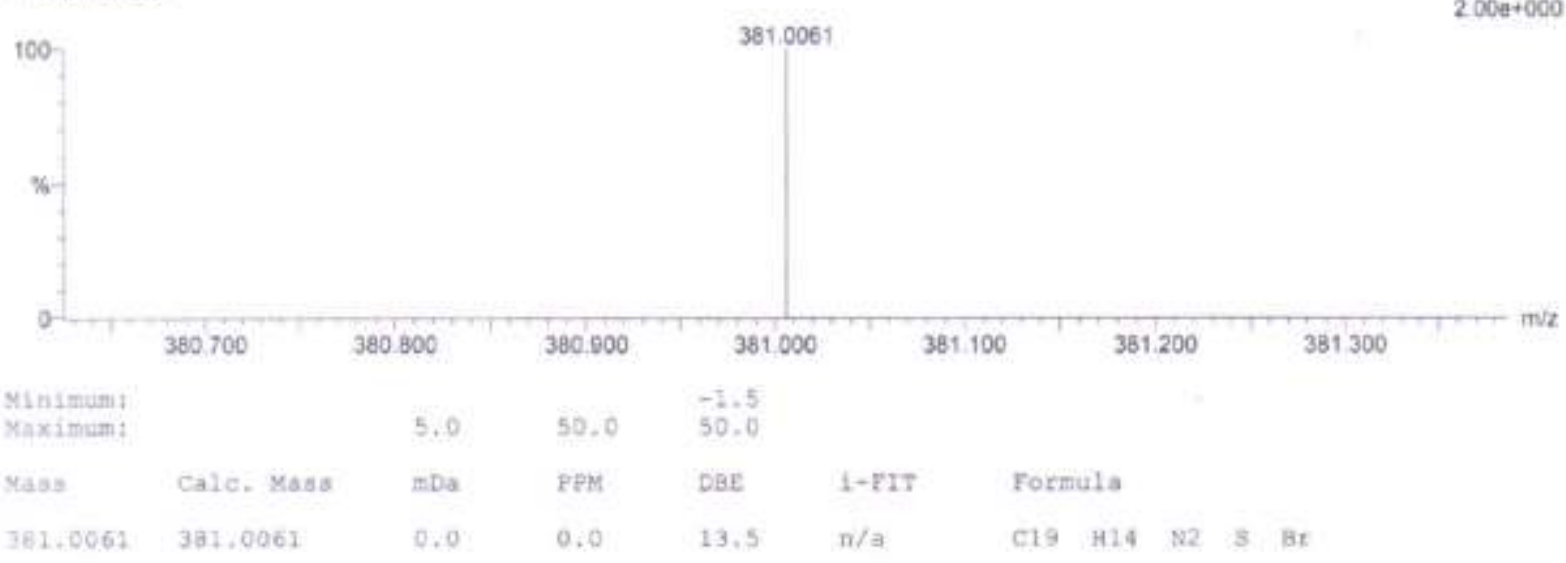

HRMS of $4 \mathrm{k}$

\section{Single Mass Analysis}

Tolerance $=50.0$ PPM / DBE: $\min =-1.5, \max =500$

Element prediction: Off

Number of isotope peaks used for $\mathrm{i}-\mathrm{FIT}=3$

Monoisotopic Mass. Even Electron lons

3 formula(e) evaluated with 1 results within limits (up to 50 closest results for fach mass)

Elements Used:

$\begin{array}{lllll}C: 0.22 & \text { H: } 0-21 & \text { N. } 0-2 & \text { S: } 0-1\end{array}$

CR $10822(0.408)$

1: TOF MS ES.

$1.17 e+002$

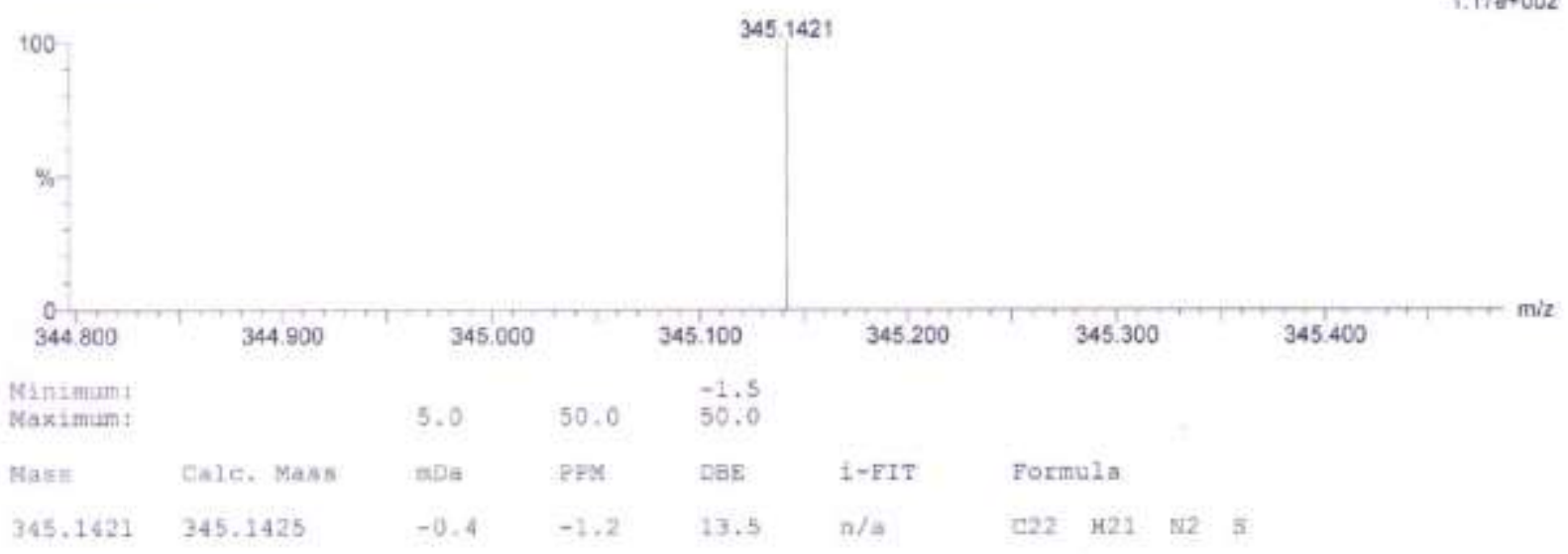

HRMS of 40 


\section{Single Mass Analysis}

Tolerance $=50.0$ PPM $/$ DBE $\min =-1.5, \max =50.0$

Element prediction: Off

Number of isotope peaks used for i-FIT $=3$

Monoisotopic Mass, Even Electron Ions

21 formula(e) evaluated with 1 results within limits (up to 50 elosest results for each mass)

Elements Used

$\begin{array}{llllll}C: 0.21 & \text { H } 0.19 & \text { N } 0-2 & 0: 0.2 & \text { S: } 0.2\end{array}$

CR $3 E 47(0.872)$

1. TOF MSES.

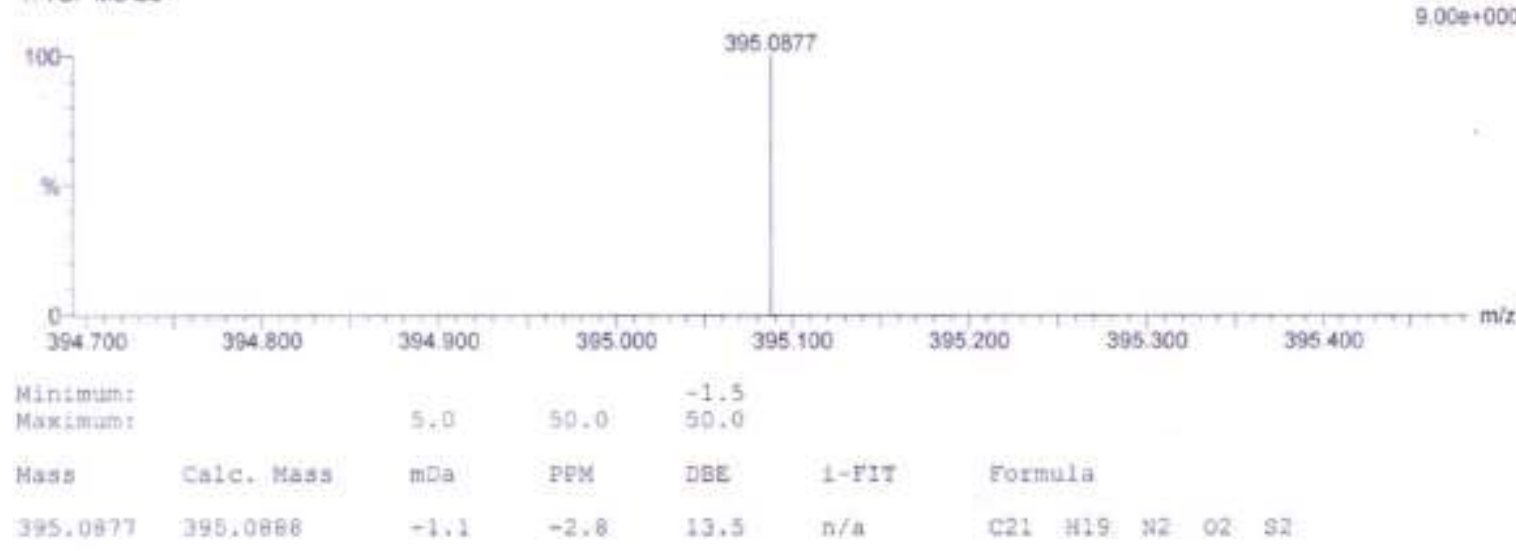

HRMS of $4 \mathrm{~s}$

\section{Single Mass Analysis}

Tolerance $=50.0 \mathrm{PPM} / \mathrm{DBE}: \min =-1.5, \max =50.0$

Element prediction: Off

Number of isotope peaks used for $\mathrm{I}-\mathrm{FIT}=3$

Monoisotopic Mass, Even Electron lons

3 formulare) evaluated with 1 results within limits (up to 50 closest results for each mass)

Elements Used.

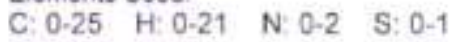

CR BC 28 i0 519 )

1. TOF MSES-

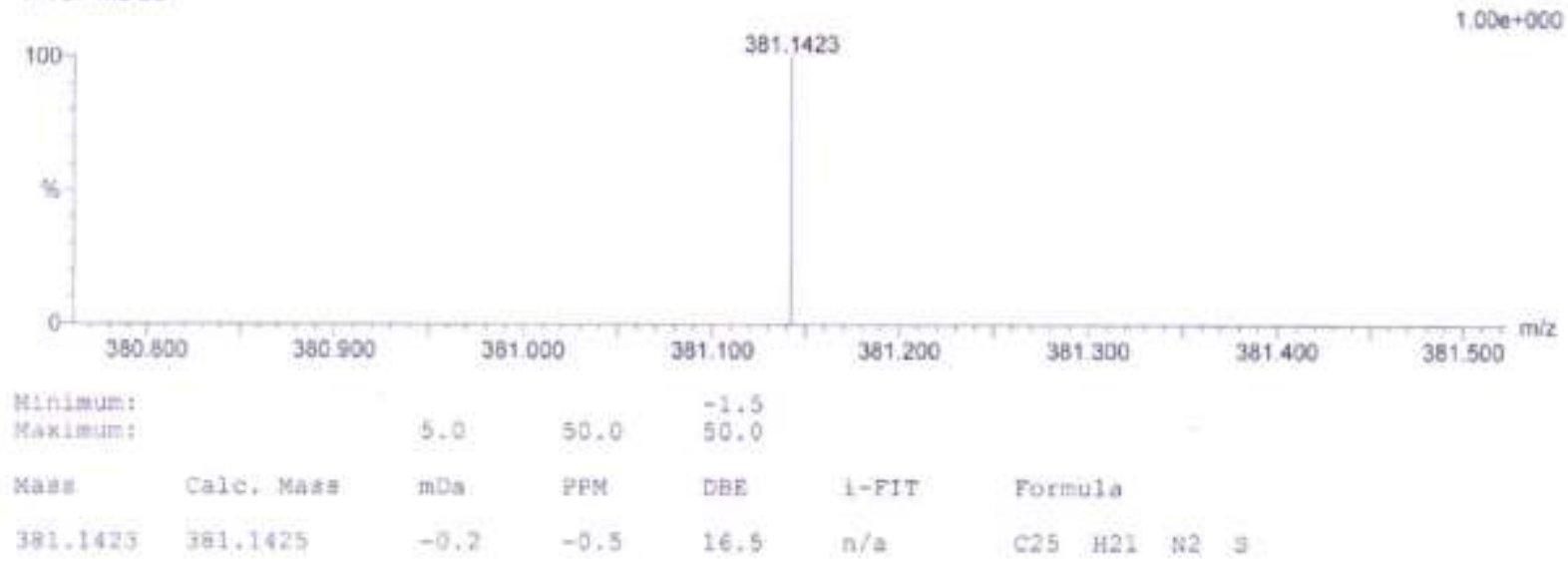

HRMS of $4 u$ 


\section{Single Mass Analysis}

Tolerance $=50.0$ PPM, DBE: $\min =-1.5, \max =50.0$

Element prediction. Off

Number of isotope peaks used for $\mathrm{i}-\mathrm{FIT}=3$

Monoisotopic Mass, Even Electron lons

8 formula(e) evaluated with + results within limits (up to 50 closest results for each mass)

Elements Used
C. $0.24 \quad H: 0.18$
$\mathrm{N}: 0-2 \quad \mathrm{~S}: 0.1 \quad \mathrm{Cl}: 0.1$

CR 8 A $45 \quad 0.035$

1. TOF MS ES+

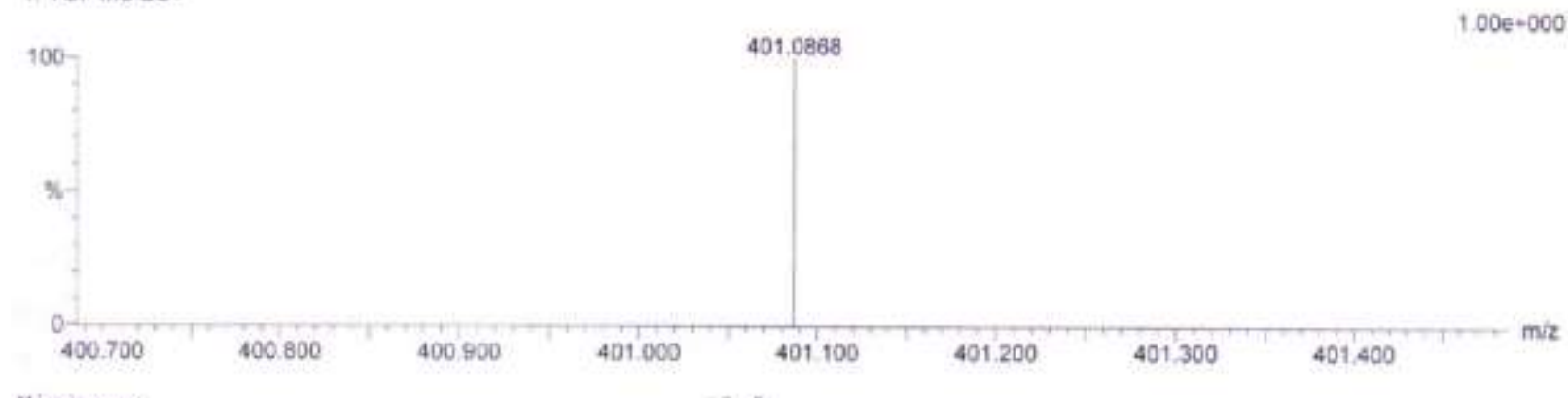

Minimum:

Maximum :

Mass

Cale. Mass

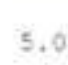

$-1.5$

401,0868

401, 0879

$\mathrm{mba}$

50.0

DeE:

1-FIT

Formula

407.0868

$-1.1$

$-2.7$

16.5

$n / a$

C24 H18 N2 S Cl

HRMS of $4 v$

\section{Elemental Composition Report}

Single Mass Analysis

Tolerance $=50.0$ PPM $/$ DBE $\min =-1.5, \max =50.0$

Element prediction: Off

Number of isotope peaks used for i-FIT $=3$

Manoisotopic Mass, Even Electron Ions

8 formula(e) evaluated with 1 results within limits (up to 50 closest results for each mass)

Elements Used

$\begin{array}{lllllll}C & 0-24 & \text { H. } & 0-18 & \text { N : } 0-2 & \text { S: } 0-1 & \text { Cl: } 0-1\end{array}$

CR $9839(0.724)$

1 TOF MSES+

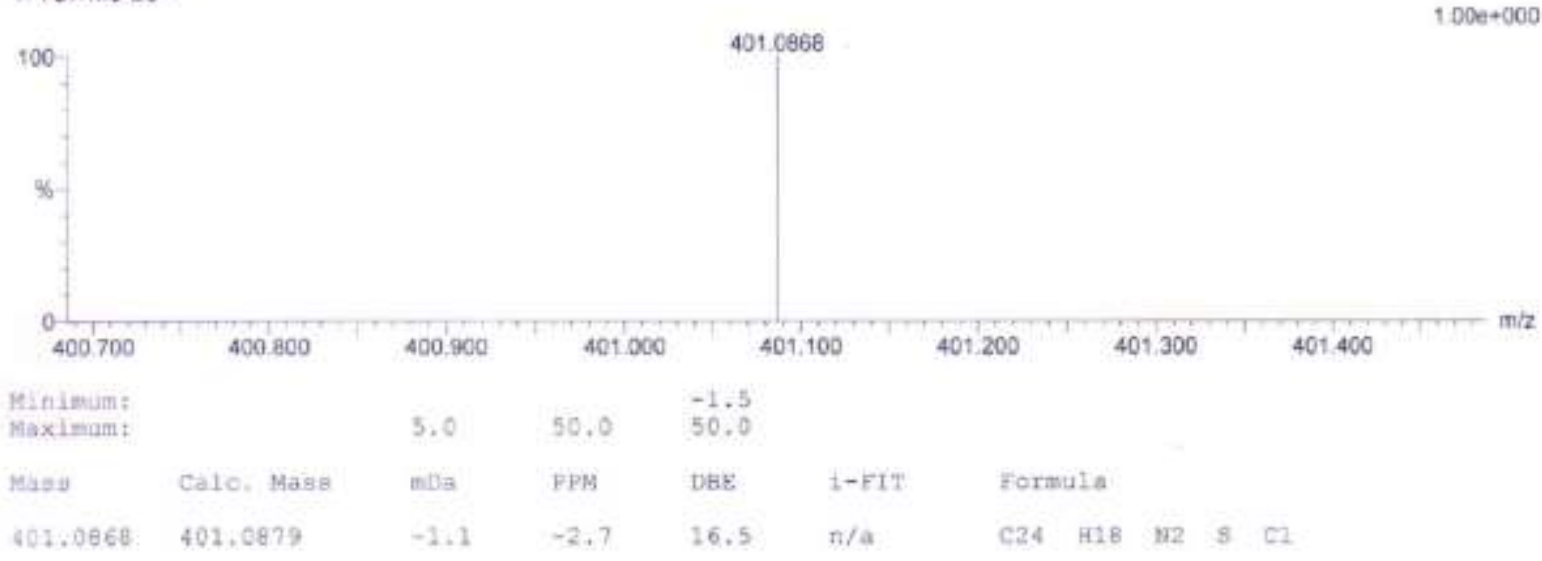

HRMS of $4 w$ 


\section{Single Mass Analysis}

Tolerance $=50.0$ PPM $/$ DBE $\min =-1.5 . \max =50.0$

Element prediction: Off

Number of isotope peaks used for i. FIT $=3$

Monoisotopic Mass, Even Electron lons

23 formula(e) evaluated with 1 results within limits (Up to 50 closest results for each mass)

Elements Used

$\begin{array}{lllllll}C: 0.24 & \text { H } 0.18 & \mathrm{~N}: 0-2 & \text { S: } 0-1 & \text { Zn: } 0.1 & \text { Br: } 0.1\end{array}$

CR 804700.872

1. TCF MS ES+

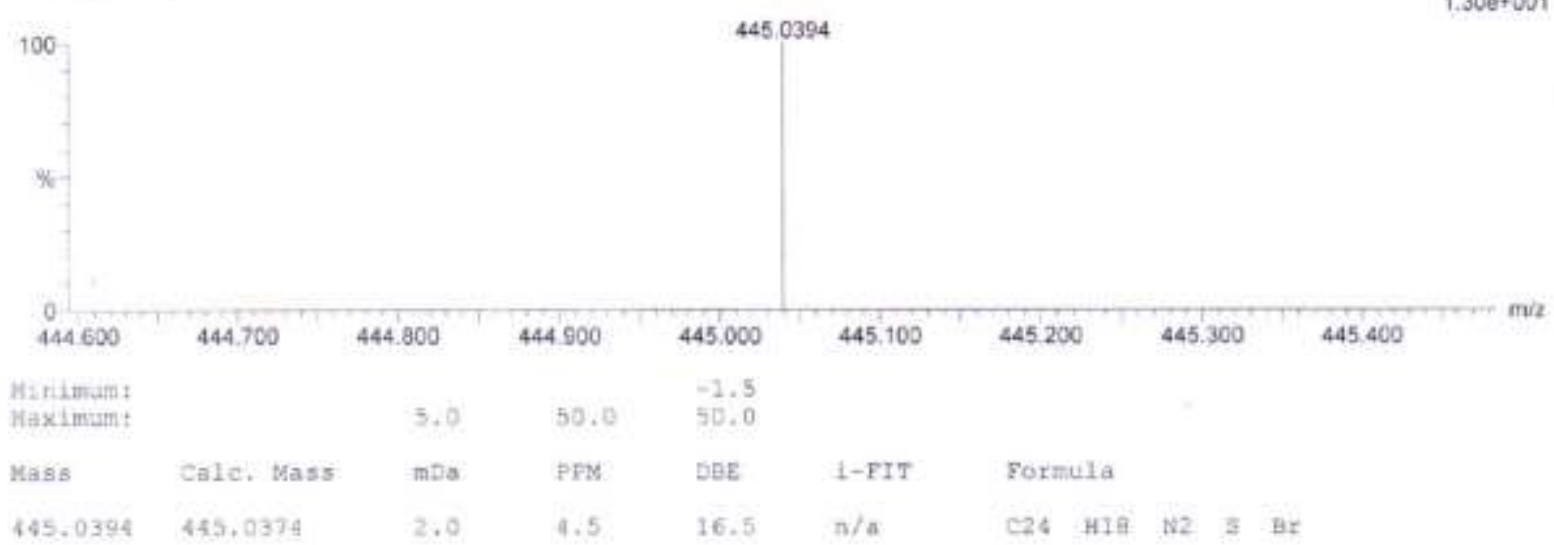

HRMS of $4 x$

\section{Single Mass Analysis}

Tolerance $=50.0$ PPM $\mid$ DBE: $\min =-1.5, \max =50.0$

Element prediction: Off

Number of isotope peaks used for i-FIT $=3$

Monoisotopic Mass Even Electron lons

17 formula(e) evaluated with 1 results within limits (up to 50 closest resuits for each mass)

Elements Used

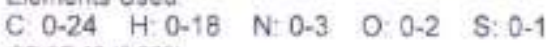

CR $9 E 12(0.223)$

1. TOF MSES.

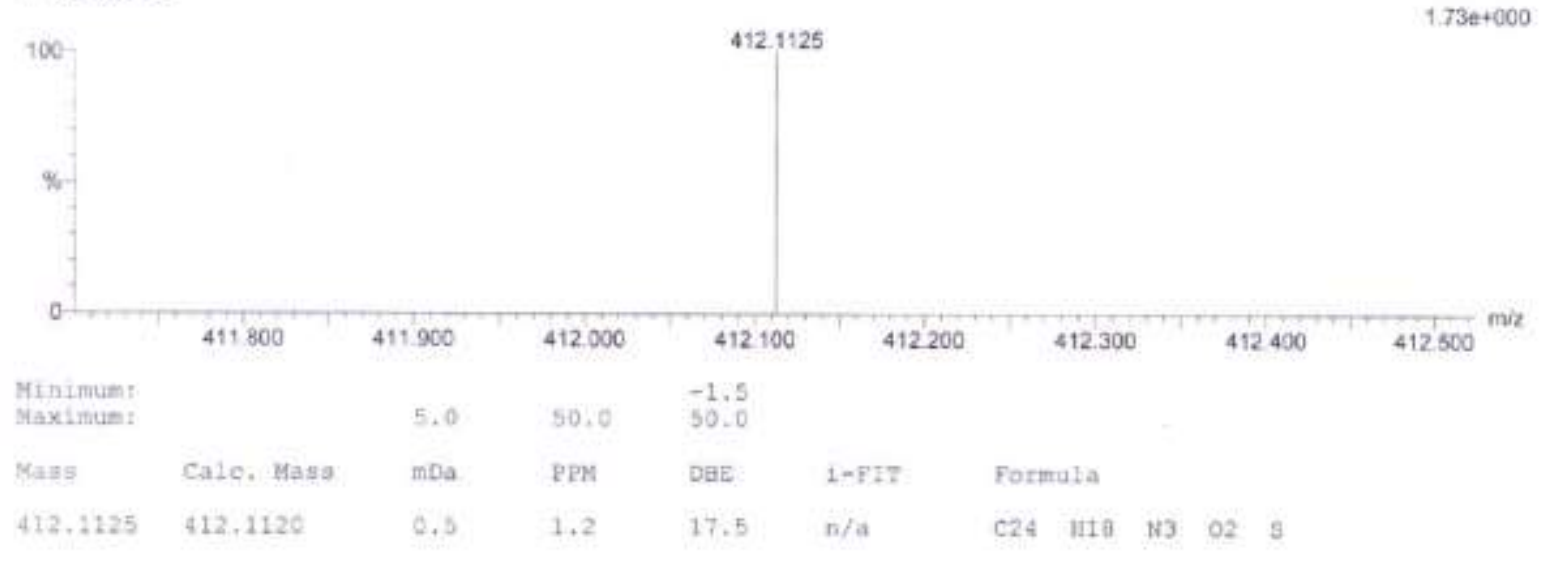

HRMS of $4 y$ 


\section{Single Mass Analysis}

Tolerance $=50.0 \mathrm{PPM}, \mathrm{DBE}: \min =-1.5, \max =50.0$

Element prediction: Off

Number of isotope peaks used for i-FIT $=3$

Monoisotopic Mass, Even Electron Ions

5 formula(e) evaluated with 1 results within limits (up to 50 closest resuits for each mass)

Elements Used
C. $0-18 \quad H: 0-14$
CR-1042D $15(0.278)$

1. TOF MS ES.

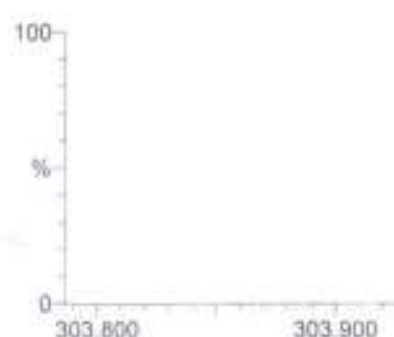

304.0907

303.900

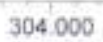

304.100

304.200

304,300

Minimus:

s. $0.50 .0-1.5$

maximats:

Calc. Mass

$\mathrm{mDa}$

PPM

50,0

Mass

$-0.3$

13.5

$1-$ FIT

Formala

$304+0907$

$-0,1$

$\mathrm{n} / \mathrm{a}$

Cle HI4 N3 s

HRMS of $4 z$

\section{Elemental Composition Report}

\section{Single Mass Analysis}

Tolerance $=50.0$ PPM $\&$ DBE: $\min =-1.5, \max =50.0$

Element prediction. Off

Number of isotope peaks used for $\mathrm{F}-\mathrm{FiT}=3$

Monoisotopic Mass, Even Electron Ions

5 formula(e) evaluated with 1 results within limits (up to 50 ciosest results for each mass)

Elements Used:

$\begin{array}{llll}\text { C. } 0-21 & \text { H. } 0-16 & \text { N: } 0-3 & \text { S: } 0-1\end{array}$

CR $8046(0.053)$

1: TOF MSES+

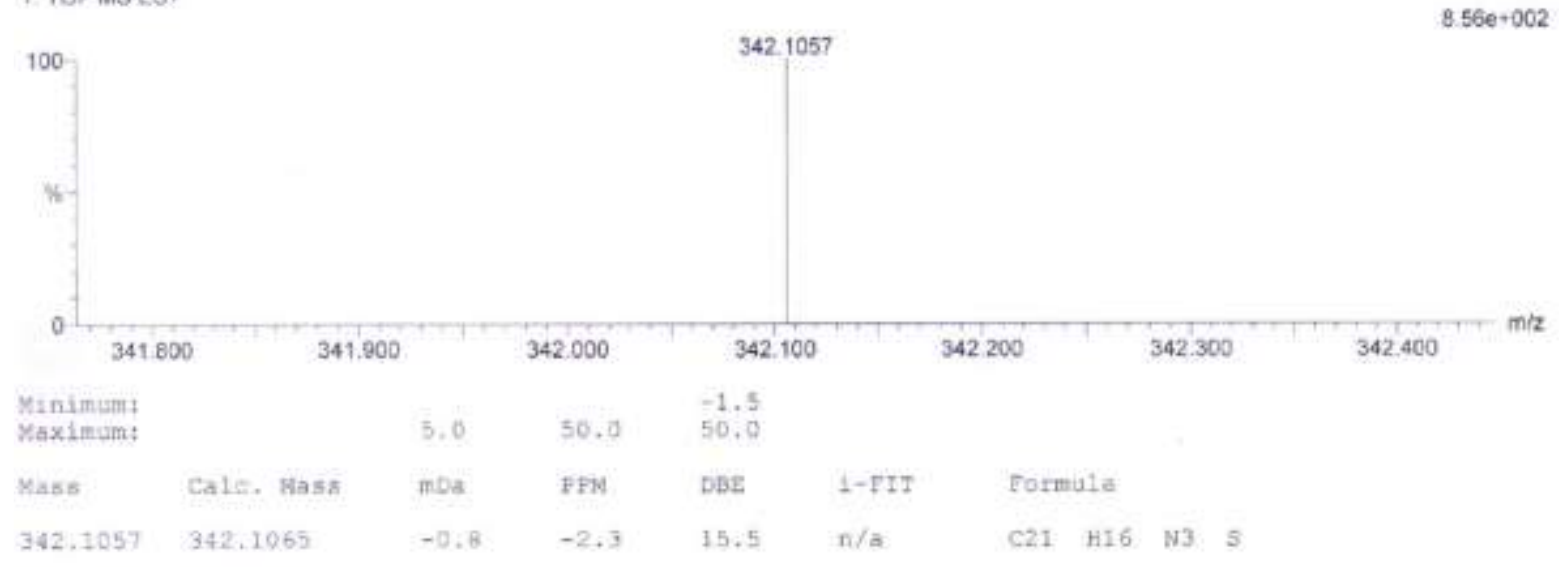

HRMS of $6 \mathrm{~h}$ 